\title{
Phanerozoic geological evolution of Northern and Central Africa: An overview
}

\author{
R. Guiraud ${ }^{\mathrm{a}, *}$, W. Bosworth ${ }^{\mathrm{b}}$, J. Thierry ${ }^{\mathrm{c}}$, A. Delplanque ${ }^{\text {a }}$ \\ ${ }^{a}$ Laboratoire Dynamique de la Lithosphère, Case 60, Université Montpellier II, 34095 Montpellier Cedex 5, France

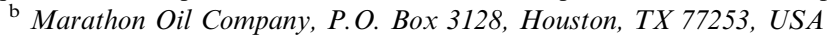 \\ ${ }^{\mathrm{c}}$ Centre des Sciences de la Terre, Université de Bourgogne, 6 Brd Gabriel, 21000 Dijon, France
}

\begin{abstract}
The principal paleogeographic characteristics of North and Central Africa during the Paleozoic were the permanency of large exposed lands over central Africa, surrounded by northerly and northwesterly dipping pediplanes episodically flooded by epicontinental seas related to the Paleotethys Ocean. The intra-continental Congo-Zaire Basin was also a long-lived feature, as well as the Somali Basin from Late Carboniferous times, in conjunction with the development of the Karoo basins of southern Africa. This configuration, in combination with eustatic sea-level fluctuations, had a strong influence on facies distributions. Significant transgressions occurred during the Early Cambrian, Tremadocian, Llandovery, Middle to Late Devonian, Early Carboniferous, and Moscovian.

The Paleozoic tectonic history shows an alternation of long periods of predominantly gentle basin subsidence and short periods of gentle folding and occasionally basin inversion. Some local rift basins developed episodically, located mainly along the northern African-Arabian plate margin and near the West African Craton/Pan-African Belt suture. Several arches or spurs, mainly N-S to NESW trending and inherited from late Pan-African fault swarms, played an important role. The Nubia Province was the site of numerous alkaline anorogenic intrusions, starting in Ordovician times, and subsequently formed a large swell.

Paleozoic compressional events occurred in the latest Early Cambrian ("Iskelian"), Medial Ordovician to earliest Silurian ("pre-Caradoc" and "Taconian"), the end Silurian ("Early Acadian" or "Ardennian"), mid-Devonian ("Mid-Acadian"), the end Devonian ("Late Acadian" or "Bretonnian"), the earliest Serpukhovian ("Sudetic"), and the latest Carboniferous-earliest Permian ("Alleghanian" or "Asturian"). The strongest deformations, including folding, thrusting, and active strike-slip faulting, were registered in Northwestern Africa during the last stage of the Pan-African Belt development around the West African Craton (end Early Cambrian) and during the polyphased Hercynian-Variscan Orogeny that extended the final closure of the Paleotethys Ocean and resulted in the formation of the Maghrebian and Mauritanides belts. Only gentle deformation affected central and northeastern African during the Paleozoic, the latter remaining a passive margin of the Paleotethys Ocean up to the Early Permian when the development of the Neotethys initiated along the Eastern Mediterranean Basins.

The Mesozoic-Cenozoic sedimentary sequence similarly consists of a succession of eustatically and tectonically controlled depositional cycles. Through time, progressive southwards shift of the basin margins occurred, related to the opening of the Neotethys Ocean and to the transgressions resulting from warming of the global climate and associated rise of the global sea level. The Guinean-Nigerian Shield, the Hoggar, Tibesti-Central Cyrenaica, Nubia, western Saudi Arabia, Central African Republic, and other long-lived arches delimited the principal basins. The main tectonic events were the polyphased extension, inversion, and folding of the northern African-Arabian shelf margin resulting in the development of the Alpine Maghrebian and Syrian Arc belts, rifting and drifting along the Central Atlantic, Somali Basins, and Gulf of Aden-Red Sea domains, inversion of the Murzuq-Djado Basin, and rifting and partial inversion along the Central African Rift System.

Two major compressional events occurred in the Late Santonian and early Late Eocene. The former entailed folding and strike-slip faulting along the northeastern African-northern Arabian margin (Syrian Arc) and the Central African Fold Belt System (from Benue to Ogaden), and thrusting in Oman. The latter ("Pyrenean-Atlasic") resulted in folding, thrusting, and local metamorphism of the northern
\end{abstract}

\footnotetext{
* Corresponding author. Tel.: +334671446 14; fax: +33467143642.

E-mail address: guiraud@dstu.univ-montp2.fr (R. Guiraud).
} 
African-Arabian plate margin, and rejuvenation of intra-plate fault zones. Minor or more localized compressional deformations took place in the end Cretaceous, the Burdigalian, the Tortonian and Early Quaternary. Recent tectonic activity is mainly concentrated along the Maghrebian Alpine Belt, the offshore Nile Delta, the Red Sea-East African Rifts Province, the Aqaba-Dead Sea-Bekaa sinistral strike-slip fault zone, and some major intra-plate fault zones including the Guinean-Nubian, Aswa, and central Sinai lineaments.

Large, long-lived magmatic provinces developed in the Egypt-Sudan confines (Nubia), in the Hoggar-Air massifs, along the Cameroon Line and Nigerian Jos Plateau, and along the Levant margin, resulting in uplifts that influenced the paleogeography. Extensive tholeiitic basaltic magmatism at $\sim 200$ Ma preceded continental break-up in the Central Atlantic domain, while extensive alkaline to transitional basaltic magmatism accompanied the Oligocene to Recent rifting along the Red Sea-Gulf of Aden-East African rift province.

Keywords: Phanerozoic; Paleogeography; Tectonics; Rifting; Inversion; Magmatism; Northern Africa; Western Africa; Central Africa; Northeastern Africa; Arabia; Paleotethys; Neotethys

\section{Introduction}

The Phanerozoic evolution of Africa reflects both the assembly of Pangea, and the polyphased break-up of the Gondwana supercontinent (Fig. 1). Gondwana formed during the Pan-African-Brasilian orogeny from 720 to $580 \mathrm{Ma}$ (Unrug, 1996; Caby, 2003) and consisted of cratonic cores and surrounding accreted terranes. The closing of Paleotethys and complex collision of Laurussia with Gondwana in the late Paleozoic completed the growth phase of the supercontinent. The rejuvenation of late Proterozoic zones of lithospheric weakness, and particularly of major fault zones (Fig. 2), facilitated the subsequent break-up.

During Phanerozoic times, Northern and Central Africa successively corresponded to the southern margins of the Paleotethys and Neotethys oceans (Fig. 1). They periodically registered periods of rifting, sag basin development, and compressive tectonics in conjunction with changes in the rate and direction of the opening and closure of the Paleotethys, the western Neotethys, the South Atlantic Ocean, and the Indian Ocean. Sea-level fluctuations also closely affected facies development across the continental shelf, which often extended as far south as southern Niger. As a result, a nearly complete Phanerozic stratigraphic section can be observed in this large region. Moreover, several basins are - or might soon be - prolific oil and gas producers. For these reasons, their geological history has been extensively studied and these data played an important role in recent paleoenvironmental and tectonic syntheses, such as Dercourt et al. (1993), Guiraud and Bellion (1995), Guiraud and Bosworth (1997), Schandelmeier and Reynolds (1997), Dercourt et al. (2000) and Guiraud (2001); syntheses that helped us in writing our overview.

In this paper we summarize the Phanerozoic stratigraphic, paleogeographic, tectonic, and magmatic history of Northern and Central Africa (Fig. 3). This overview shall be mainly illustrated by: (1) tables showing correlations in the lithostratigraphy and tectonics over large domains, and (2) by a set of paleogeological maps, including Arabia that correspond to the eastern margin of Northern Africa up to Oligocene-Miocene times. Each of these maps concerns a more or less long time period, in order to illustrate the activity of the major faults and rift basins. This implies, for each stage, fluctuations in the sea levels that we cannot represent. We chose to draw the maximal development of the seas, which can be diachronous during one stage taking into account the large areal extent of the mapped area. For the same reasons, the age of the chosen platform-slope transition location will be specified. Finally, the reader must be aware that, due to strong uplifts occurring in some large areas such as the Hoggar Massif, the Reguibat Shield, or the western Eburnean Shield, the proposed paleogeographical limits are in some cases hypothetical and emphasized by question marks. For both text and illustrations, we refer to the time scale of Gradstein and Ogg (1996).

For some specific or complex domains, i.e. the Moroccan Hercynides, the Mauritanides Belt and foreland, the Central Atlantic Margin, the Equatorial Atlantic Margin, the Red Sea-Gulf of Aden, the East African Rifts, and the Congo Basin, detailed reviews are given in other chapters of this issue. Concerning the northwestern African Maghrebian Alpine Belt, which corresponds to the most complex domain of the area to be considered in our paper, it will be the subject of more illustration. Conversely, we shall not deal with the so far, very controversial problem of the palinspastic reconstructions of the northern African-Arabian oceanic margin through Phanerozoic times. For these topics, the reader can refer to papers by Ziegler (1989), Bard (1997), and Matte (2001) for the Paleozoic and by Ricou (1994), Stampfli et al. (2001, 2002), and Stampfli and Borel (2002) for the Mesozoic-Cenozoic. The Peri-Tethys Programme Atlas published by Dercourt et al. (2000) also provides a detailed, polyphased illustration of the paleogeographical and paleotectonic evolution of the margin between Late Carboniferous and Recent times. For these reasons we shall only represent on our paleogeological maps the hypothetical palinspastic position of some allochthonous blocks or domains.

\section{Paleozoic evolution}

\subsection{Late Pan-African fault network}

The Precambrian cratons, as well as the Pan-African Belts are cross-cut by numerous large faults. During the Pan-African stages, these faults mainly acted as sub-verti- 

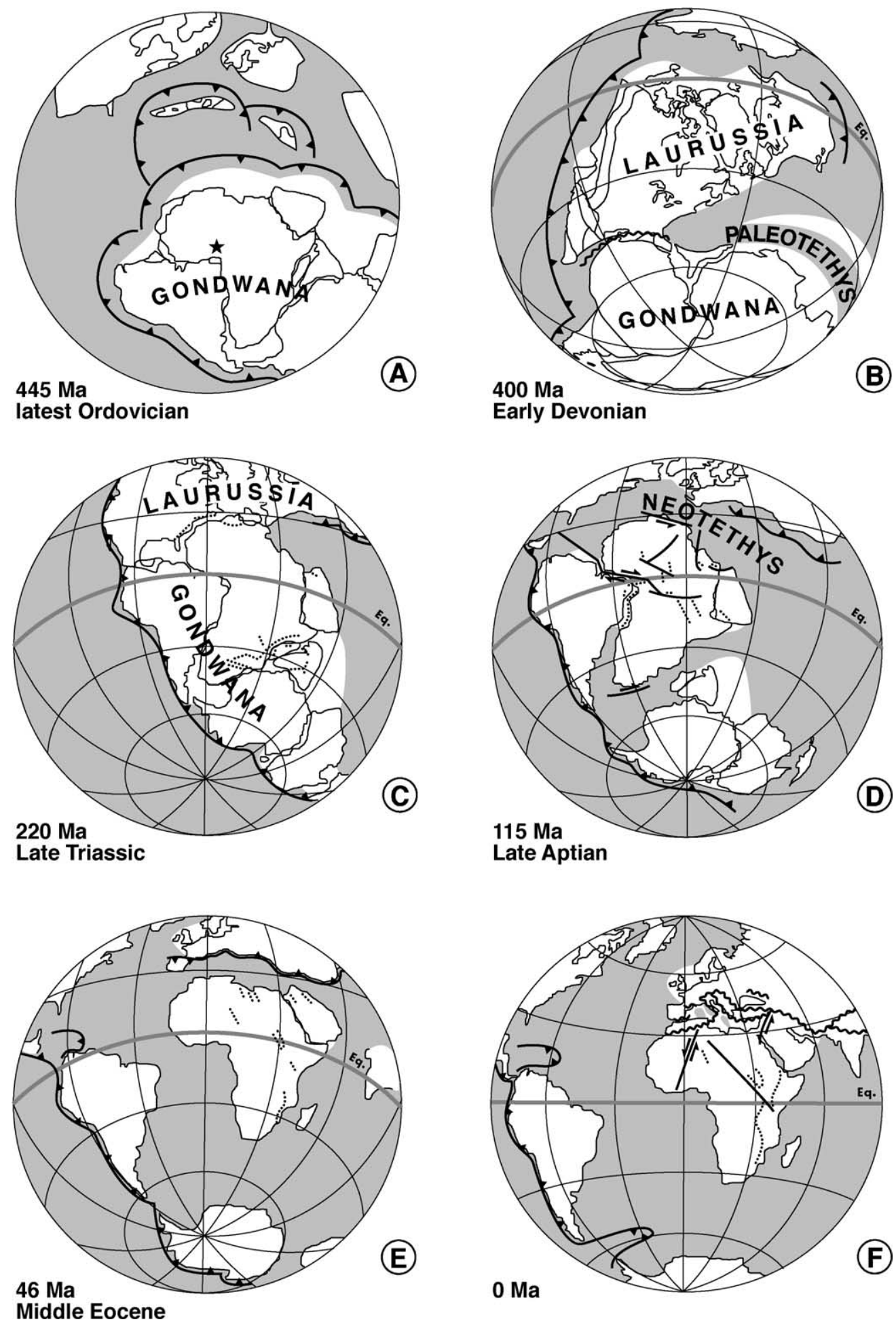

Fig. 1. Paleogeographic-paleotectonic reconstructions and Gondwana break-up, slightly modified after Guiraud and Bosworth (1999). (A) Reconstruction at $\sim 445 \mathrm{Ma}$ (latest Ordovician), black star shows the South Pole position (after Konate et al., 2003); (B) reconstruction at $4400 \mathrm{Ma}$ (Early Devonian), wavy line is the Acadian collision; (C) reconstruction at $\sim 220 \mathrm{Ma}$ (Late Triassic), dotted lines correspond to major Karoo rifts in Africa-Arabia; (D) reconstruction at $\sim 115 \mathrm{Ma}$ (Late Aptian), dotted line represent major Late Jurassic-Early Cretaceous rifts and fault zones in Africa-Arabia; (E) reconstruction at $\sim 46 \mathrm{Ma}$ (Lutetian), with major Late Senonian to Early Eocene rifts in Africa-Arabia; (F) present-day, with major Oligocene to Recent rifts and fault zones in Africa, wavy line is the Alpine fold-thrust belt.

cal strike-slip faults. The major fault zones recognized in North and Central Africa are depicted in Fig. 2. Hundreds of faults of minor importance also exist in this large domain. 


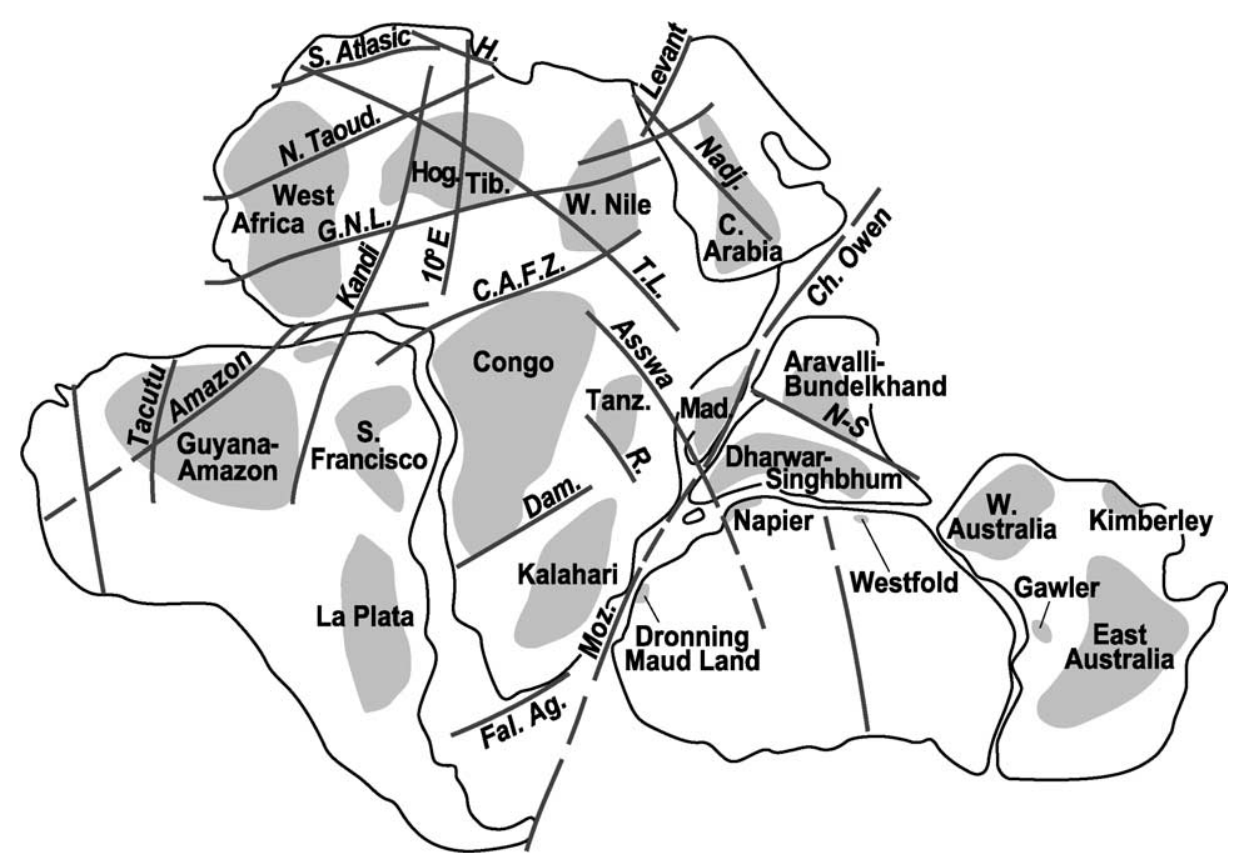

Fig. 2. Major fault zones of the Gondwana, after Guiraud et al. (2000). Apparent Archean and Paleoproterozoic cratons in grey. Ag, Agulhas; C, Central; CAFZ, Central African Fault Zone; Ch, Chain; Dam, Damara; Fal, Falkland; GNL, Guinean-Nubian lineaments; H, Hodna; Hog, Hoggar; Moz, Mozambique; N-S, Narmada-Son; N Taoud, North Taoudenni Lineament; R, Rukwa; Tanz, Tanzania; TB, Trans-Brasilano; Tib, Tibesti; TL, Tibesti Lineament. Apparent curvature of the Tibesti Lineament is due to projection.

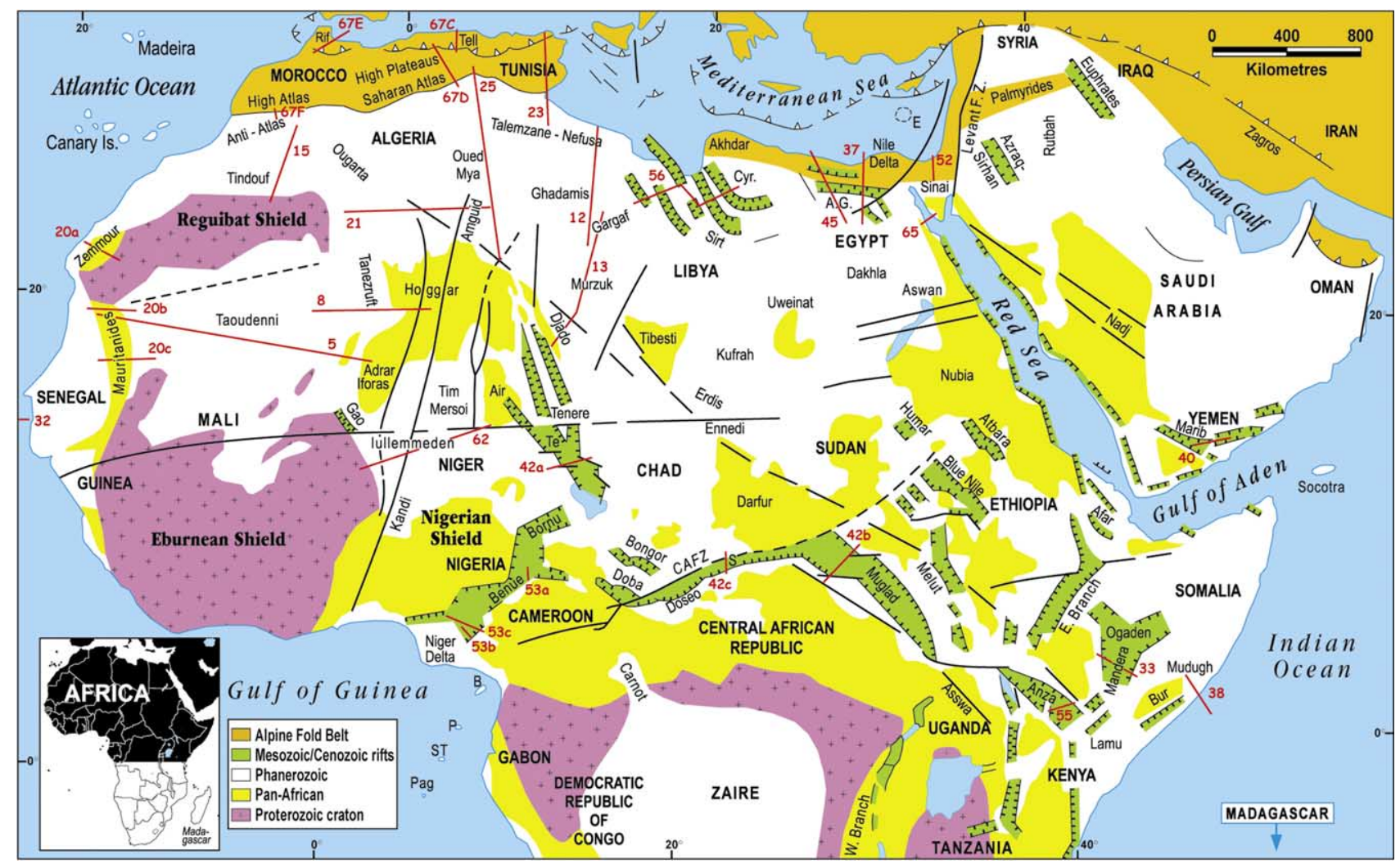

Fig. 3. Schematic geological map of Northern Africa, Central Africa and Arabia. Compiled from Wilson and Guiraud (1998). The major fault zones and Mesozoic-Cenozoic rifts are located. AG, Abu Gharadig; B, Bioko; CAFZ, Central African Fault Zone; Cyr, Cyrenaica; E, Eratosthenes Seamount; JP, Jos Plateau; P, Principe; Pag, Pagalu; S, Salamat; ST, Saõ Tomé; Te, Termit. 
The most important and more frequent breaks are $\sim \mathrm{N}-$ $\mathrm{S}$ trending, dextral strike-slip faults, e.g., the Kandi $4^{\circ} 50^{\prime}$ fault zone (Guiraud and Alidou, 1981; Caby, 1989) or the $10^{\circ} \mathrm{E}$ fault zone (Massa, 1988; Guiraud et al., 2000). Two families of conjugate faults, NW-SE sinistral and NE-SW dextral (Ball, 1980) are also known. Three major $\mathrm{N} 70^{\circ} \mathrm{E}$ to $\mathrm{N} 90^{\circ} \mathrm{E}$ trending fault zones must finally be mentioned: (1) the North Taoudenni fault zone (Guiraud et al., 2000), (2) the Guinean-Nubian Lineaments (Guiraud et al., 1985), and (3) the Central Africa fault zone (Cornacchia and Dars, 1983).

During Phanerozoic times, the frequent rejuvenation of this fault net was responsible for the regional or local tectonic evolution, with various behaviors in response to changes in the stress fields (Guiraud and Bellion, 1995; Guiraud and Bosworth, 1999; Coward and Ries, 2003). This phenomenon also influenced the development of magmatic provinces (Wilson and Guiraud, 1998).

\subsection{Early Cambrian basins and tectonics}

Dating of the latest Proterozoic-earliest Cambrian series along Northern and Western Africa remained very controversial, until new paleontological and radiogenic ages were obtained during the last 10 years. The following geological history can now be proposed.

Over the West African Craton, the Early Cambrian corresponds to thin series unconformably overlying Proterozoic sediments or metamorphics (Figs. 4 and 5). These series consist of glacial deposits capped by marine carbonate layers and then terrigenous units, often including ash beds (Bertrand-Sarfati et al., 1995). The formations thicken northwards and eastwards coincident with the gradual disappearance of the glacial facies. Over the large Pan-African eroded belt, molassic series were deposited, mainly preserved in rift basins (Fig. 6). These basins are well documented in the western Hoggar Massif, where their

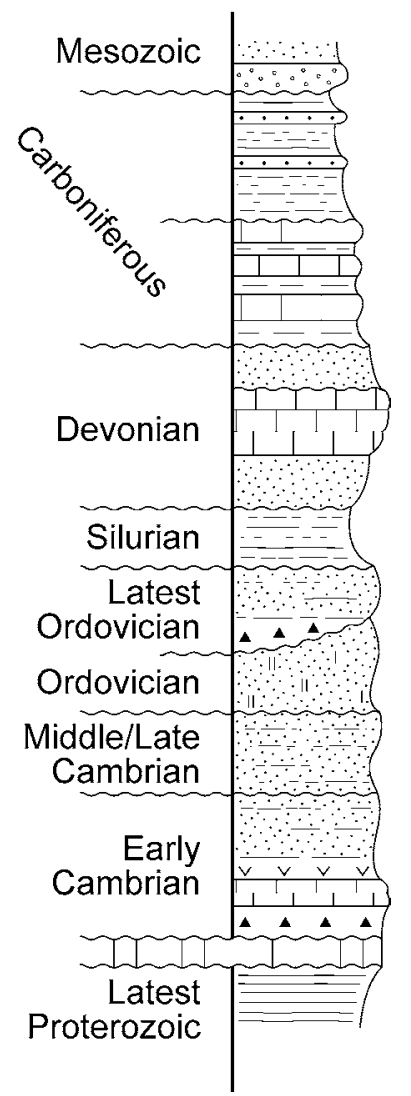

Fig. 4. Synthetic lithostratigraphic column of the Paleozoic of the Taoudenni Basin, modified from Bertrand-Sarfati et al. (1995) and Villeneuve (this issue). Black triangles, tillites; $\vee$, ash beds.

development is clearly associated with the rejuvenation of $\mathrm{N}-\mathrm{S}$ tending faults. The molassic series here correspond to the "Série Pourprée de 1'Ahnet" that can be up to $6 \mathrm{~km}$ thick, including arkosic to greywacke formations interbedded with stromatolitic limestones and volcanics (reviewed in Caby, 2003). These series also contain some

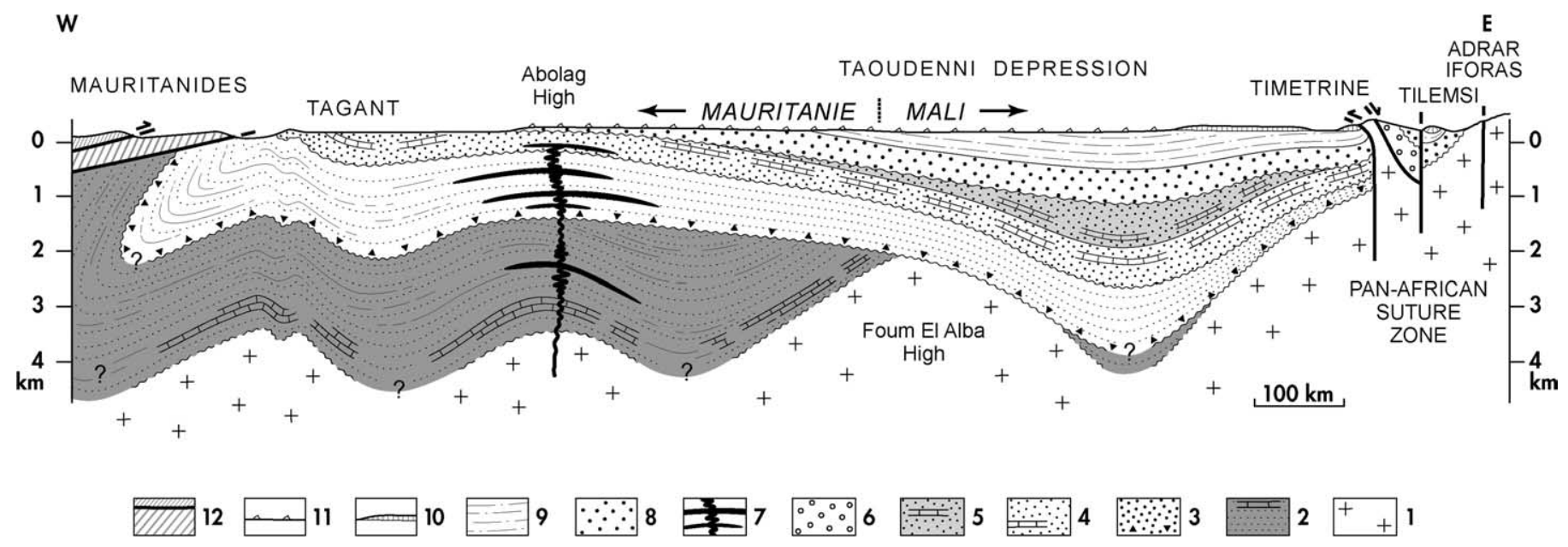

Fig. 5. Schematic geological cross-section of the Taoudenni Basin. (1) Pan-African basement; (2) Late Proterozoic; (3) Cambrian-Ordovician; (4) Silurian-Devonian; (5) Carboniferous; (6) Permian-Triassic; (7) Early Liassic dolerites; (8) Middle Jurassic-Albian; (9) Late Cretaceous; (10) Paleocene; (11) Recent sand dunes; (12) Allochthonous units. 


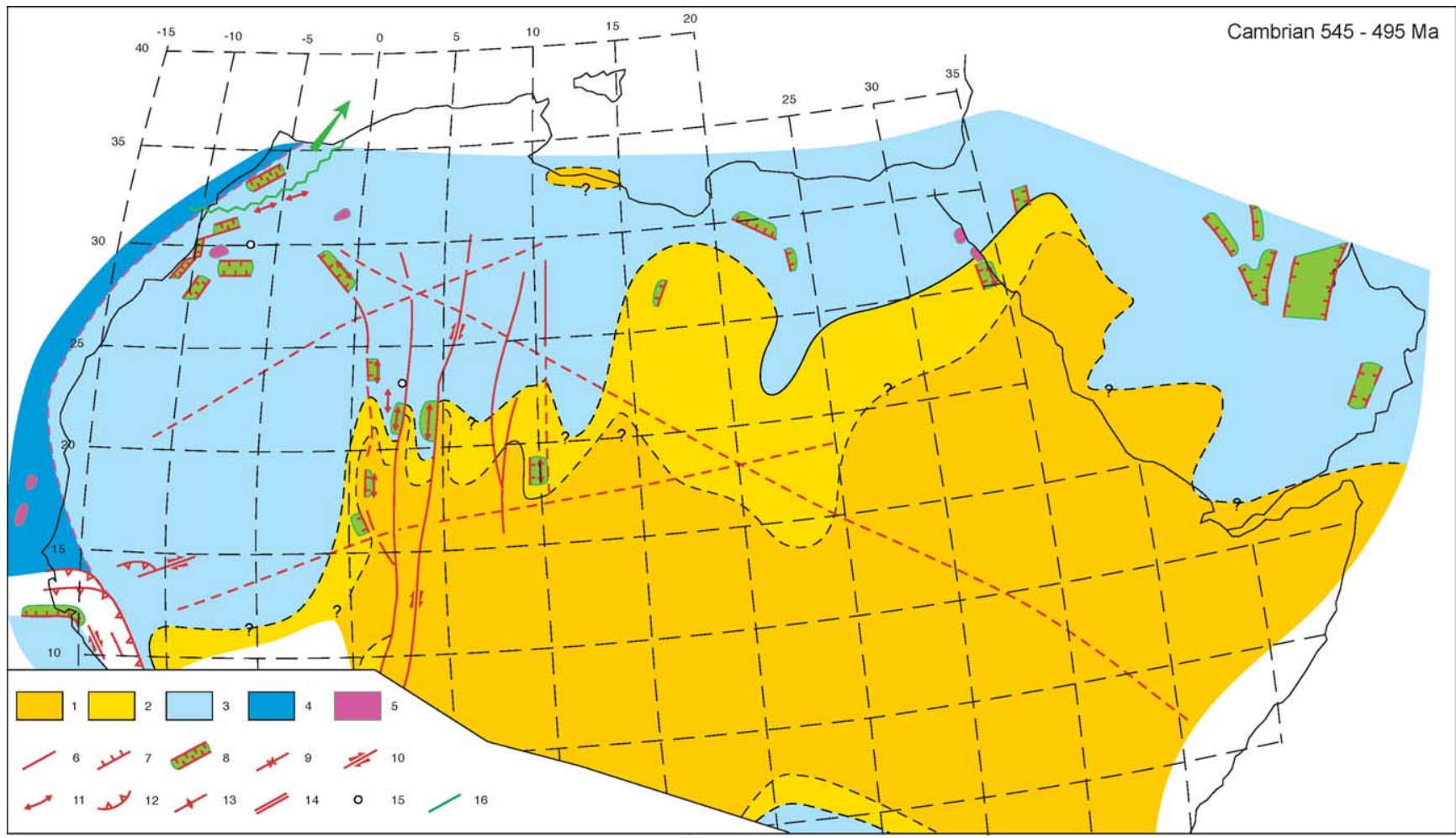

Fig. 6. Cambrian (545-495 Ma) paleogeological map. (1) Continental, exposed land; (2) continental basin; (3) platform; (4) slope and deep marine; (5) effusive magmatism; (6) fault; (7) normal fault; (8) active rift or subsident basin; (9) depocenter axis; (10) strike-slip fault; (11) anticline axis; (12) thrust; (13) active high; (14) oceanic ridge; (15) annular alkaline complex; (16) dyke.

glauconites and associated stromatolites, which suggest that some marine incursions occurred (Caby, pers. comm.). The molasse is intruded by the syn-sedimentary Taourirt granites dated between 539 and $523 \mathrm{Ma}$ (Paquette et al., 1998).

Similar and synchronous thick molassic basins are known in the Moroccan High Atlas and Anti-Atlas (reviewed in Piqué, 2001), in the Dor el Goussa Basin of central Libya (Mourizidié Fm.; Bellini and Massa, 1980), in Northern Niger (Proche Ténéré Fm.; Greigert and Pougnet, 1967), in Cyrenaica (Wennekers et al., 1996) (Fig. 7), in al Kufrah Basin (Lüning et al., 2000), in southeastern Egypt (Hammamat Group; Geological Survey of Egypt, 1981), and in the Jafr Basin of southern Jordan (Keegan et al., 1990). Rift salt basins developed along eastern Arabia (Alsharan and Nairn, 1997; Galeazzi et al., 2001).

The Hoggar Province rift basins underwent strong compressional deformations by the latest Early Cambrian, around 518-520 Ma (reviewed in Caby, 2003). This tectonic event, defined and named the "Iskelian" event by Gravelle (1969), generated folding (Fig. 8) and planar cleavage that imply $\sim \mathrm{E}-\mathrm{W}$ to ENE-WSW shortening (Caby, 2003). The intensity of deformations was at its maximum near the Pan-African Belt-West African Craton suture, which was then rejuvenated. It decreases northwards and eastwards, yet folding and faulting also affect the Proche Ténéré and Hammamat Formations of Niger and Egypt. By the same time period ( 520 Ma) basin
$\mathrm{N}$
Jebel Al Akhdar
Cyrenaica

Southeastern Sirt troughs

\section{Al Kufrah} Basin
S

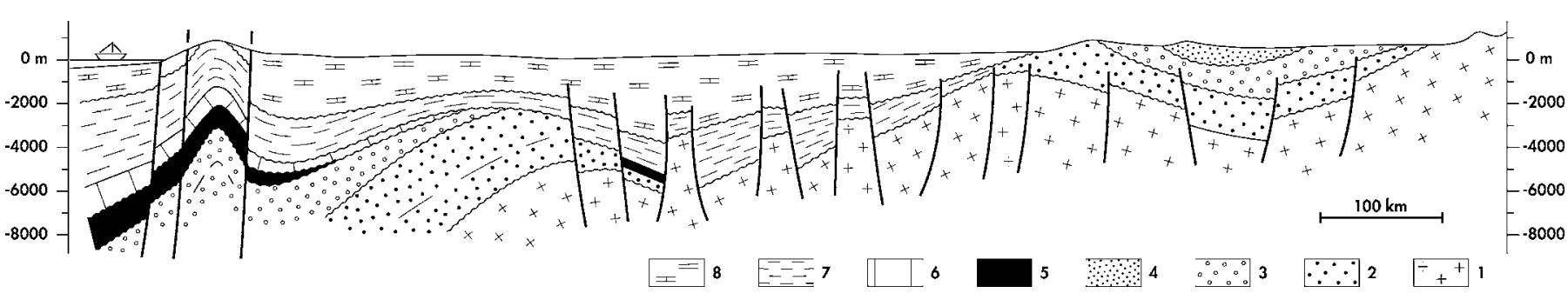

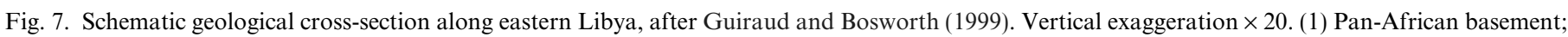

(2) Early Paleozoic; (3) Late Paleozoic; (4) undifferentiated Mesozoic; (5) Triassic; (6) Jurassic; (7) Cretaceous; (8) Cenozoic. 


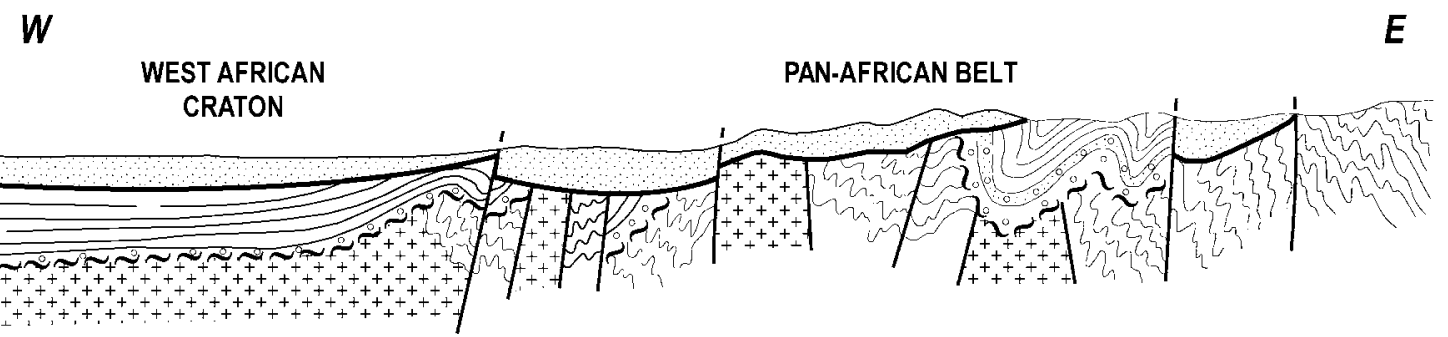

Fig. 8. Schematic geological cross-section along western Hoggar, modified from Beuf et al. (1971). The thick undulated line underlines the base of Early Cambrian series. The thick continued line corresponds to the base of Middle Cambrian.

inversion and thrusting occurred along the southwestern margin of the West African Craton (Villeneuve and Cornée, 1994), giving birth to the Rokelide Belt.

From a geodynamic point of view, the Early Cambrian rifting and magmatism denote late orogenic crustal thinning and tectonic escape (Burke et al., 2003), while the following compressional event appears as the latest Pan-African event. A relative tectonic quiescence prevailed during most of the following Paleozoic time.

\subsection{Mid-Cambrian to Late Silurian (platform) evolution}

\subsubsection{Mid- to Late Cambrian}

The large platform that initiated in the Early Cambrian, locally deformed before the Middle Cambrian, would develop over northern and western Africa, extending from the present-day Atlantic margin to Arabia. General trends in the paleoenvironments can be recognized from Central Africa towards the western, northern, and northeastern margins (Fig. 6): continental deposits change to marginal marine and then offshore sediments (Guiraud et al., 2001; Carr, 2002). Over such a large region, during Cambrian times the initiation of sedimentation as well as marine transgression was diachronous. Fluvial or estuarine sandstones were deposited over wide basins, e.g., the Hassaouna Formation of Libya (Figs. 9 and 10), grading into shales toward Morocco. Thicknesses are generally approximately several hundreds of meters, except along some N-S to NE-SW trending highs that will persist through the Paleozoic history, e.g., Amguid-El Biod in Algeria or Uweinat-Bahariya in Egypt, or some subsident basins. A few troughs were active, particularly the Moroccan Meseta

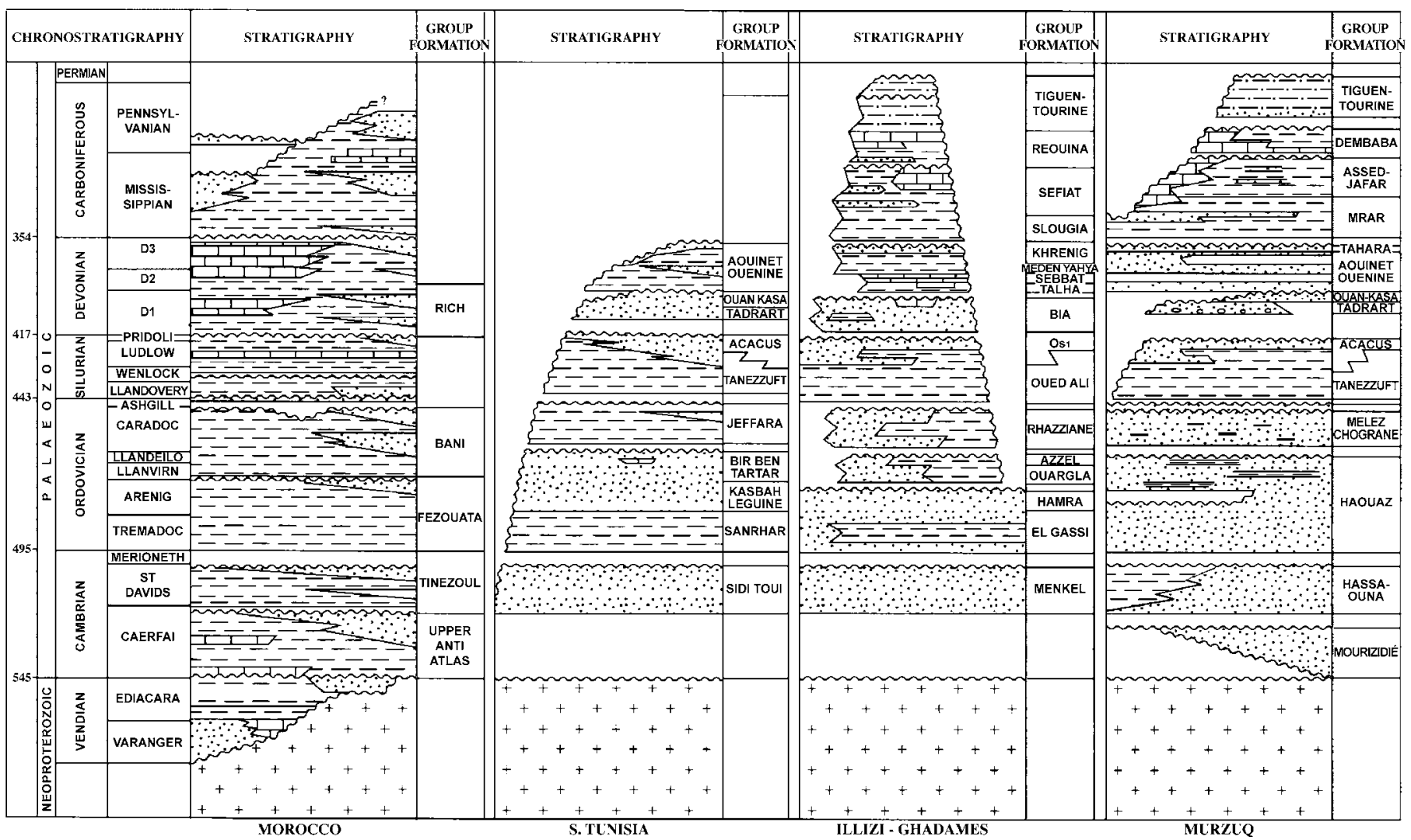

Fig. 9. Simplified Early Paleozoic lithostratigraphy for selected northwestern African locations, modified after Crossley and McDougall (1998). 


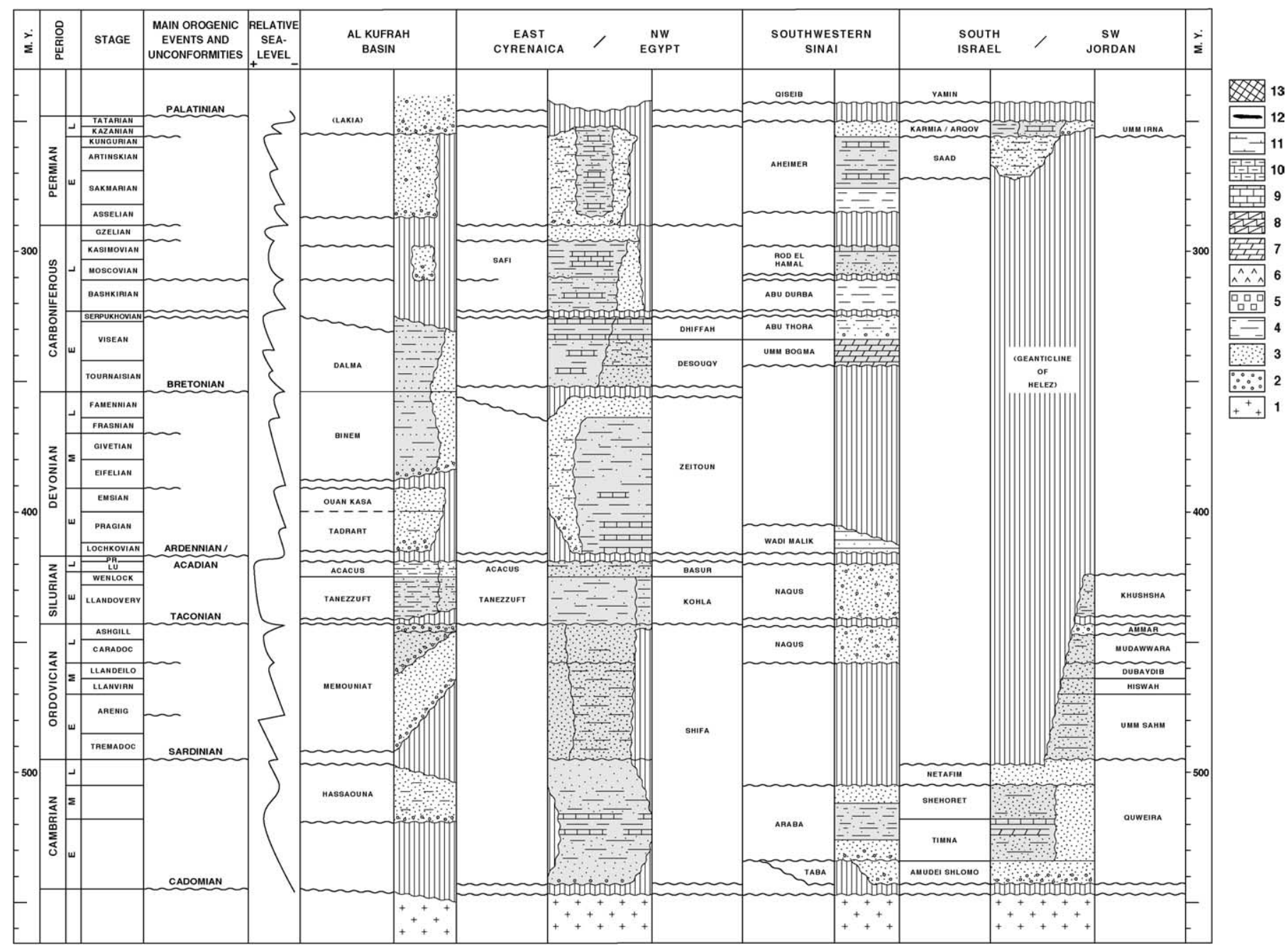

Fig. 10. Lithostratigraphic and tectonic correlation chart of Paleozoic sediments of some northeastern African and northwestern Arabian basins, slightly modified from Guiraud and Bosworth (1999). The names mentioned for the main events were defined in the Variscan Orogen or in the northern Appalachians. Sea level curve is simplified from Schandelmeier and Reynolds (1997). Grey shading indicates marine formations. Hatching indicates stratigraphic hiatuses (non-deposition or erosion). Lithologies: (1) metamorphic and magmatic basement; (2) conglomerates; (3) sandstones; (4) shales, clays; (5) halite; (6) gypsum; (7) dolomites; (8) dolomite limestones; (9) limestones; (10) clayey limestones; (11) chalk; (12) flints, cherts; (13) laterites.

Basin - presumably located far away northwestwards by these times - that registered the deposition of more than $4 \mathrm{~km}$ of Middle Cambrian shale, sandstone, and volcanics (Destombes et al., 1985) probably in slope environments.

By the end of the Cambrian, a brief drop in sea level was registered along the north African margin, which probably reflects, in part, regional uplift caused by gentle tectonic deformation (Fabre, 1988). The Cambrian-Ordovician transition ("Sardinian") tectonic event was responsible for systematic hiatuses or slight unconformities in the sedimentary sequences along the northern African platform (Figs. 9 and 10) as well as in the Tindouf Basin (Boote et al., 1998) or in the Taoudenni Basin (Fig. 4) and the Mauritanides fold-thrust belt (Léchorché et al., 1991). Southwards, a synchronous unconformity is mentioned in the Zaire Basin of Central Africa (Daly et al., 1992). Northwards, strongest deformation occurred in the southern Paleotethys domain, which suggests that this event corresponds to a minor, plate-scale event.

\subsubsection{Ordovician}

During the Ordovician, exposed lands prevailed in northern Egypt and Sudan (Fig. 11A) that registered intrusion of numerous magmatic bodies and resulted in the uplift of large areas, e.g., Uweinat or Nubia (Guiraud and Bosworth, 1999). Westwards, fluvial to shallow marine sandstones were deposited, passing to shales towards Morocco (Figs. 9 and 10). The deposits show marine transgressions, initiating from early Tremadoc, interposed with minor regressions up to the early Ashgill (Carr, 2002). The thickness of the series can reach $1200 \mathrm{~m}$ in al Kufrah Basin, along the northern Cyrenaica-Sirt margin, and in the northern Ghadamis Basin (Wennekers et al., 1996), while they are reduced along some $\mathrm{N}-\mathrm{S}$ trending highs. A very frequent break in the series, highlighted by gentle angular unconformities of the underlying formation, denotes a minor pre-Caradoc (Medial Ordovician) tectonic event (Fabre, 1976, 1988; Guiraud and Bosworth, 1999). This event, so far poorly studied, was responsible for 


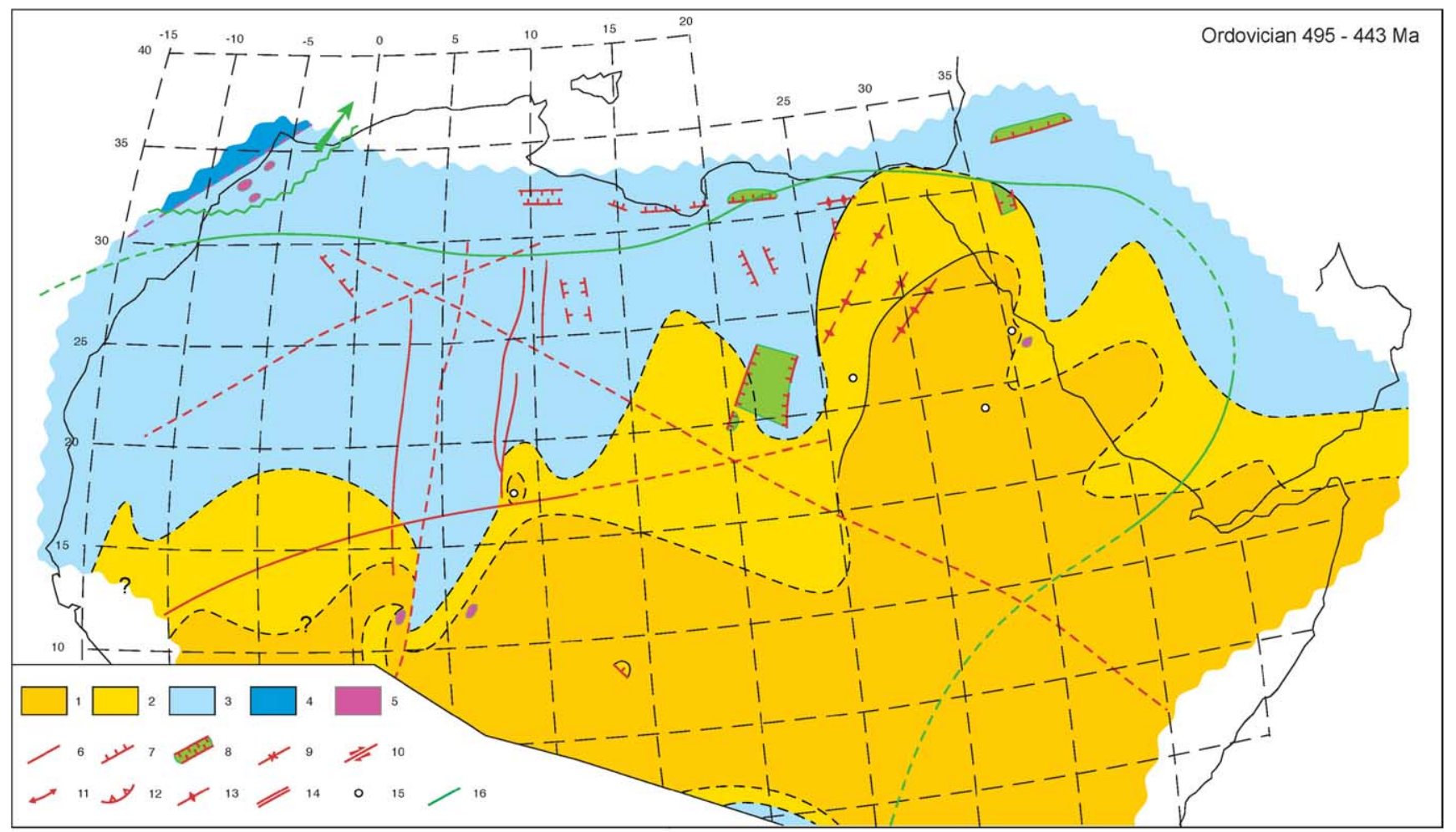

A

Fig. 11A. Ordovician (495-443 Ma) paleogeological map. Same legend as Fig. 6. The green line shows the maximum extent of the latest Ordovician ice sheet.

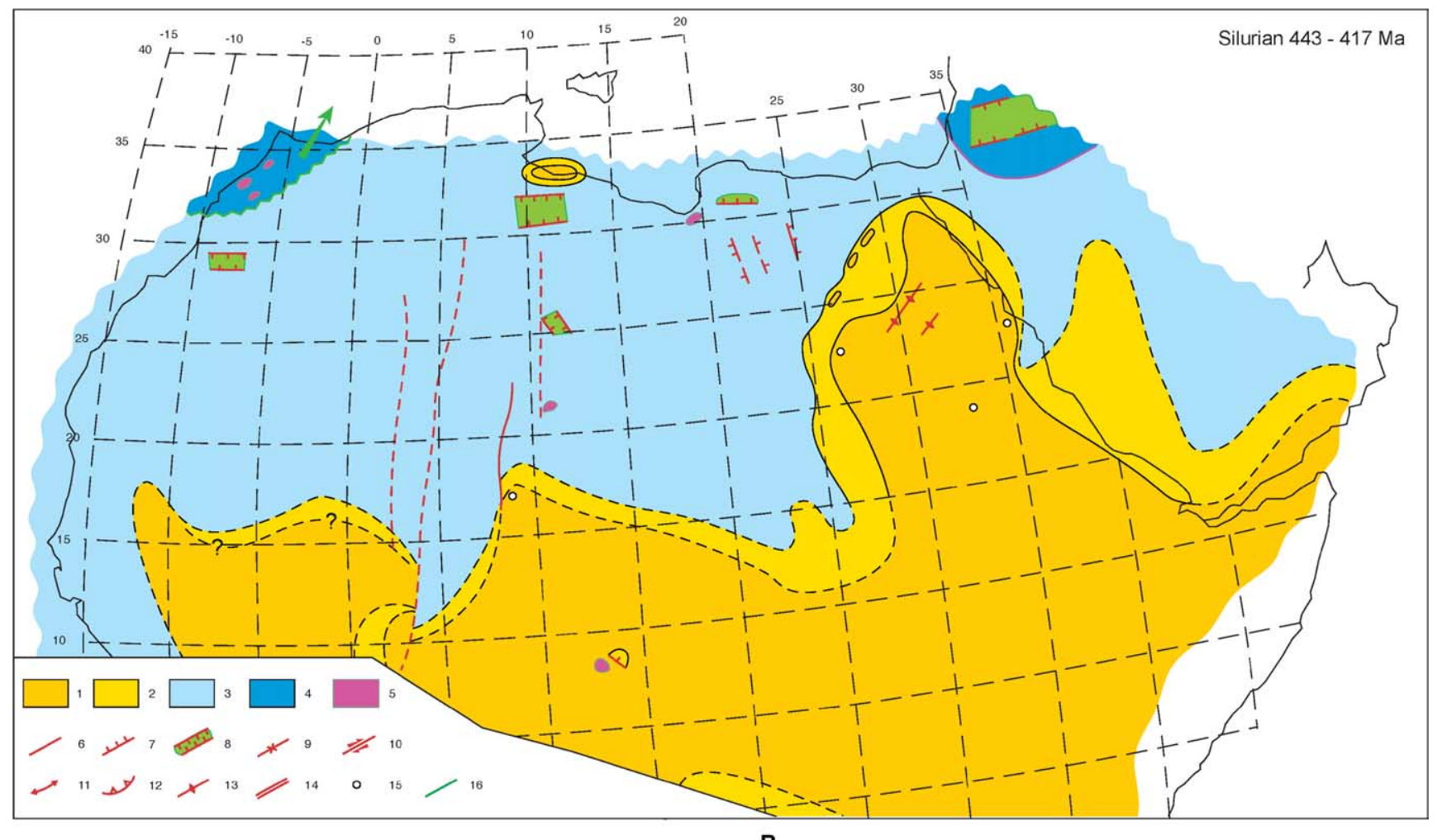

Fig. 11B. Silurian (443-417 Ma) paleogeological map. Same legend as Fig. 6. 


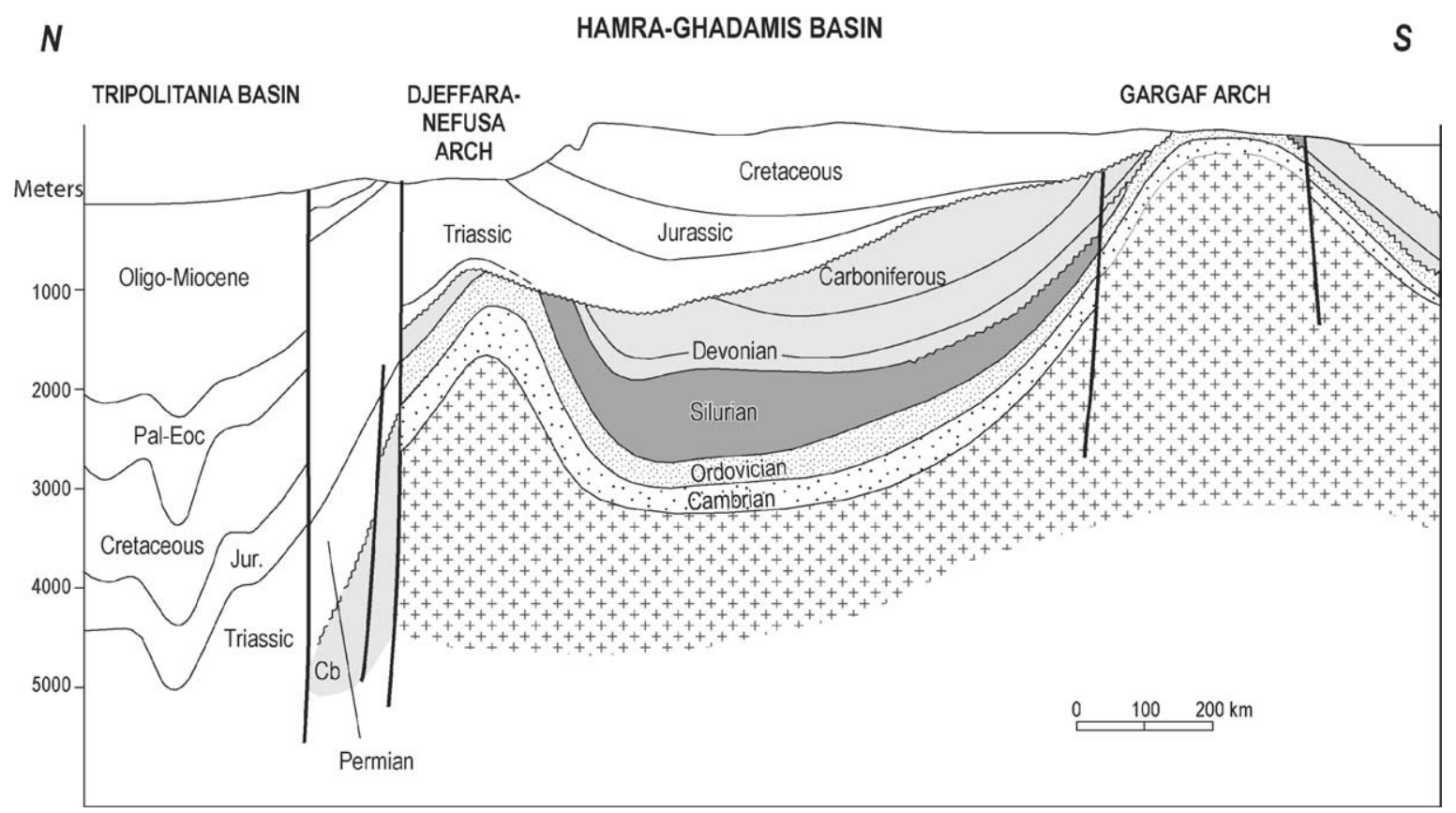

Fig. 12. Schematic geological cross-section across the Hamra-Ghadamis Basin of northwestern Libya, slightly modified after Boote et al. (1998).

transpressional deformation including drag folds along $\mathrm{N}-$ $\mathrm{S}$ trending faults around the Hoggar Massif (Beuf et al., 1971; Boudjema, 1987).

The latest Ordovician, late Ashgill times registered a strong global glaciation (Hirnantian glaciation) responsible for a global low stand of sea level. Northwestern Africa was located in the paleo South Pole area (Fig. 1A) and glacial deposits are frequent, both in continental and marine domains. In the studied area, very frequent sub-glacial fluvial channels have been identified, flooding northwards or northwestwards (e.g., Beuf et al., 1971; Ghienne and Deynoux, 1998). Shorelines advanced towards the north (Fig. 11A). However, shallow marine and offshore marine sediments of glaciogenic origin (mainly mudstone or micro-conglomeratic shale) were deposited along the north Saharan platform (Carr, 2002).

This brief climatic event was immediately followed by gentle but widely registered tectonism, the "Taconian" event that underlines the Ordovician-Silurian transition. Unconformable Silurian formations frequently overlay uplifted or tilted blocks and remnant glacially sculpted hills (Stump et al., 1995; Crossley and McDougall, 1998; Guiraud and Bosworth, 1999; Klitzsch, 2000).

\subsubsection{Silurian}

The Early Silurian was first characterized by deglaciation, entailing a major transgression on the northern African platform (Fig. 11B). Shallow marine domains developed westwards and eastwards of a large $\sim \mathrm{N}-\mathrm{S}$ high trending from Sudan to southern Egypt (Schandelmeier and Reynolds, 1997; Guiraud et al., 2001). Dominantly organic-rich graptolite shale was deposited, e.g., the
Tanezzuft Formation in the Murzuq-al Kufrah Basin (Figs. 9 and 10), while a sandstone belt fringed the shorelines and reduced fluvial basins remained in the continental domain. Subsidence rates decreased compared to those in the Ordovician. Exceptions occurred along the Tinduf Basin-Anti-Atlas confines in southern Morocco (Destombes et al., 1985), along the Hamra-Ghadamis Basin (Wennekers et al., 1996) (Fig. 12), the southwestern Murzuq Basin (Wennekers et al., 1996), and along the northeastern Libyan Cyrenaican margin, which underwent high rates of sedimentation during most of Paleozoic times (Wennekers et al., 1996).

During the Late Silurian, sandstone deposition dominated, e.g., the shallow-marine Acacus Sandstone of the Murzuq-al Kufrah Basin. Sedimentation was generally interrupted by the Silurian-Devonian transition, as a result of tectonic instability and a drop in global sea level.

\subsection{Caledonian (Early Acadian/Ardennian) event}

Breaks in the series (Figs. 9 and 10) and frequent angular unconformities below Early Devonian formations (Fig. 13) are evidence of a tectonic event. A synthetic study of deformations that then occurred in northern and western Africa still remains to be done. However, some authors briefly quote slight tectonic deformations, mainly mentioned as uplifting of some trends or blocktilting (e.g., Klitzsch, 1963; Guardia, 1975; Deynoux et al., 1985; Wennekers et al., 1996; Semtner et al., 1997; Boote et al., 1998; Crossley and McDougall, 1998; Guiraud and Bosworth, 1999; Piqué, 2001; Coward and Ries, 2003). 


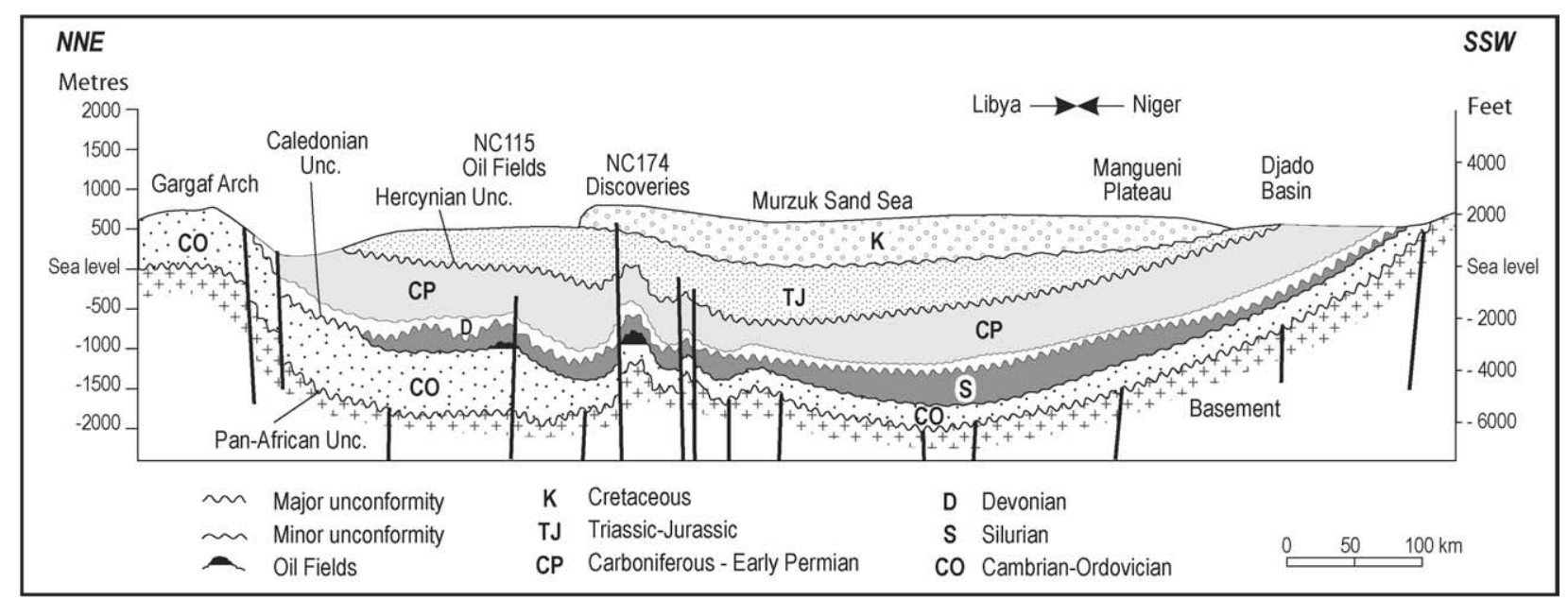

Fig. 13. Schematic geological cross-section through the Murzuq Basin, modified from Davidson et al. (2000).

Taking into account the plate tectonic framework, especially the Acadian collision that then occurred between Gondwana and Laurussia (Torsvik, 1988) (Fig. 1B), the published data and some unpublished studies (R.G.), we can propose the following schematic behavior of the major structures (Fig. 14A):

- uplift of NW-SE to NNW-SSE trending highs; e.g., Kalanshiyu (eastern Libya) and Brak-Ben Ghanimah (eastern Murzuq Basin margin) and Ougarta;

- sinistral strike-slip along $\sim \mathrm{N}-\mathrm{S}$ trending major fault zones cross-cutting the Hoggar Massif;

- folding of ENE-WSW to NE-SW highs, e.g., Gargaf (Figs. 12 and 13) and arches of Egypt;

- thrusting along the Rifian domain.

These structural features imply $\sim \mathrm{NW}-\mathrm{SE}$ shortening, probably of moderate intensity, though much weaker than the Hercynian one (as described hereafter in Section 2.6).

\subsection{Devonian}

The late Caledonian uplifts were accompanied by a regional marine regression, underlined by the progradation during the early Devonian of braid plains over the south Algeria-Libya basins and deposition of continental sandstone formations, e.g., the Tadrart Formation in al Kufrah and Murzuq basins (Figs. 9, 10, 14A). Northwards, tidal flat deposits and shallow-marine sandstones extensively developed over North Africa, evolving to shallow-marine mudstones in Morocco (Carr, 2002). Northeastern Africa exhibited large exposed lands in Sudan and southern Egypt, and some local highs, e.g., Kalanshiyu (Guiraud and Bosworth, 1999). Along this domain of the Paleotethys margin, the transition between continental and slope environments was probably abrupt during most of the Paleozoic.
The late Early Devonian registered a brief marine transgression during the Emsian, with the occurrence of shallow marine sandstones to offshore marine mudstones all along the North African platform (Carr, 2002) and some carbonates in Morocco and northwestern Egypt.

The transition between the Early Devonian and the Middle Devonian was marked by a significant regional tectonic event - the Mid-Acadian (main) event - that often results in the reactivation of the structures linked to the former Caledonian event. This Acadian event entailed erosion that increased that associated with the Caledonian and often resulted in significant thinning of the Early Devonian formations.

The Middle and Late Devonian were initiated by deposition of transgressive deposits, the latter generally corresponding along the Algerian-Libyan basins to the organic-rich shales of the "Argile Radioactive" Formation. During this period, the general SSE to NNW continental to marine trend was permanent (Fig. 14B), only disturbed by mild uplift of some highs such as the Ougarta, the Gargaf Arch (Carr, 2002), the Tihemboka Arch and the Tiririne High of western Libya (Echikh and Sola, 2000). The sediments evolved from fluvial conglomerates and sandstones to tidal and then shallow marine shales and limestones (Figs. 9 and 10). The large development over the Algerian and Moroccan platform of limestone facies, including local reef facies, suggests warming of the climate. Thick terrigenous series were deposited along the Cyrenaican margin and the Ghadamis Basin (Wennekers et al., 1996), and similarly along the southern edge of the Anti-Atlas (Soulaimani et al., 1997) (Fig. 15) and north-central Morocco (Coward and Ries, 2003).

\subsection{Carboniferous-Permian and Hercynian events}

Frequent breaks in the series (Figs. 9 and 10) and local angular unconformities below Early Carboniferous formations bear witness of a tectonic event that was registered 


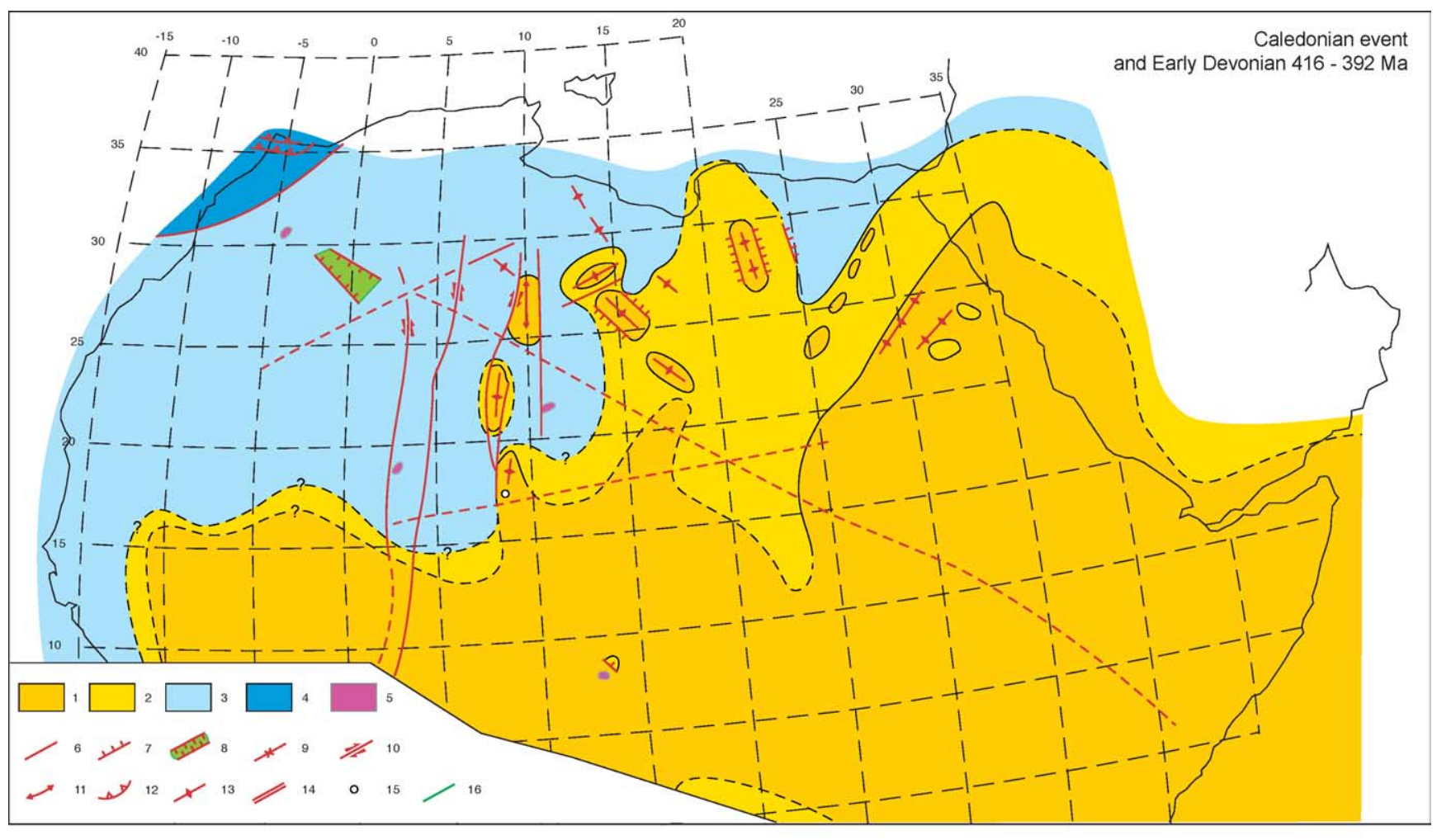

A

Fig. 14A. Caledonian event and Early Devonian (416-392 Ma) paleogeological map. Same legend as Fig. 6.

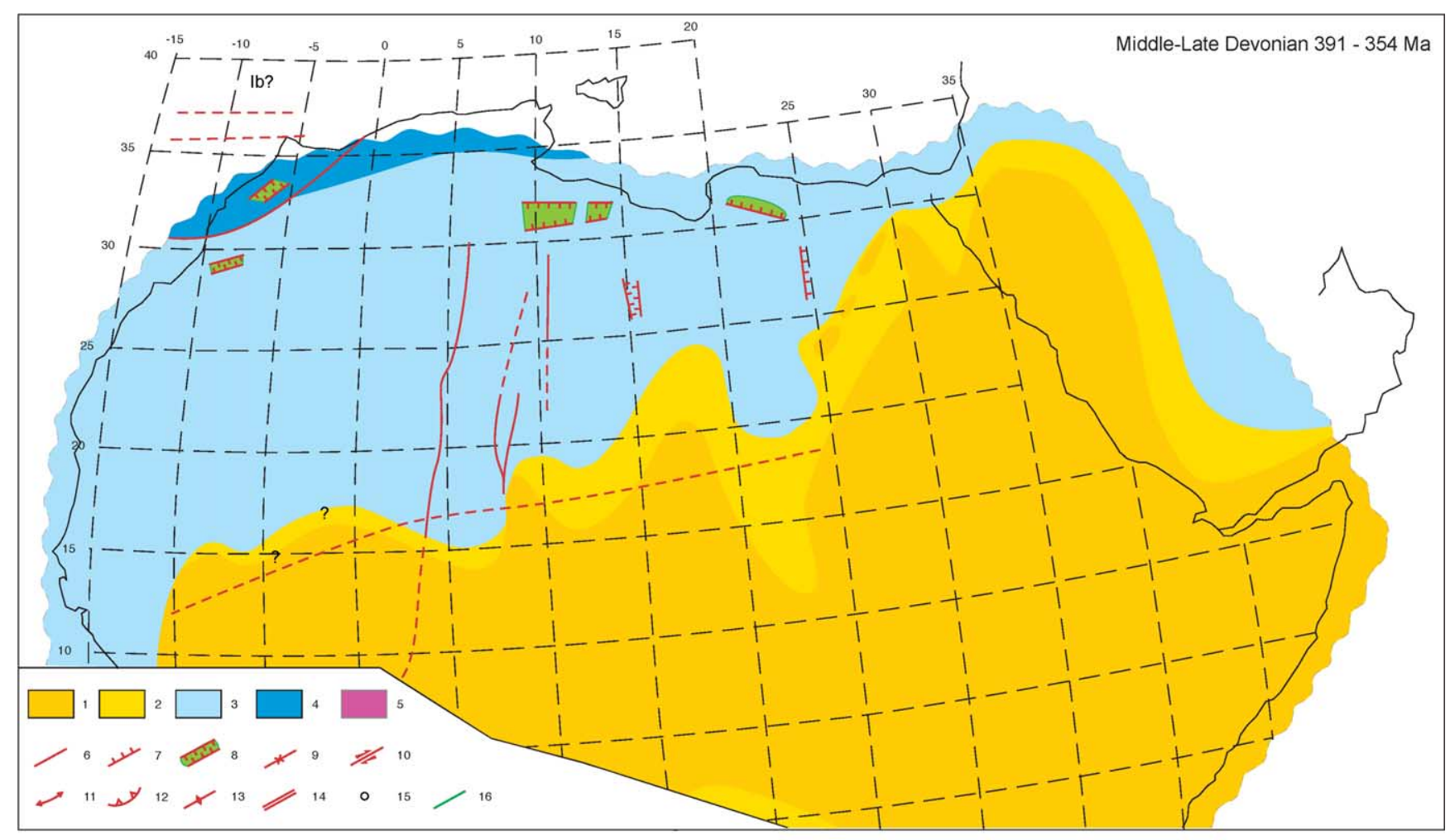

B

Fig. 14B. Middle-Late Devonian (391-354 Ma) paleogeological map. Same legend as Fig. 6. Ib, Iberia. 


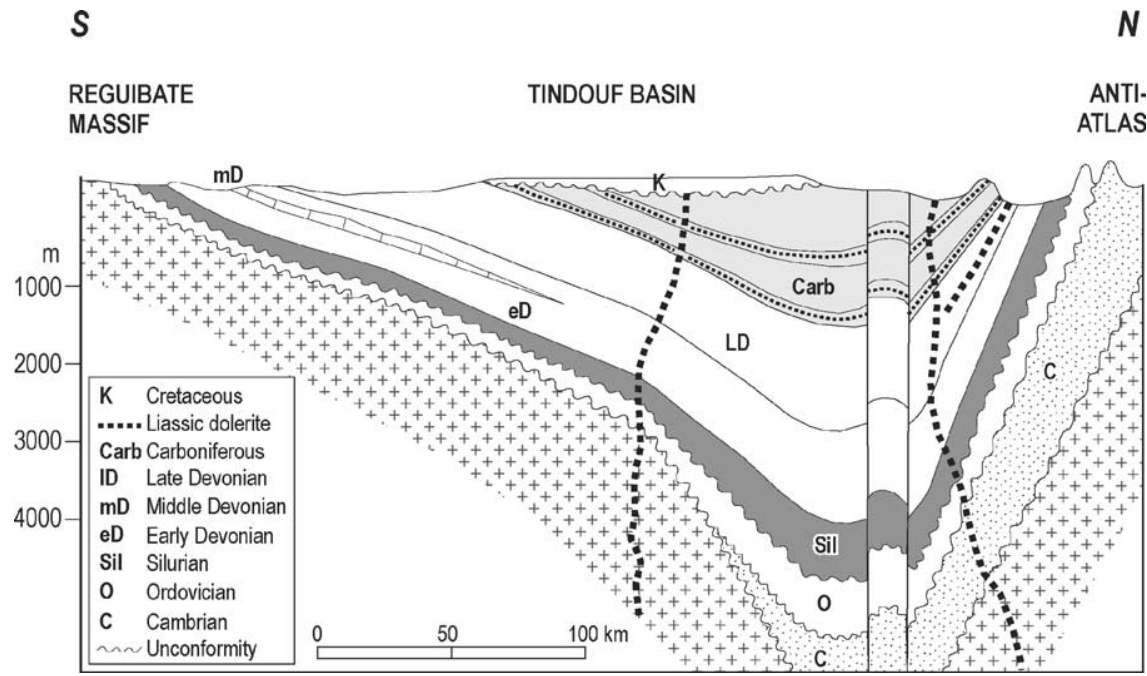

Fig. 15. Schematic geological cross-section through the Tindouf Basin, slightly modified from Boote et al. (1998) and Piqué (2001).

around the Devonian-Carboniferous transition along the northern and western African platform, as well as in the Arabian plate (Guiraud and Bosworth, 1999). The deformations correspond to block tilting, domal uplift, and local folding associated with the movement of major $\mathrm{N}-\mathrm{S}$ trending strike-slip faults. Northwards some massifs located in the present-day Alpine Belt of Morocco and Algeria, in the Middle Atlas, Rif, and Kabylia (reviewed in Piqué, 2001 and Hoepffner et al., this issue), then experienced strong folding and metamorphism. This is why this event can be considered as the local manifestation of the "Bretonian" or "Late Acadian" tectonic event corresponding to the first stage of the Hercynian Orogeny. Yet, a general study of this event so far remains to be realized in the intra-continental domain.

Along the North African platform, this event resulted in minor paleogeographic changes, principally in the proximity of some uplifted arches (Fig. 16A). The sea level rose during the Early Carboniferous. However, a general SENW trend remained over Libya, with transition from continental sandstone to marginal-marine shaly sandstone and then offshore-marine mudstone (Carr, 2002). A mixed siliciclastic-carbonate platform tended to develop during the Visean along the northernmost margin as in some areas the Algerian-Tunisian platform and Morocco (Figs. 9 and 10). A brief cooling in the climate occurred around the Tournaisian-Visean transition, as underlined by the deposition of tillites in the Tim Mersoi Basin, westwards of the Air Massif (Moussa, 1992). The occurrence of strong subsidence in some basins must be stressed, e.g., in the N-S trending Tehenu Basin along the Libyan-Egyptian confines (Keeley, 1994; Wennekers et al., 1996), along the NW-SE trending Saoura Basin of western Algeria (Conrad, 1984), along the southern Anti-Atlas (Soulaimani et al., 1997), and in north-central Morocco (Coward and Ries, 2003).

Tectonic instability rejuvenated during the late Early Carboniferous ( late Visean-earliest Serpukhovian), resulting in basinal or local unconformities in the Alge-
rian-Saharan basins (Boudjema, 1987; Fabre, 1988) as in Libya and Egypt (Guiraud and Bosworth, 1999; Echikh and Sola, 2000). Al Kufrah Basin was widely uplifted and became exposed land. Weak dextral transpressional deformation occurred along the $\mathrm{N}-\mathrm{S}$ trending fault zones of southern Algeria, in response to NE-SW shortening (Boudjema, 1987). Stronger shortening, associated with metamorphism, was registered in some massifs now localized in Central Morocco (Piqué, 2001) that leads us to consider these effects as local echoes of the "Sudetic" event defined in Europe.

This event entailed a regression, probably increased by a brief cooling in the climate that occurred during the early Bashkirian as evidenced by the development of continental glacial deposits in northern Zaire, Eritrea, and southern Arabia (Schandelmeier and Reynolds, 1997). A transgression followed along the northern African platform that peaked in the Moscovian with the development of a large evaporitic and then carbonate platform. This platform extended southwards up to the Tim Mersoi Basin of northern Niger and the northern Taoudenni Basin (Fig. 16B), and provides evidence of warm climates. During this period, some tectonic instability was registered in the Murzuq Basin, in Egypt, and along the northwestern Arabian platform, with numerous active local arches and basins, amongst which was the still subsident Tehenu Basin. This instability increased during the Late Carboniferous, resulting in a general uplifting of the Saharan platform and terrigenous continental sedimentation in the remaining basins, e.g., the Tiguentourine Formation in the Illizi and Murzuq basins (Figs. 9, 17A and 17B). Along the southern Saharan platform, the continental environments carried on up to the Late Cenomanian as evidenced by the deposition of the famous so called "Continental intercalaire" series (Kilian, 1931; Lefranc and Guiraud, 1990) (Fig. 18).

The tectonic deformations peaked by the latest Carboniferous-earliest Permian times, registering in Northern and 


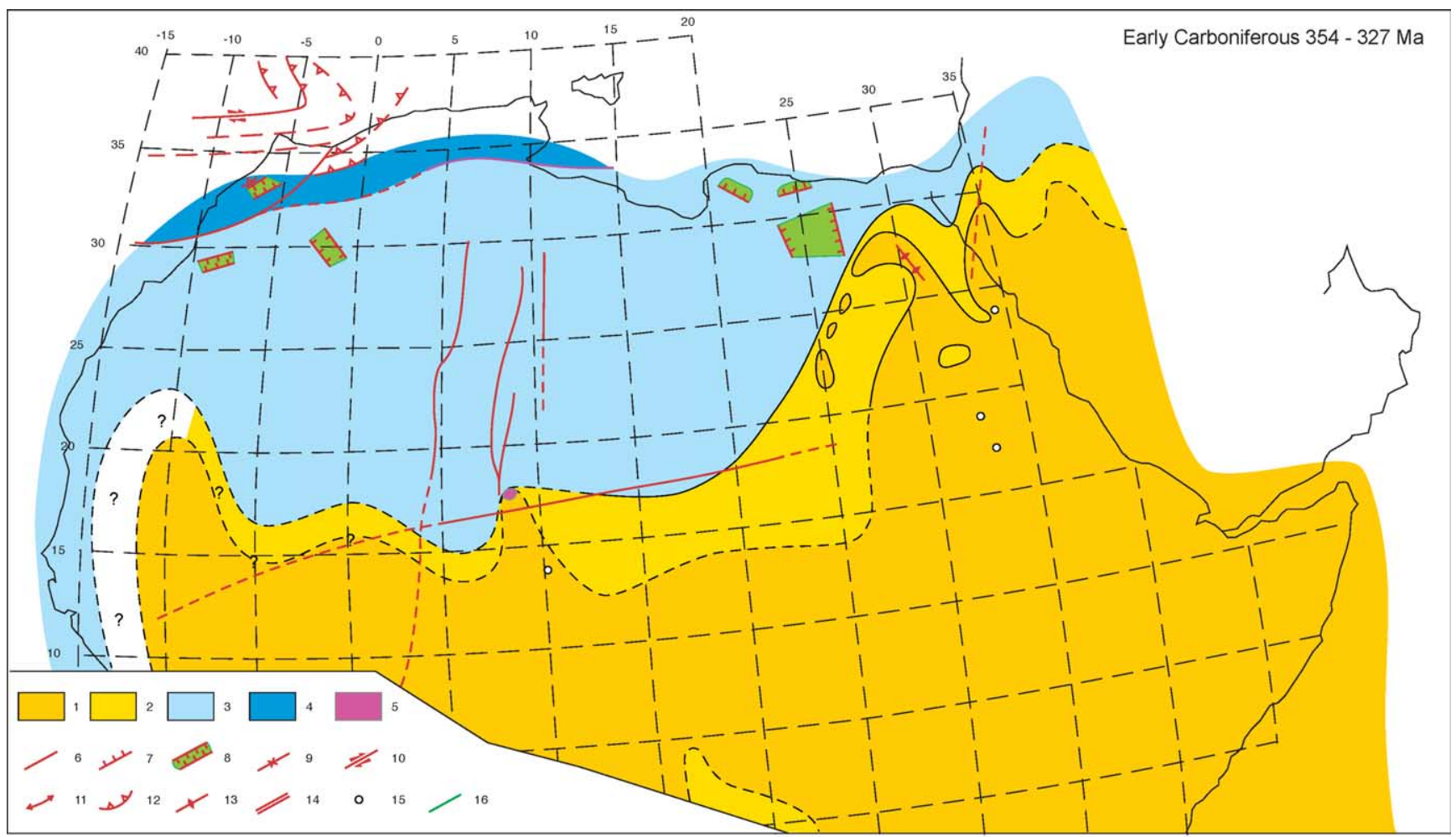

A

Fig. 16A. Early Carboniferous (354-327 Ma) paleogeological map. Same legend as Fig. 6.

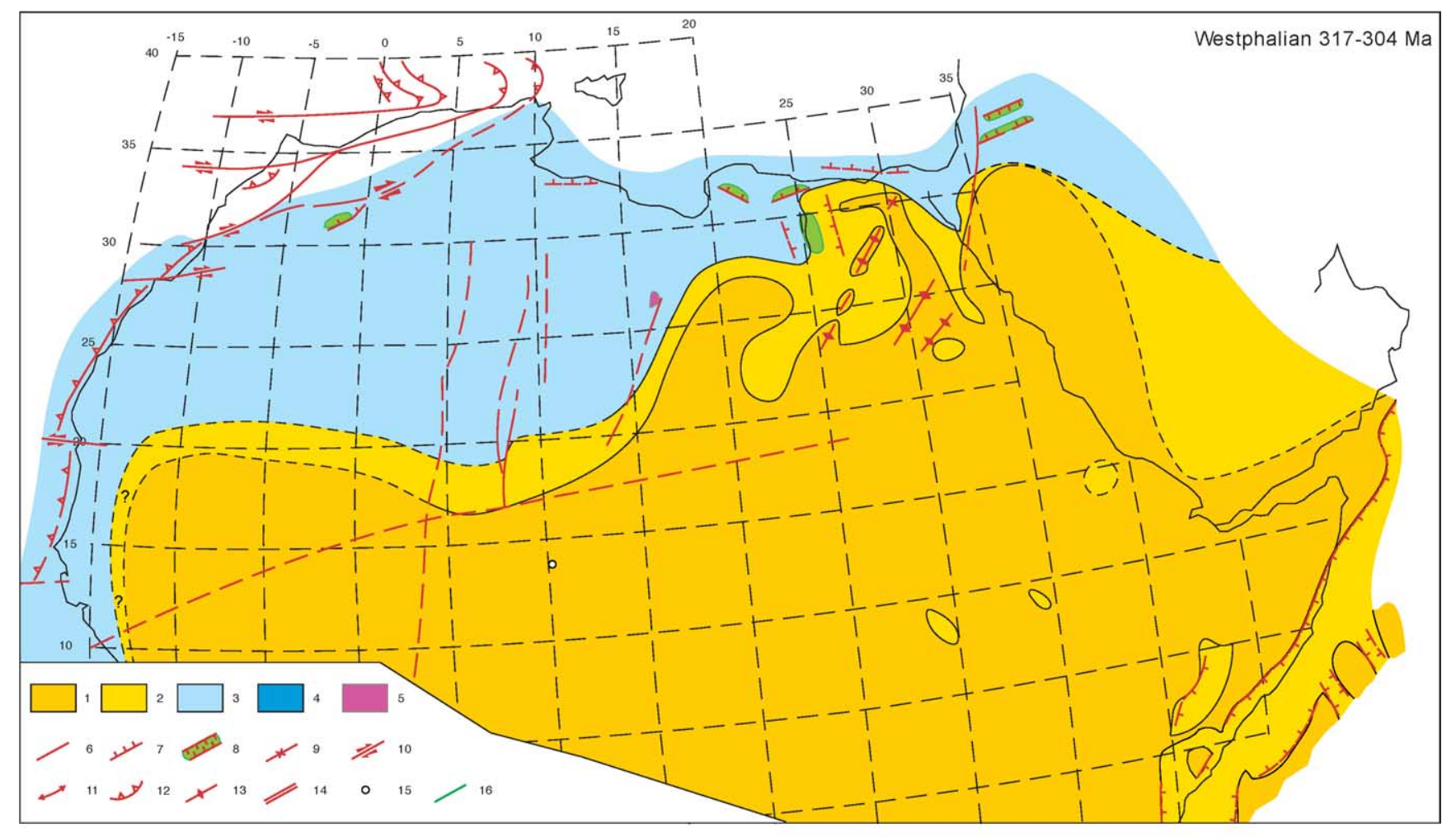

B

Fig. 16B. Westphalian (317-304 Ma) paleogeological map, modified from Guiraud (2001). Same legend as Fig. 6. 


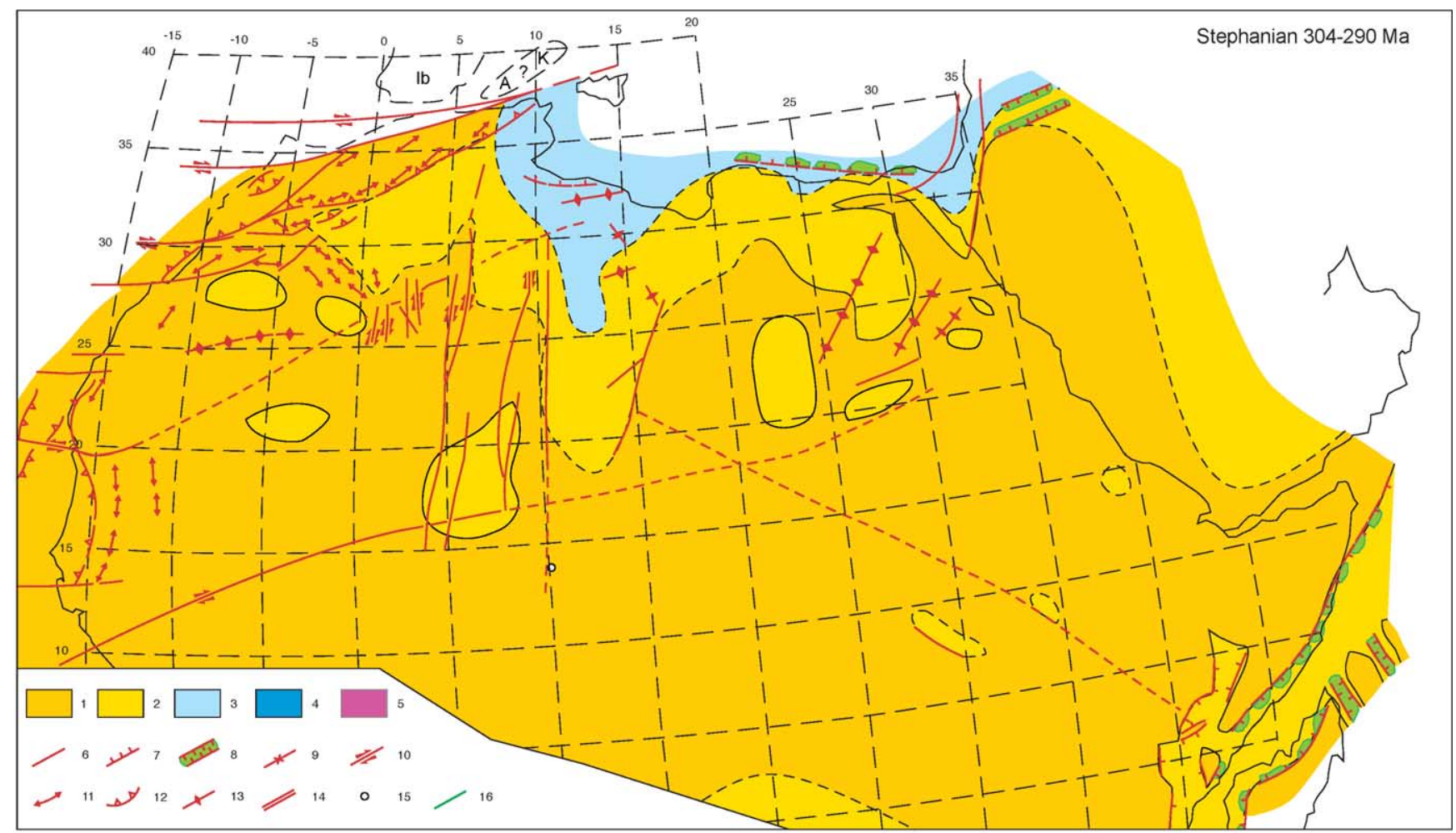

A

Fig. 17A. Stephanian (304-290 Ma) paleogeological map, modified from Guiraud (2001). Same legend as Fig. 6. A, Alboran; Ib, Iberia; K, Kabylies.

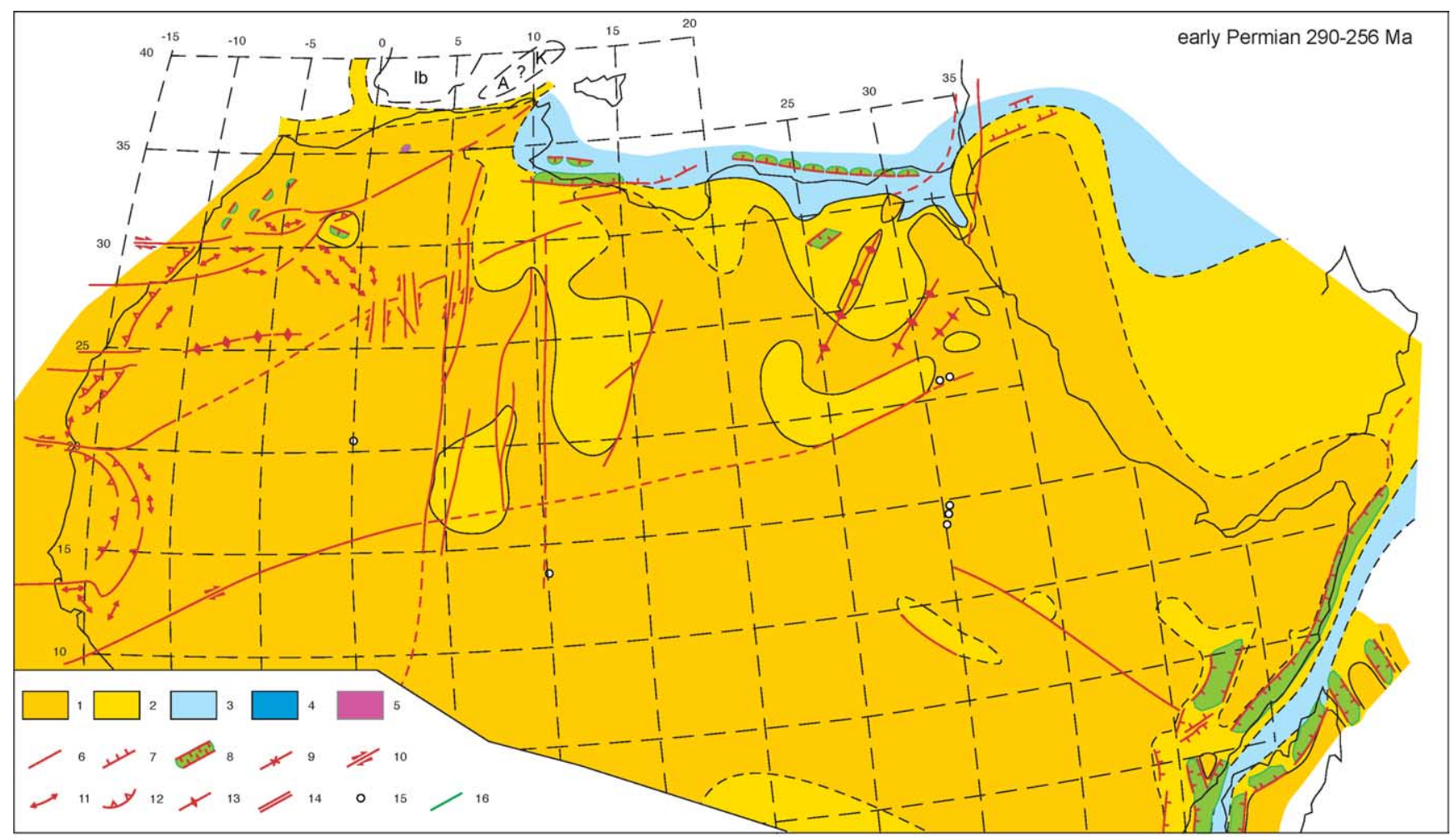

B

Fig. 17B. Early Permian (290-256 Ma) paleogeological map, modified from Guiraud (2001). Same legend as Fig. 6. A, Alboran; Ib, Iberia; K, Kabylies. 


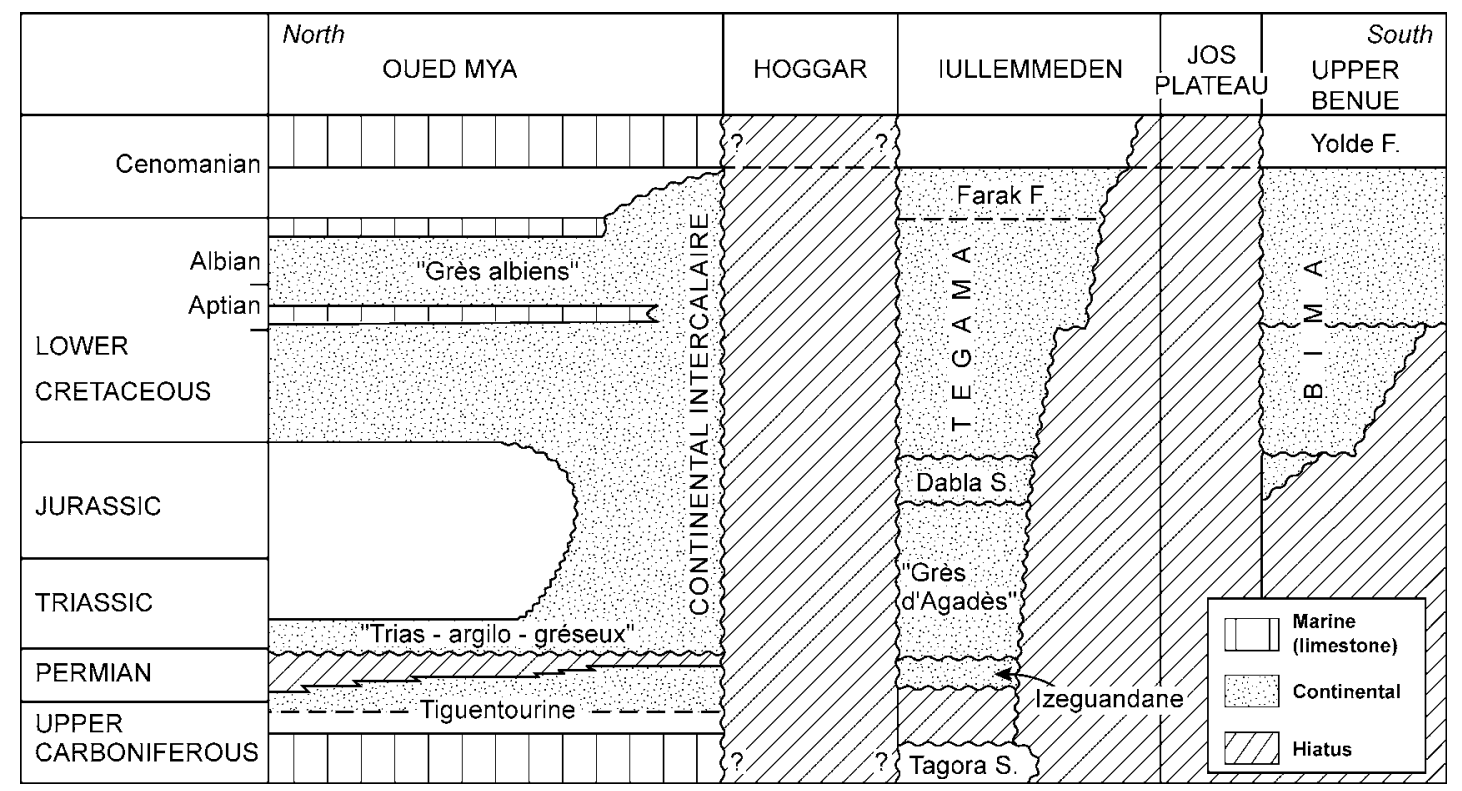

Fig. 18. Correlations of selected series of the "Continental intercalaire" from southern Algeria to the Benue Trough, slightly modified from Lefranc and Guiraud (1990).

Western Africa the main stage of the Hercynian orogenesis (Fig. 17B). Strong folding, thrusting, and metamorphism occurred along the North Algerian-MoroccanMauritanides Belt (reviewed in Piqué, 2001; Hoepffner et al., this issue; Villeneuve, this issue) (Figs. 19 and 20). The Ougarta intra-cratonic fold belt developed (Ziegler et al., 1995), while the interior platform was deformed into a series of folds, saddles, arches, and intervening sag basins (Boote et al., 1998; Guiraud and Bosworth, 1999; Haddoum et al., 2001) (Fig. 21). The most important intra-platform tectonic character corresponds to the active sinistral strike-slip movement of the $\sim \mathrm{N}-\mathrm{S}$ trending fault zones (Fig. 22), accompanied by drag folds and local thrusting (Haddoum et al., 2001). The active dextral movement of

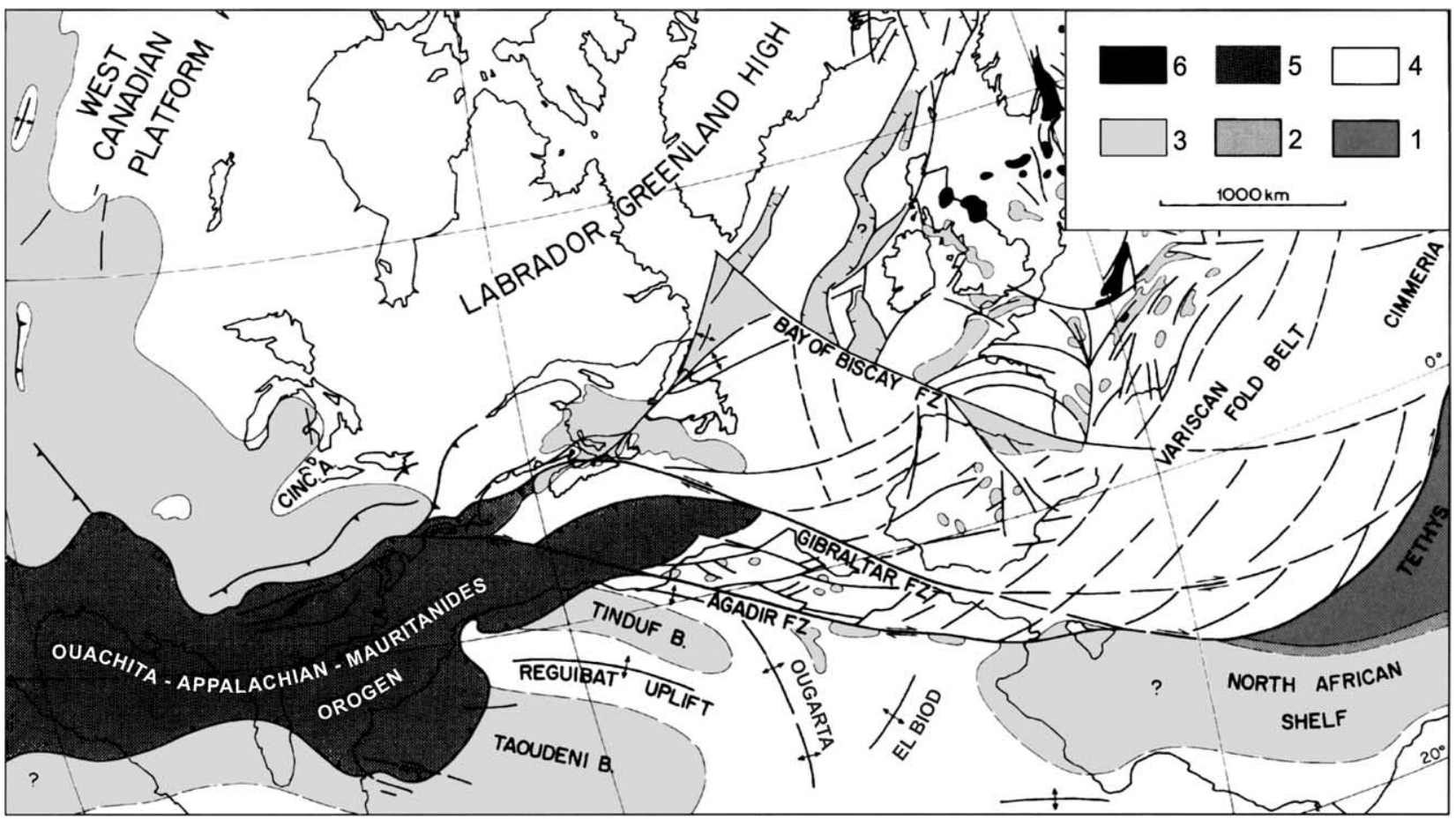

Fig. 19. Schematic tectonic map of the early Permian Variscan Orogen in the western European, northwestern African and eastern North American domains. Simplified after Ziegler (1990). (1) Oceanic basin; (2) deep marine basin; (3) shallow marine-continental basin; (4) cratonic high; (5) active fold belt; (6) plateau basalts. 


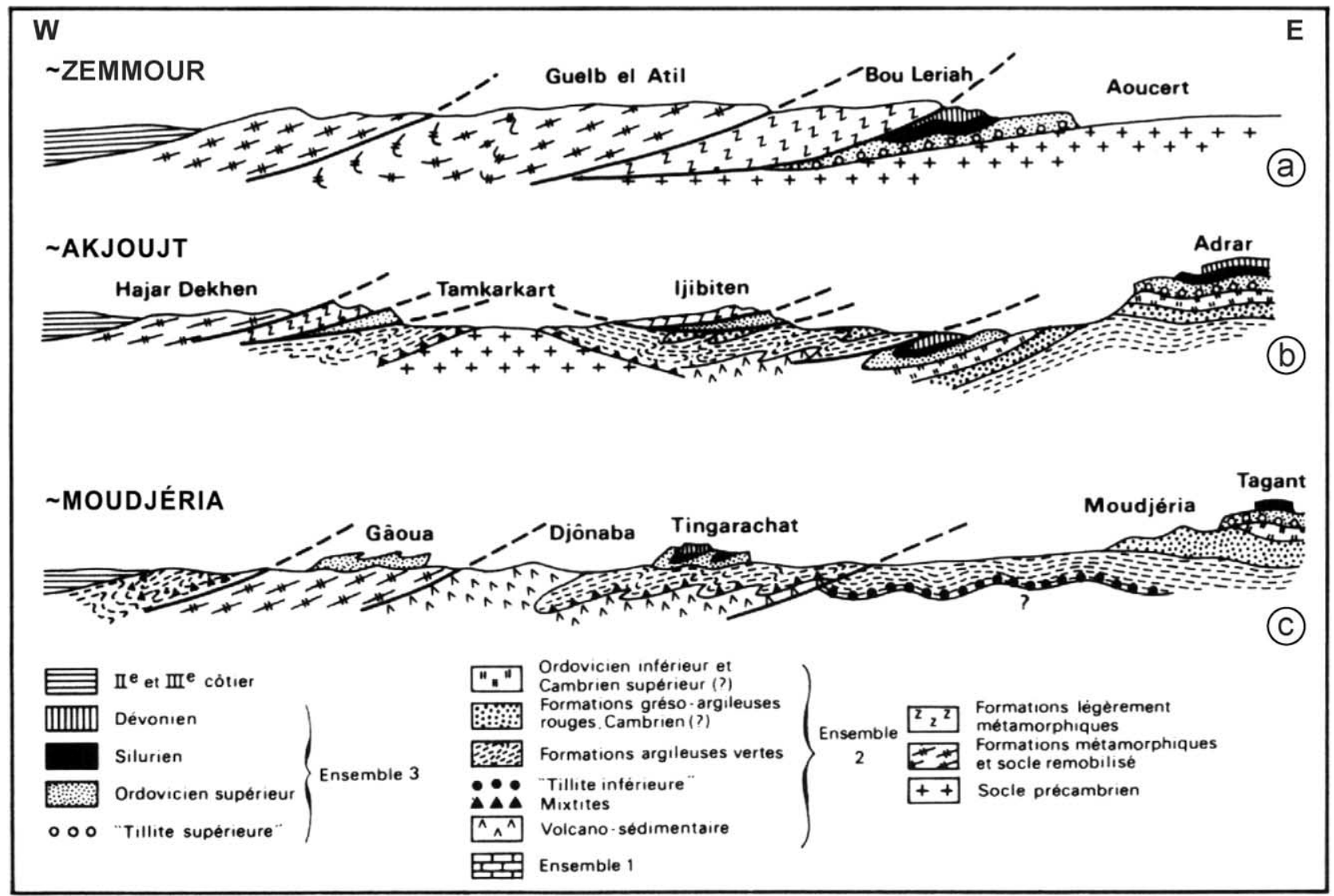

Fig. 20. Schematic geological cross-sections through the Mauritanides thrust belt, after Deynoux (1983).

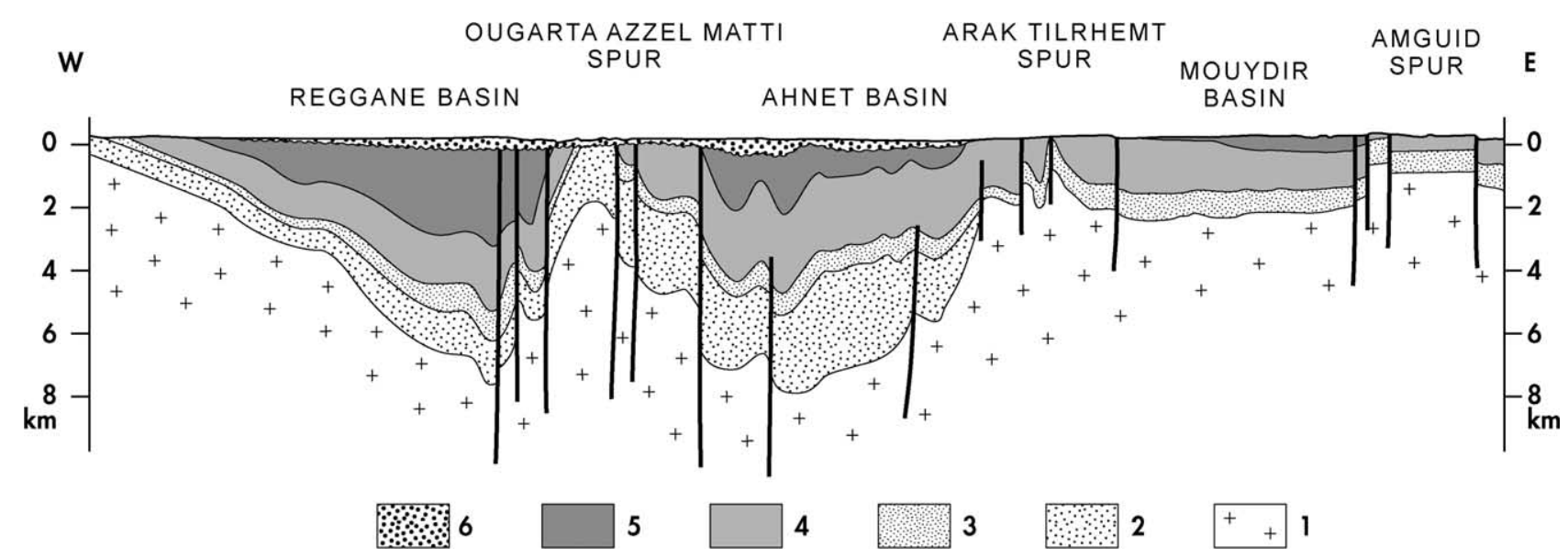

Fig. 21. Schematic geological cross-section of the northwestern Hoggar Variscan fold belt, slightly modified from Schlumberger-Sonatrach (1995). (1) Pan-African basement; (2) Cambrian; (3) Ordovician; (4) Silurian-Devonian; (5) Carboniferous-earliest Permian; (6) Mesozoic.

the ENE-WSW trending south Atlasic fault zone can also be stressed (Houari and Hoepffner, 2003). Diachronism in the age of the main events is observed, accompanied by a change in the shortening directions. Latest Carboniferous ages and NW-SE shortening characterize northwesternmost Africa (Morocco, northern Algeria), while earliest Permian ages and E-W to ENE-WSW shortening characterize the Mauritanides Belt and southern Algeria (Had- doum et al., 2001). This evolution appears as a result of the progressive closure of the Paleotethys Ocean, from the North toward the South (Ziegler, 1989; Matte, 2001), and of the clockwise rotation of the African plate during the Carboniferous to Early Permian times (Merabet et al., 1990).

Early Permian rift basins similarly formed diachronously along the northernmost African margin, from 


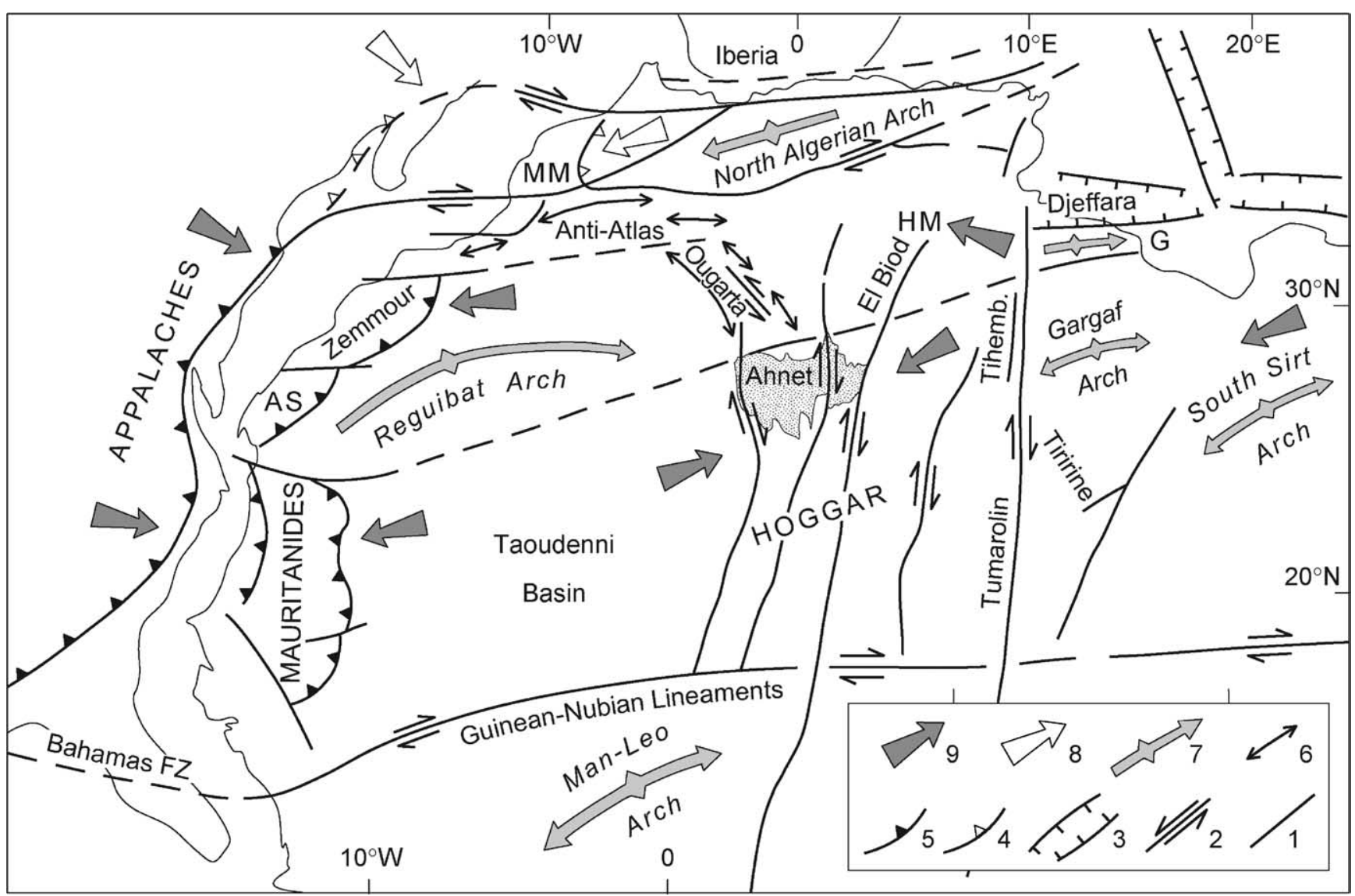

Fig. 22. Early-Permian intra-plate deformation of the Saharan platform forming the foreland of the Mauritanides Orogen, modified from Haddoum et al. (2001). (1) Major fault; (2) major strike-slip fault; (3) rift; (4) Late Carboniferous thrust belt; (5) Early Permian thrust belt; (6) Late carboniferous-Early Permian fold belt; (7) major upwarped arch; (8) Late Carboniferous shortening direction; (9) Early Permian shortening direction. The stippled area corresponds to the Ahnet-Mouydir Basin. AS, Adrar Soutouf; D, Dahar Arch; G, Gharian Arch; HM, Hassi Messaoud; IB, Illizi Basin; MM, Moroccan Meseta.

Morocco to Egypt (Fig. 17B). These were infilled by thick series of continental (Morocco-Algeria), mixed (Egypt), or marine sediments (S Tunisia-NW Libya) (Fig. 23), whereas only thin and local continental series were deposited along the southern Sahara platform (e.g., in the Tim Mersoi Basin of northern Niger). Rifting increased throughout the Permian, while subsidence affected the Eastern Mediterranean margin (Fig. 24) in conjunction with the opening of the Neotethys (Stampfli and Borel, 2002). Along Eastern Africa, the Karoo rifts developed and a narrow, shallowsea arm invaded from Early Permian times the depressed corridor developing between the Horn of Africa and the Madagascan-Indian promontory of Eastern Gondwana (reviewed in Dercourt et al., 1993; Guiraud and Bellion, 1995). Shallow water evaporites and carbonates were deposited over the central Arabian platform during the Late Permian (Ziegler, 2001).

A general tensional regime prevailed during the late Early Permian and the Late Permian that favored magmatism, particularly in the northwestern African Nubia province, which was intruded by numerous alkaline anorogenic complexes and consequently again uplifted (Wilson and Guiraud, 1998; Guiraud and Bosworth, 1999). Minor tectonic activity was registered by the Permian-Triassic transition along Northern Africa, entailing slight uplifts, arching or block tilting, and local strike-slip rejuvenation of faults (Echikh and Sola, 2000). This could represent the far field effect of stronger deformation then occurring southwards in the Zaire Basin (Daly et al., 1992) and more intensively along the Cape Fold Belt and forelands (Hälbich et al., 1983; Shone and Booth, this issue).

\section{Mesozoic evolution}

\subsection{Triassic}

The Triassic formations unconformably overlie the Permian or older ones (Figs. 25-27), yet few changes occurred in the paleogeography from Late Permian to Early Triassic (Figs. 24 and 28A). The main change consists in the initiation of the transgression of the Neotethys over the northwesternmost African margin, up to the Algerian-Moroccan borders, that produced terrigenous to mixed marine sedimentation (Courel et al., 2000, 2003). This transgression, favored by active rifting, developed during the Middle and mainly Late Triassic, as shallow 


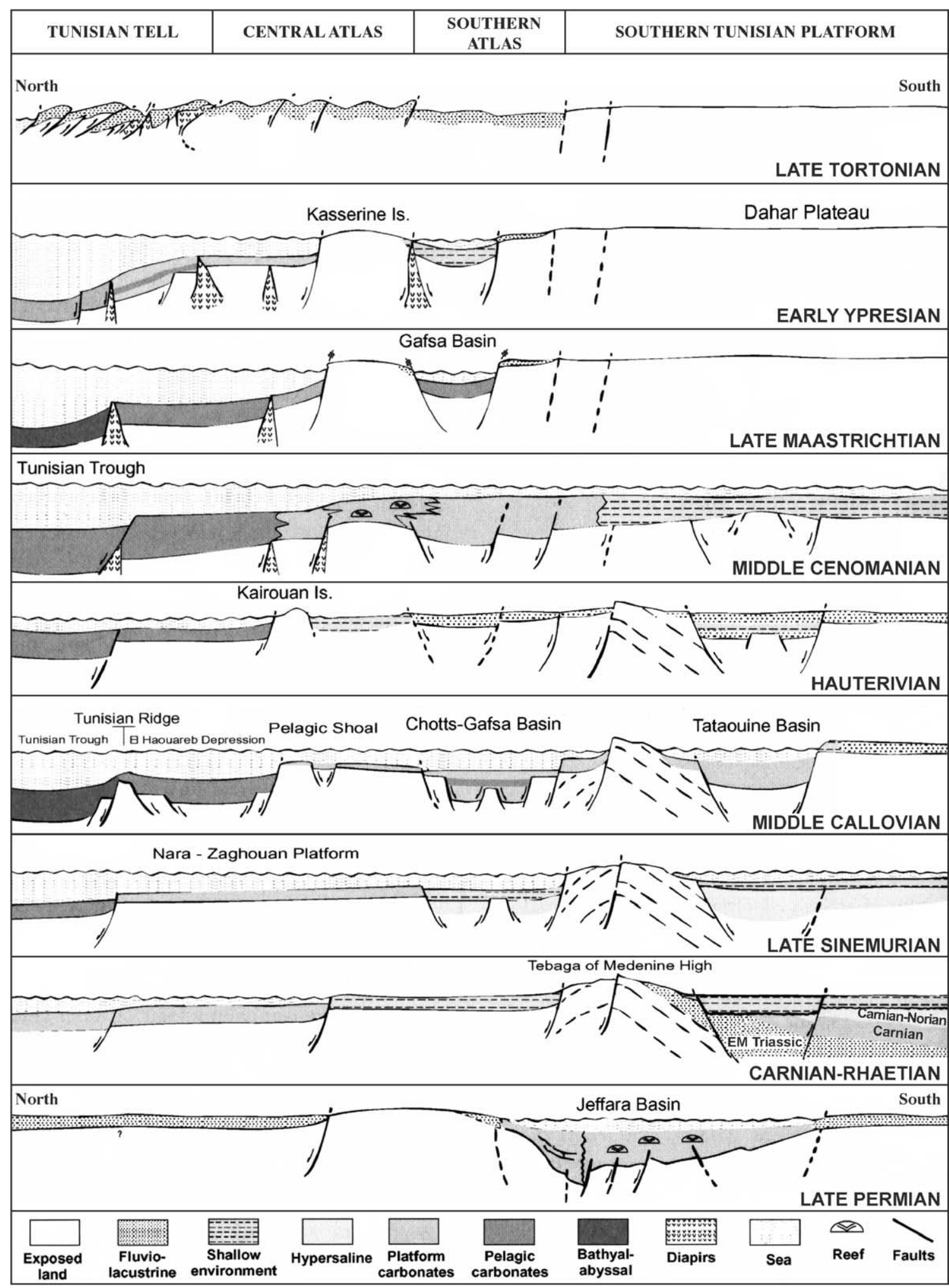

Fig. 23. Interpretative $\mathrm{N}-\mathrm{S}$ sections showing relationship between sedimentation and tectonic in Tunisia from Late Permian to Tortonian times, after Bouaziz et al. (2002).

sea gulfs or channels extended over Algeria, Morocco and then between the West African and North American margins up to the Guinea and Demerara plateaus (Figs. 28B, 29-32). The development of carbonates and evaporitic platforms characterizes these stages, the latter covering in particular the narrow, evolving proto-Central Atlantic Ocean (see detailed maps and overviews in Dercourt et al., 1993, 2000; Courel et al., 2000, 2003; Davison, this 


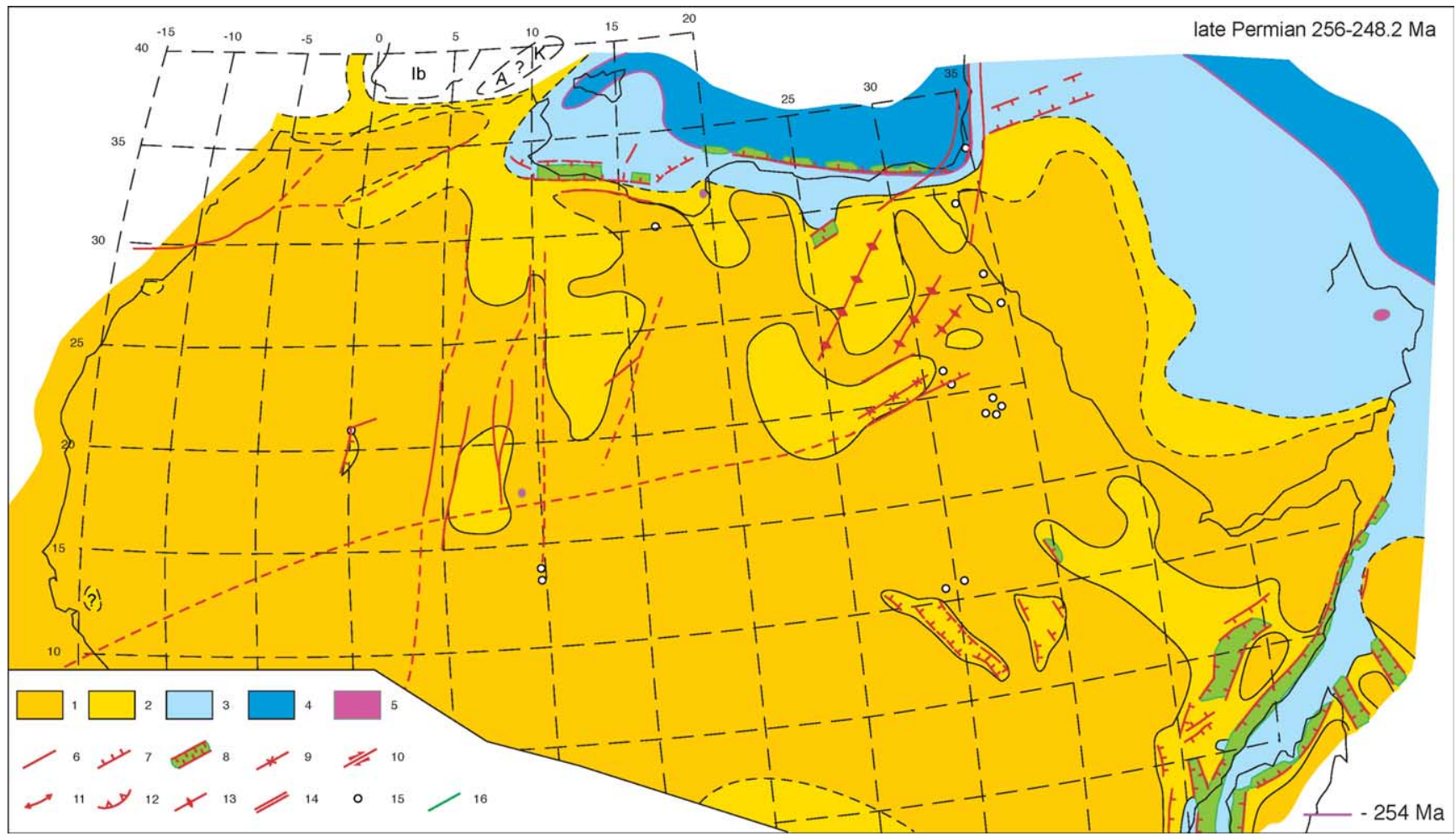

Fig. 24. Late Permian (256-248.2 Ma) paleogeological map, modified from Guiraud (2001). Same legend as Fig. 6. A, Alboran; Ib, Iberia; K, Kabylies.

NW

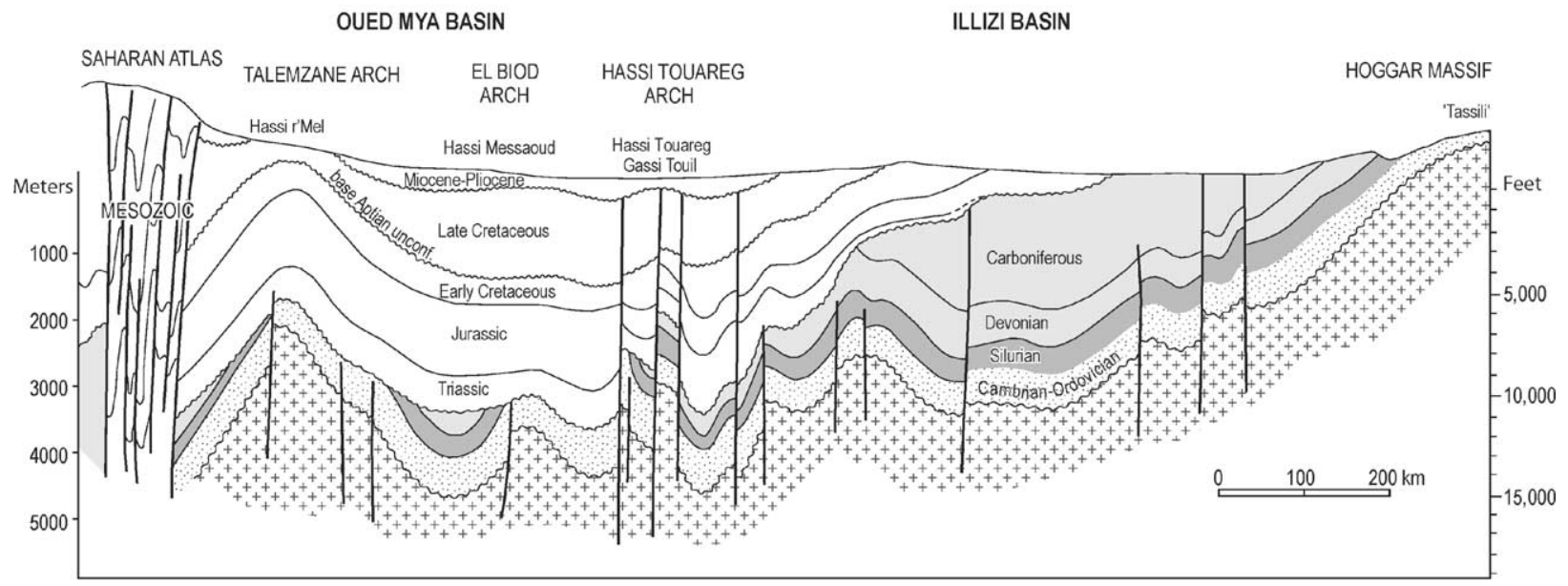

Fig. 25. Schematic structural cross-section across the Oued Mya and Illizi basins, Algerian Sahara, after Boote et al. (1998). issue). These evaporites would play an active role later on, as they underwent diapirism and/or favored thrusting along the Alpine Belt.

The Eastern Mediterranean African and Levant margins were also affected by tectonic instability, increasing from Middle Triassic times and underscored by block tilting and local uplifts (Guiraud and Bosworth, 1999). This activity was connected with the development of the Eastern Mediterranean Basin then undergoing continental crustal thinning or more probably initiation of spreading (see discussions by Robertson et al., 1996; Stampfli et al., 2001;
Stampfli and Borel, 2002). Effusion of flow basalt accompanied rifting or faulting all along the Mediterranean margins, including the northeastern Sirt Basin (Wilson and Guiraud, 1998; Guiraud, 2001).

In the intra-continental domain, large fluviatile lacustrine basins remained active, flooding northwards as for the Murzuq and Dakhla basins, or endoreic as in the Tim Mersoi and al Kufrah-Lakia basins. Faulting and local uplifting of basin shoulders favored terrigenous sedimentation in these basins. Also noticeable is the strong rejuvenation of alkaline magmatic activity registered 


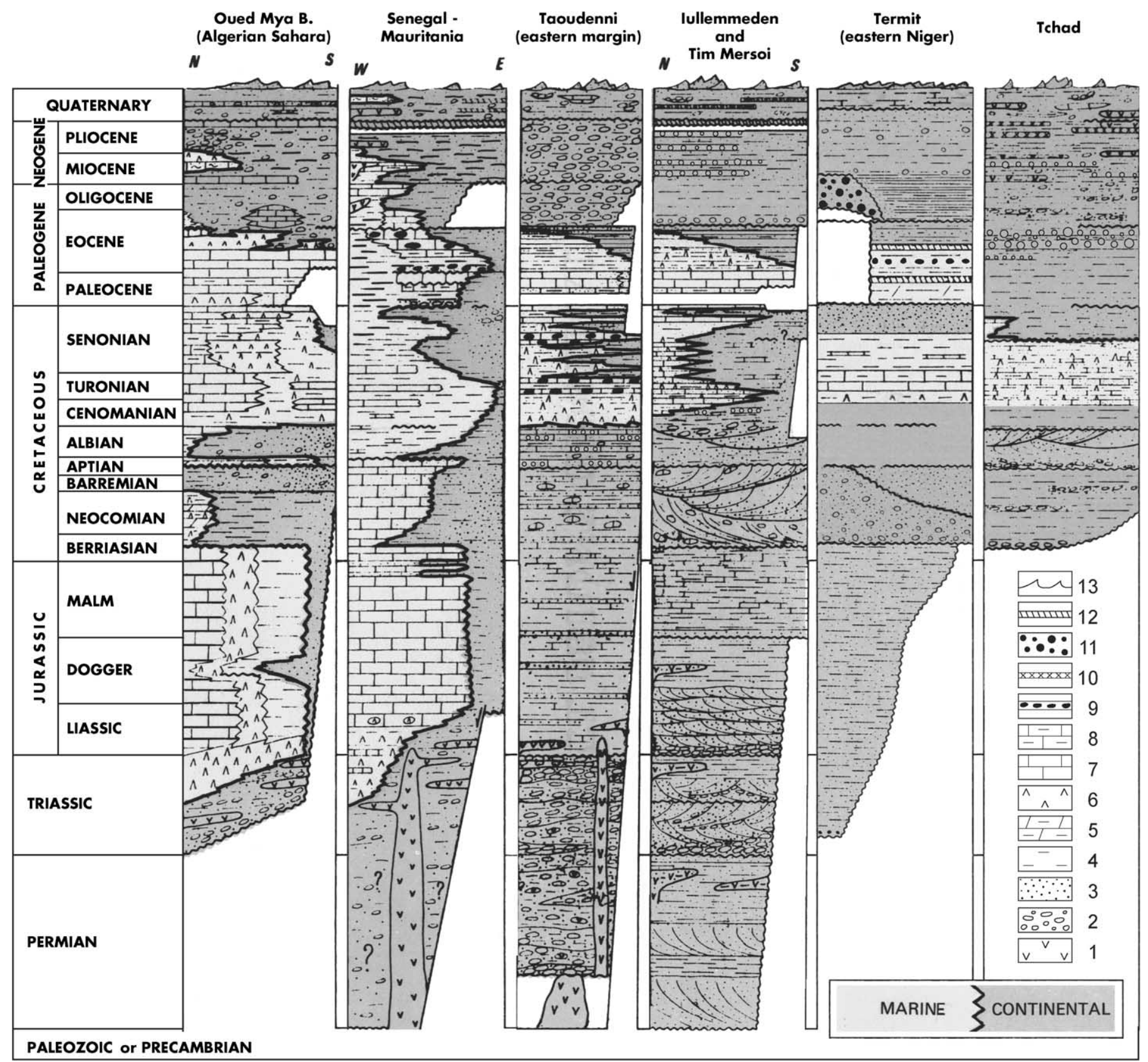

Fig. 26. Lithostratigraphic correlation chart of Permian to Recent sediments of some western African, northern African and central African basins, modified from Bellion (1989). Lithologies: (1) volcanics; (2) conglomerates; (3) sandstones; (4) clays, shales; (5) dolomitic shales; (6) evaporites; (7) limestones; (8) clayey limestones; (9) flints, cherts; (10) diatomites; (11) ferruginous oolites; (12) laterites; (13) sand dunes.

during Middle Triassic times in the Nubia and Kordofan provinces of southern Egypt-central Sudan (Vail, 1989; Höhndorf et al., 1994).

Around the Horn of Africa, rifting developed in the Karoo-type basins (Mbede, 1987; Winn et al., 1993; Guiraud and Bellion, 1995; Guiraud, 2001) (Fig. 33). A narrow sea-arm sporadically occupied the channel extending between the northeastern African and MadagascanSeychelles-India margins, exhibiting terrigenous to mixed sedimentation (Dercourt et al., 1993; Guiraud, 2001). A marginal marine platform developed over eastern Saudi
Arabia during the Middle Triassic (Ziegler, 2001) and regressed in the Late Triassic, predating the emersion of a large domain by the end Triassic (Fig. 34).

By the end Triassic, gentle tectonic activity was registered along the African-Arabian Neotethyan margin, as demonstrated by frequent unconformities and gaps in the series (Alsharan and Nairn, 1997; Guiraud and Bosworth, 1999). This deformation represents the distal effects of the "Eo-Cimmerian" orogenic event, which affected the Black Sea area (Nikishin et al., 2001) and was of major importance in Asia (Sengör, 1990). 


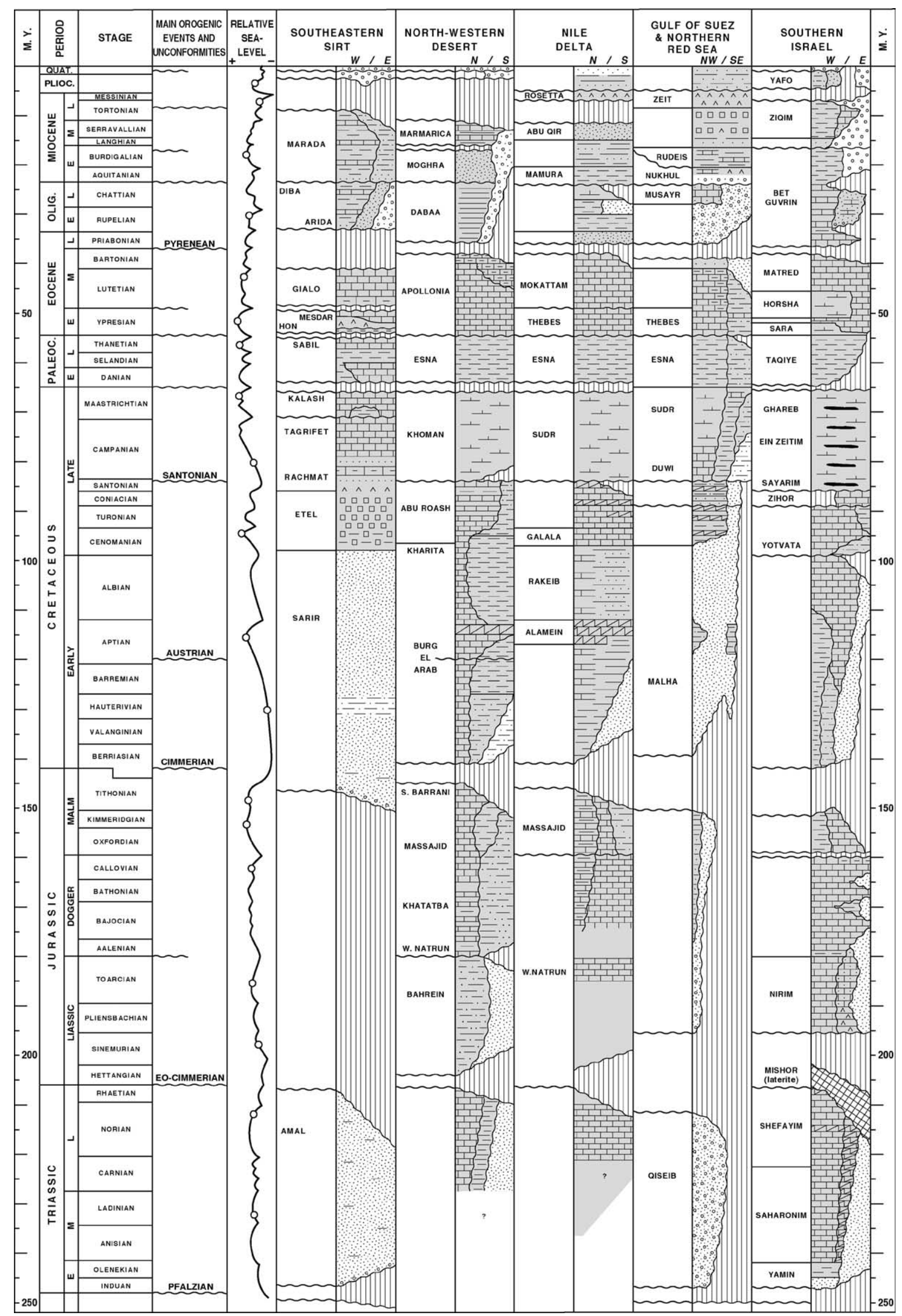

Fig. 27. Lithostratigraphic and tectonic correlation chart of Mesozoic and Cenozoic sediments of some northeastern African and northwestern Arabian basins, after Guiraud and Bosworth (1999). Sea level curve is simplified from Schandelmeier and Reynolds (1997). Grey shading indicates marine formations. Hatching indicates stratigraphic hiatuses (non-deposition or erosion). Lithologies as Fig. 10. 


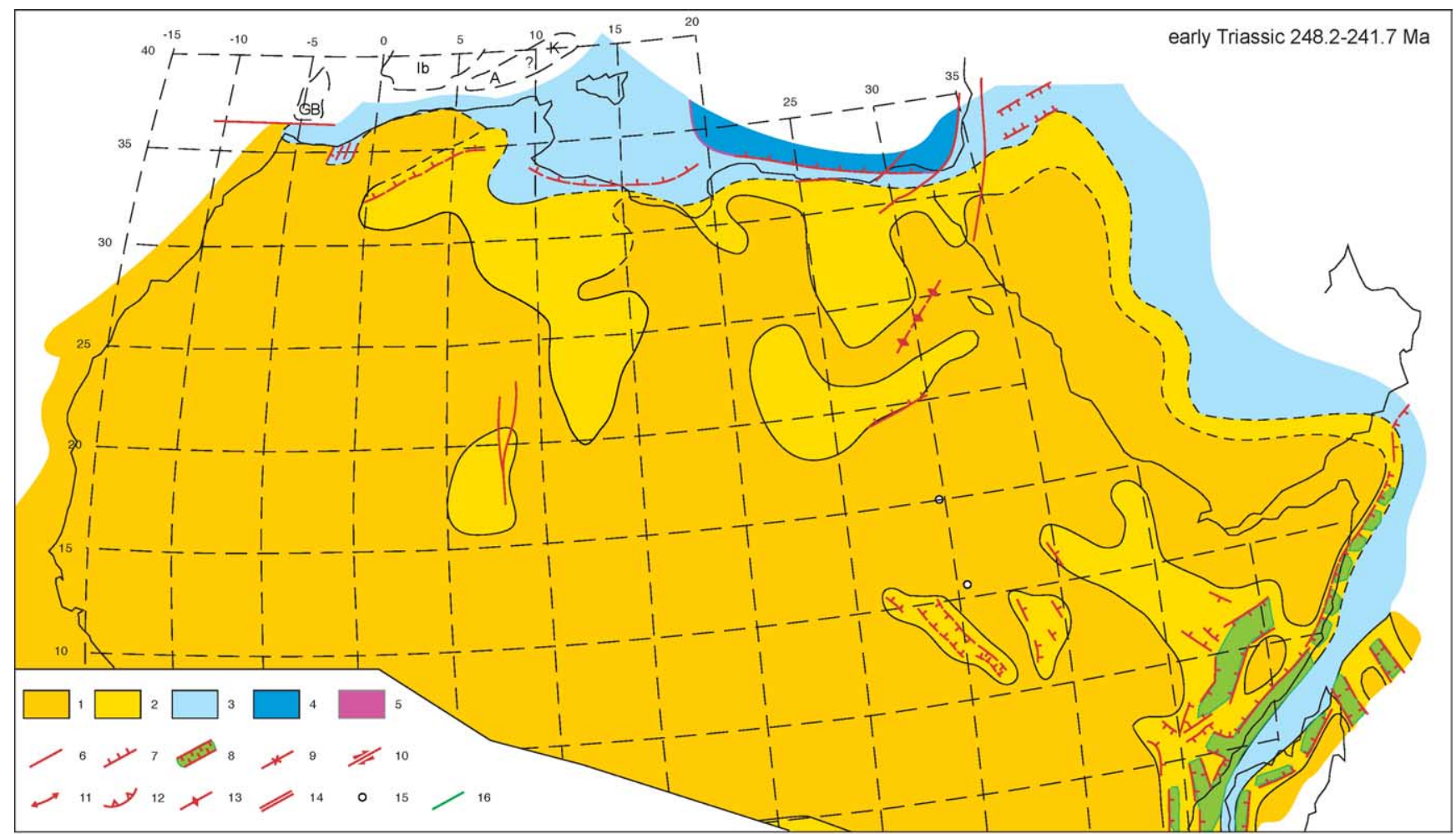

A

Fig. 28A. Early Triassic (248.2-241.7 Ma) paleogeological map, modified from Guiraud (2001). Same legend as Fig. 6. A, Alboran; GB, Great Bank; Ib, Iberia; K, Kabylies.

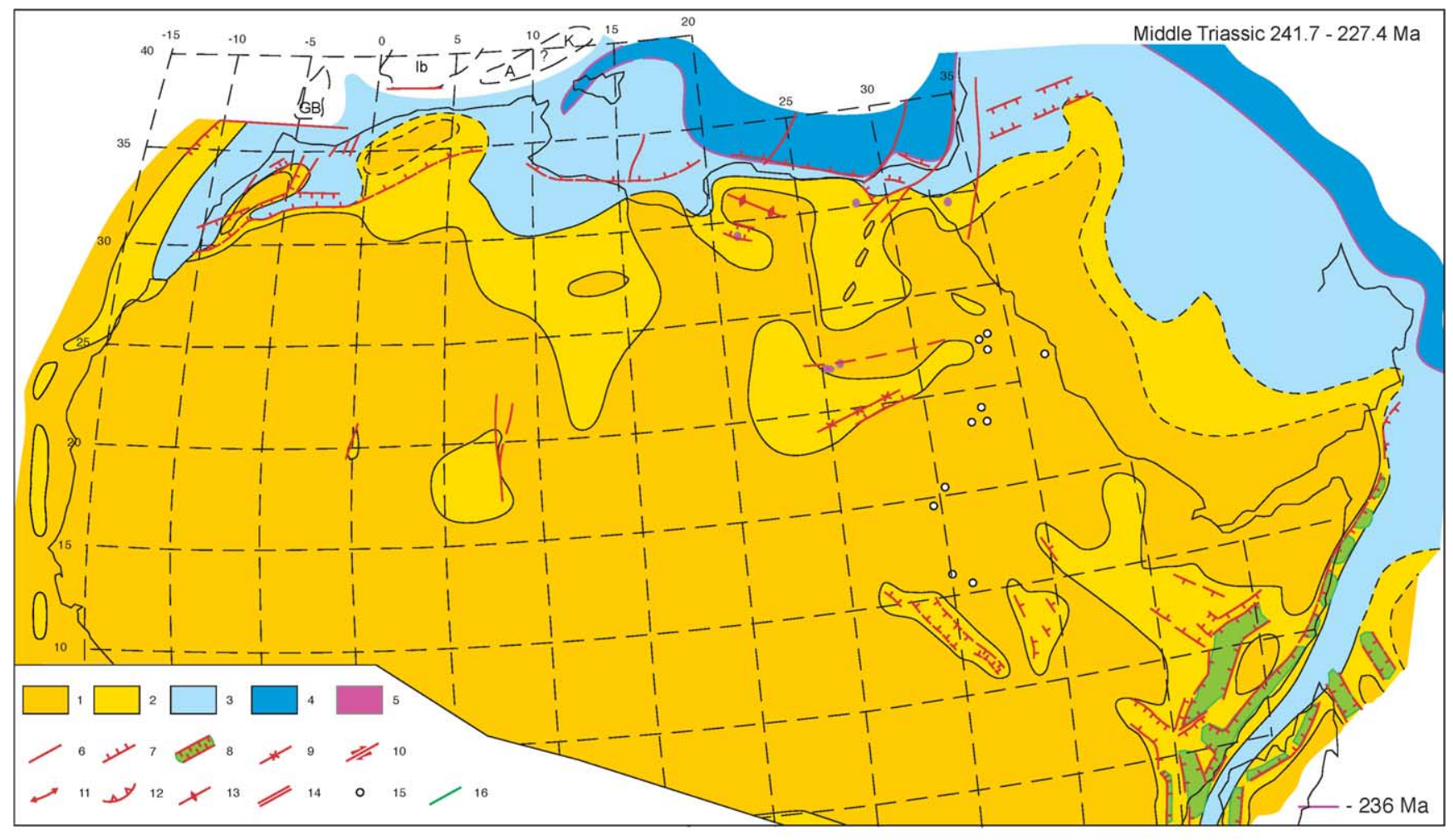

B

Fig. 28B. Middle Triassic (241.7-227.4 Ma) paleogeological map, modified from Guiraud (2001). Same legend as Fig. 6. 


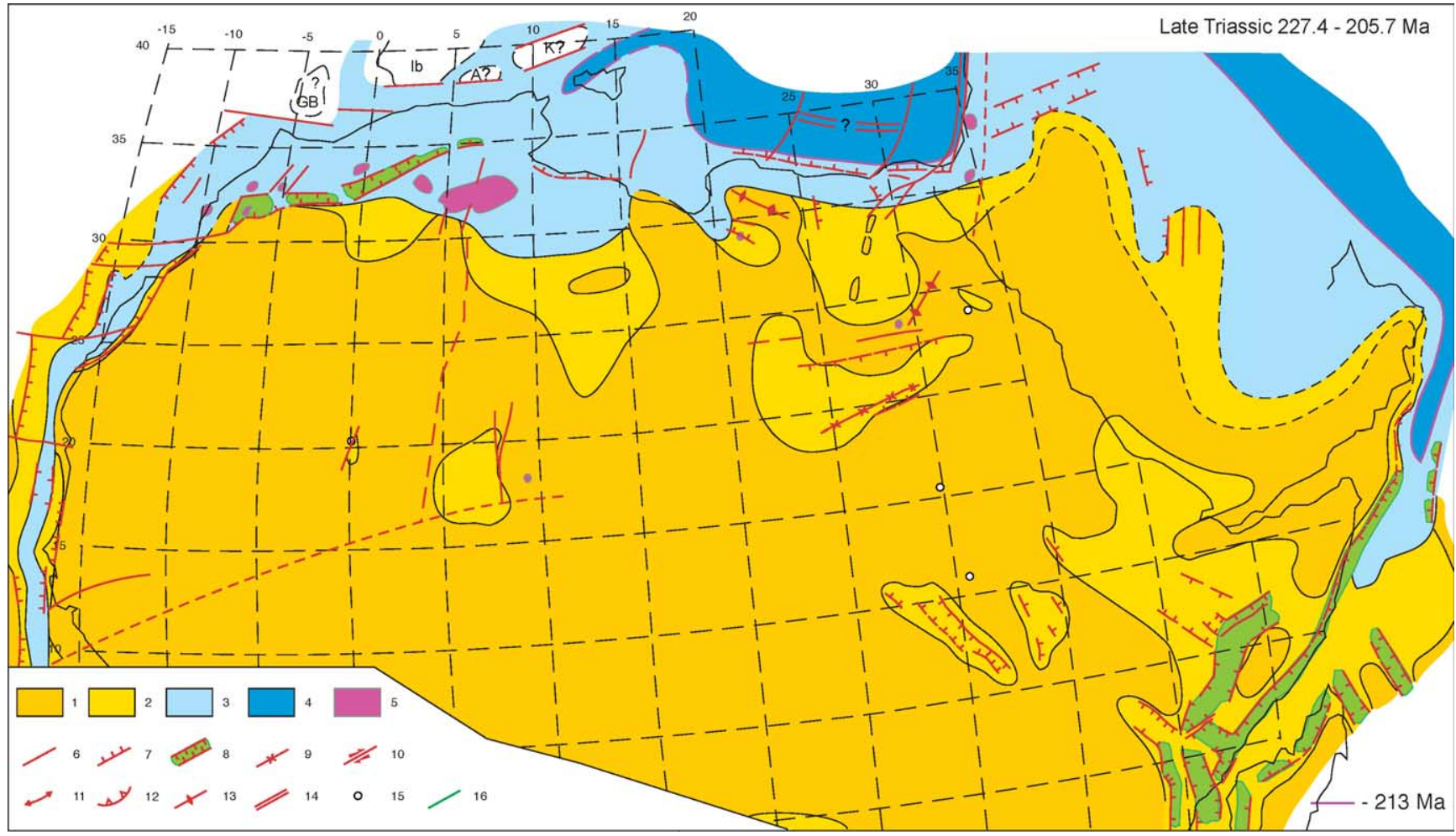

Fig. 29. Late Triassic (227.4-205.7 Ma) paleogeological map, modified from Guiraud (2001). Same legend as Fig. 6.

\subsection{Jurassic}

The Jurassic times are marked by several geodynamic and magmatic characteristics or events (Figs. 35A, 35B, 36A, 36B):

- the development of rifts or subsident basins along the northwestern African, the eastern African, and, more locally, the Egyptian margins;

- the initiation of the Western Mediterranean, Central Atlantic, and Somali Basin oceanic domains, followed by the development of stable continental margins around Northern Africa;

- fluctuating global sea levels, including a significantly high level during the Early Kimmeridgian;

- reduced intra-continental fluviatile-lacustrine basins;

- the development of the Central Atlantic magmatic tholeiitic province in the earliest Liassic; and

- the development of the alkaline anorogenic intrusive Nubia and Jos Plateau (Nigeria) provinces in the Late Jurassic.

We shall summarize hereafter the geological evolution of Northern and Central Africa during Early, Middle and then Late Jurassic times. We pay special attention to the northwestern Africa Maghrebian alpine domain, located in the Western Mediterranean/Central Atlantic confines. This area was consequently strongly affected by transtensional (and locally transpressive) movements that resulted in the development of a mosaic of micro-blocks that often persisted up to Recent times and strongly influence the complex present-day geology and geography of this domain.

\subsubsection{Liassic}

Block faulting continued during the Liassic along the Eastern Mediterranean margin (Guiraud and Bosworth, 1999; Stampfli et al., 2001) (Figs. 35A and 37). A marginal marine gulf invaded the northern Dakhla Basin (NW Egypt) in the Liassic, while a narrow carbonate platform developed along the margin.

Westwards, a marginal marine sea invaded the Algerian-Tunisian Saharan platform where thick evaporites were deposited. Rifting developed along the Saharan Atlas, the High Atlas, the Middle Atlas, and the Tellian Trough (Fig. 31). Thick marl series formed in these subsiding basins, while carbonate platforms covered the shoulders of the grabens and the Oranese High Plateaus (Vially et al., 1994; Elmi et al., 1998; Cattanéo et al., 1999; Thierry et al., 2000; Bouaziz et al., 2002; Laville et al., 2004). The Moroccan Meseta and the central High Atlas remained emergent lands connected to the large African Continent. Frequent tholeiitic basaltic flows and pyroclastic deposits were emplaced in Morocco (Fiechtner et al., 1992) and northwestern Algeria (Lapierre et al., 1984), probably related to the development of the Central Atlantic Magmatic Province (see below).

Along the Central Atlantic margin, the Late Triassic N$\mathrm{S}$ trending rifts developed up to the Pliensbachian between the Newfoundland-Azores transtensional fault zone and 

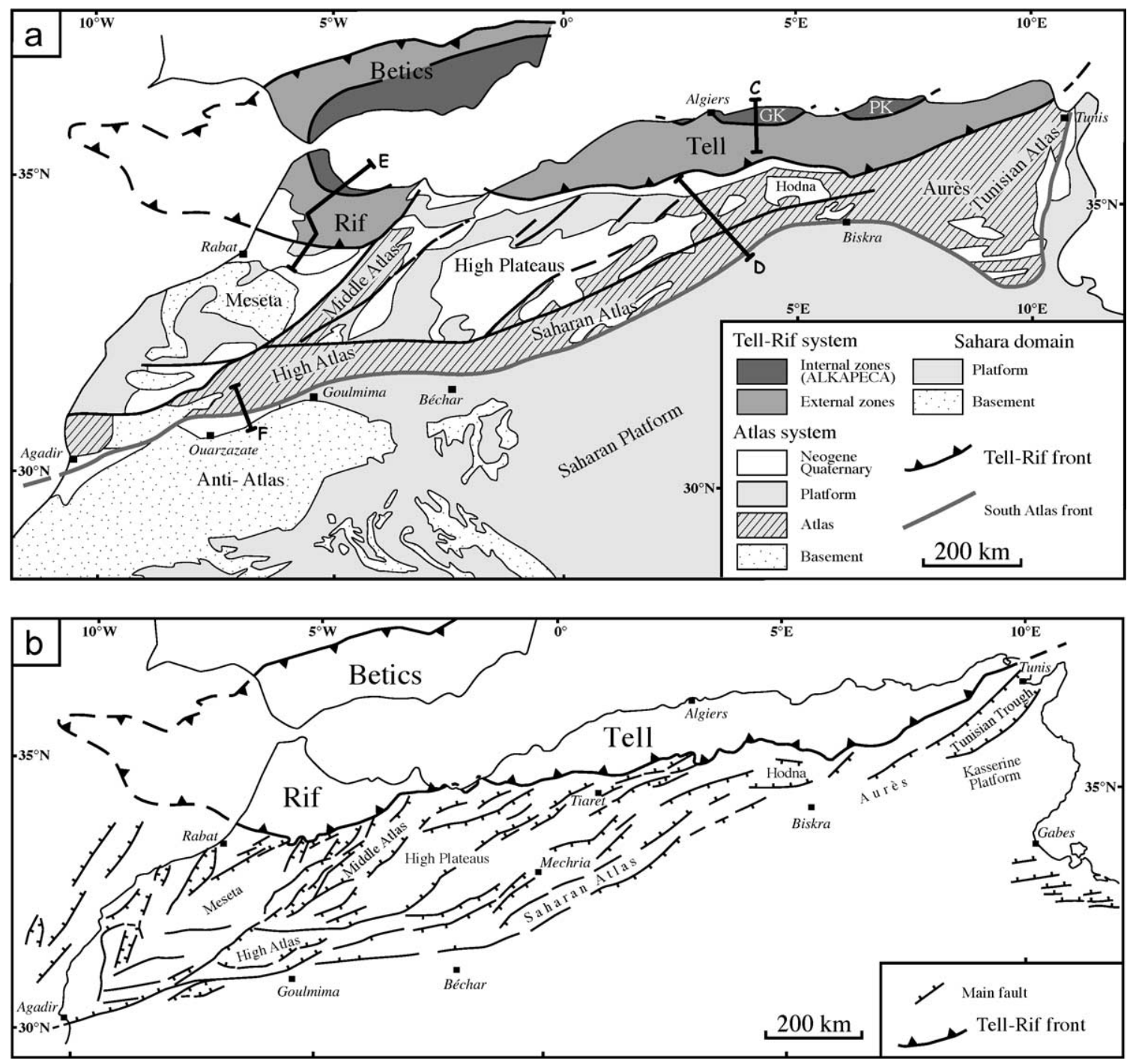

Fig. 30. (a) Structural map of Alpine northwestern Africa showing the main domains. C, D, E, F location of geological cross-sections of Fig. 67. GK, Grande Kabylie; PK, Petite Kabylie. (b) Faults network linked to the Tethyan rifting episode in the Alpine foreland of northwestern Africa. Slightly modified after Frizon de Lamotte et al. (2000).

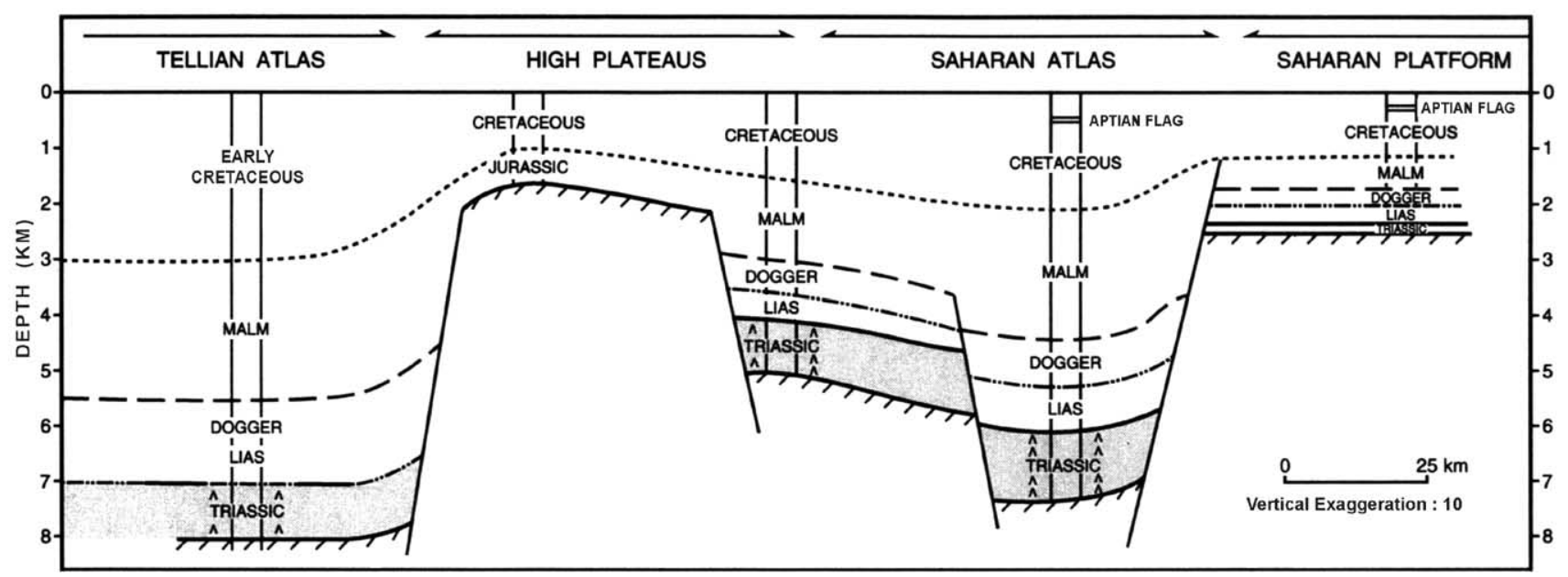

Fig. 31. Schematic cross-section from the Tellian Atlas to the Saharan platform for Triassic to Early Cretaceous times. Slightly modified from Vially et al. (1994). 

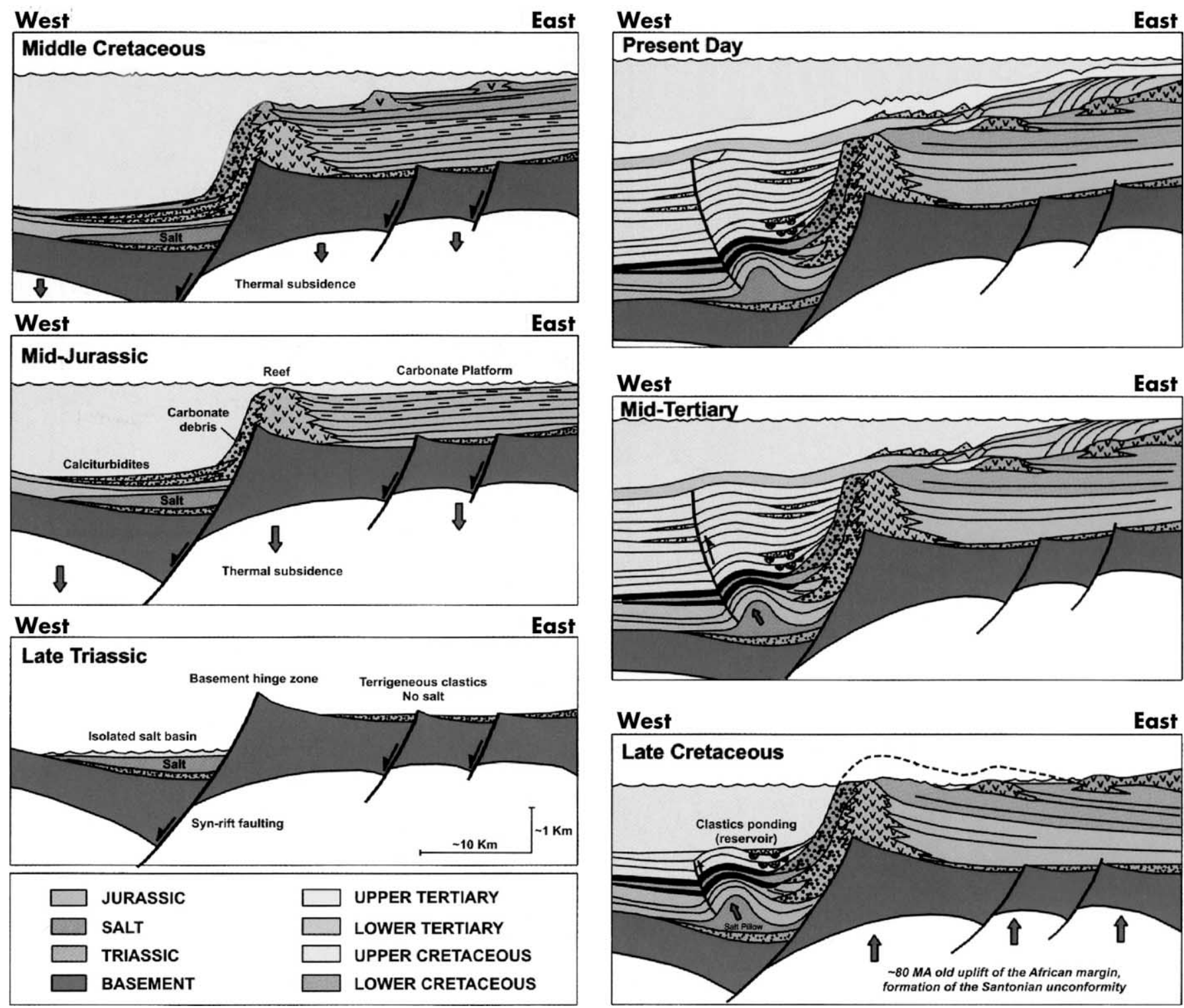

Fig. 32. Sequential restoration sketch of the Senegal Atlantic margin, slightly modified from Tari et al. (2003).

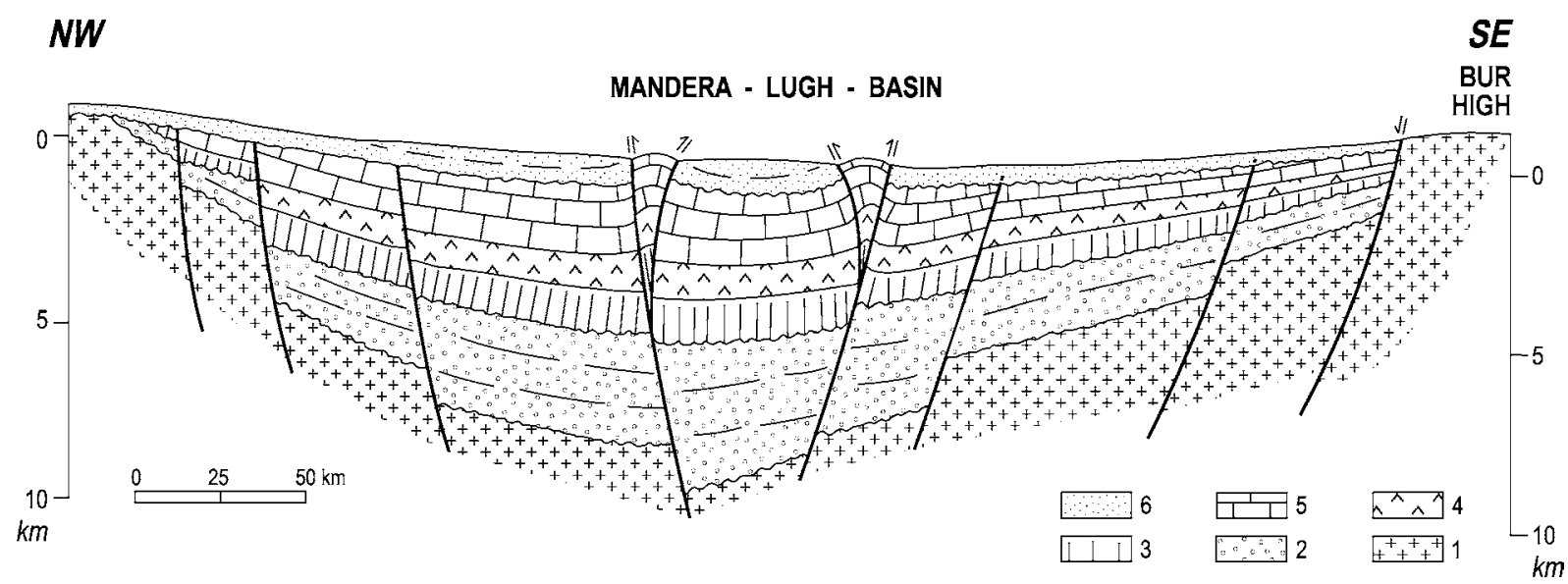

Fig. 33. Schematic geological cross-section along the Mandera-Lugh Basin (Kenya-Somalia-Ethiopia confines). Modified from Mbede (1987), Guiraud and Bosworth (1997) and Ali Kassim et al. (2002). (1) Precambrian basement; (2) Karoo; (3) Liassic; (4) Dogger; (5) Late Jurassic; (6) Cretaceous. 


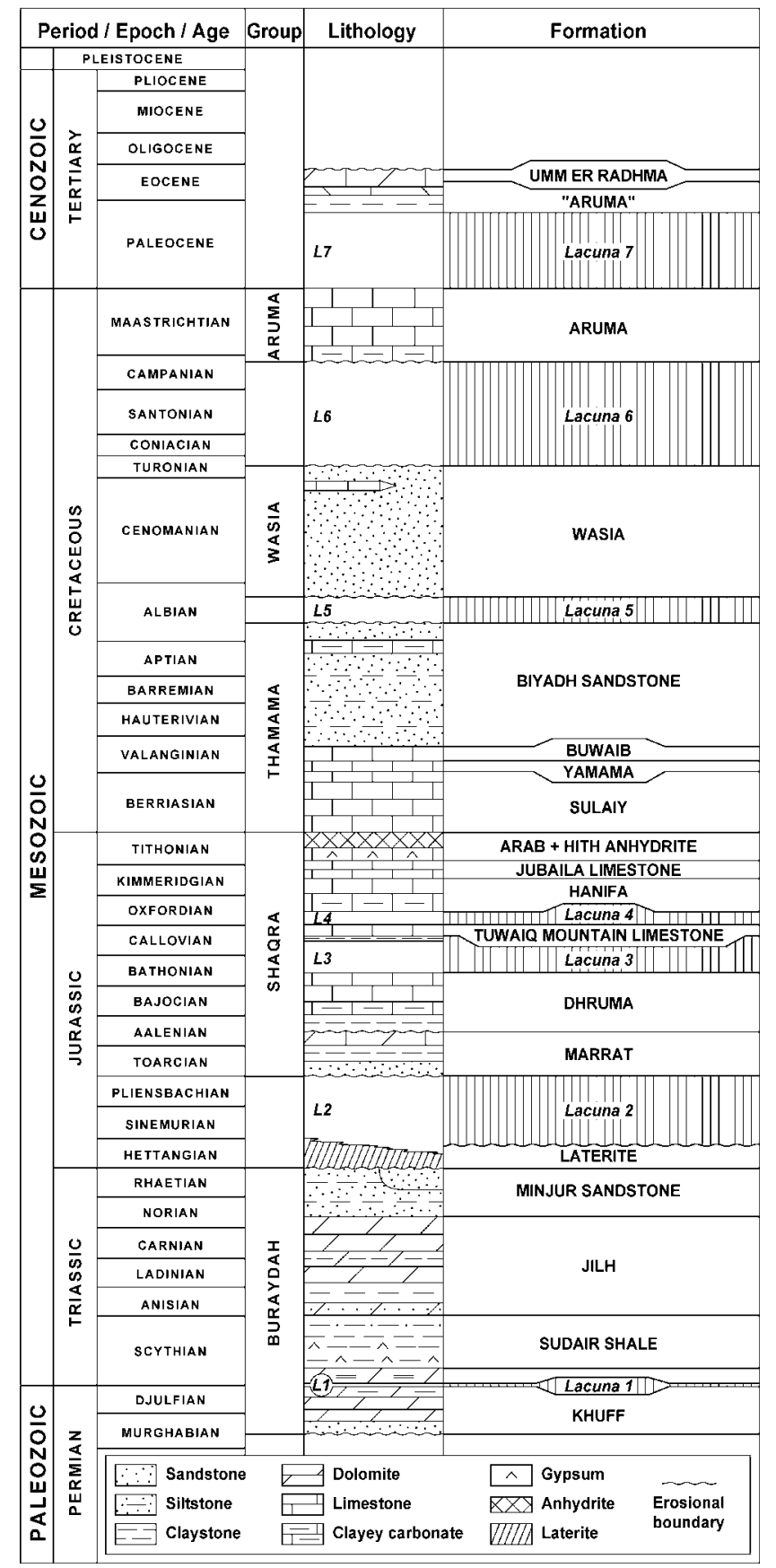

Fig. 34. Late Permian to Eocene lithostratigraphic chart of Central Arabia, slightly modified after Le Nindre et al. (2003).

the offshore Guyana Demerara Plateau. Thick terrigenous or marginal marine formations were deposited (details in Davison, this issue). Post-rift carbonate sequences formed from Toarcian times, in conjunction with moderate thermal subsidence and elevation of sea level. However, the most important characteristics of Liassic times here correspond to the eruption of the Central Atlantic Magmatic Province (CAMP) plume that occurred around $201 \mathrm{Ma}$ (Wilson and Guiraud, 1998; Burke et al., 2003). A widespread tholeiitic magmatic province then briefly developed around the conjugate passive continental margins of Africa and North America, which influenced an area of more than $5000 \mathrm{~km} \mathrm{SW}-\mathrm{NE}$ and $1500 \mathrm{~km} \mathrm{E-W.} \mathrm{Over} \mathrm{West} \mathrm{Africa,}$ mafic dykes, sills, and flows were produced up to southeastern Algeria and central Mali (Fig. 35A).

Around the Horn of Africa, rifting rejuvenated in the Middle or Late Liassic (Fig. 38). Continental terrigenous formations were first deposited, overlain by marginal marine mixed sediments and then carbonates when a marine platform developed in the Toarcian. This platform also extended to Arabia, previously characterized by the development in the earliest Liassic of a large lateritic bauxite belt extending from southern Oman to Israel (Guiraud and Bosworth, 1999).

\subsubsection{Dogger (Middle Jurassic)}

Along the Eastern Mediterranean margin, a set of $\sim \mathrm{E}-$ W trending half-grabens initiated along the Egyptian shelf, and acted as a tensional damping zone for the major $\sim \mathrm{N}-\mathrm{S}$ transform faults that formed the eastward boundary of the oceanic basin (Guiraud and Bosworth, 1999). A carbonate platform developed while the large fluviatile Dakhla Basin provided reduced input of terrigenous sediments (Guiraud et al., 2001). Important hydrocarbon source rocks were deposited along the margin during the Bathonian to Callovian, in both deltaic and marine settings (Keeley et al., 1990; Keeley and Wallis, 1991). A major regression occurred by the end-Callovian (Hirsch, 1990).

Westwards, the subsidence remained active along large parts of the Alpine Maghrebian troughs (Figs. 35B and 36A), infilled by thick marly and turbiditic series. Less subsident areas and platforms registered carbonate sedimentation. Fine terrigenous input, supplied by the large Murzuq Basin and the Oued Mya Basin, begin to spread along the shorelines. In Morocco, this phenomenon strongly increased in the later Dogger (from the end Bathonian?) when local inversion and folding affected the Middle and High Atlas (Piqué et al., 2002; Laville et al., 2004). Syn-tectonic gabroic intrusions and hydrothermal metamorphism also occurred in the High Atlas (Laville et al., 1994). These early Alpine deformations, restricted to narrow domains, probably resulted from local transpression caused by the initiation (or the acceleration) of drifting along the Central Atlantic and associated large strike-slip movements between northwesternmost Africa and Iberia (Fig. 36A).

The Central Atlantic African margin witnessed moderate to weak thermal subsidence, partly related to the Atlantic Ocean opening which probably began in the Dogger (Klitgord and Schouten, 1986; see also discussions in Davison, this issue, and Sahabi et al., 2004). A carbonate platform propagated westward (Ellouz et al., 2003) while shales and breccias were deposited along the slope. The coastal fluviatile basins remained very narrow. The southern limit of the Central Atlantic domain corresponds to the western extension of the Guinean-Nubian lineaments, which were then weakly rejuvenated, also entailing weak subsidence along the southern Mali, intra-continental Nara Trough (Figs. 35B and 36A). 


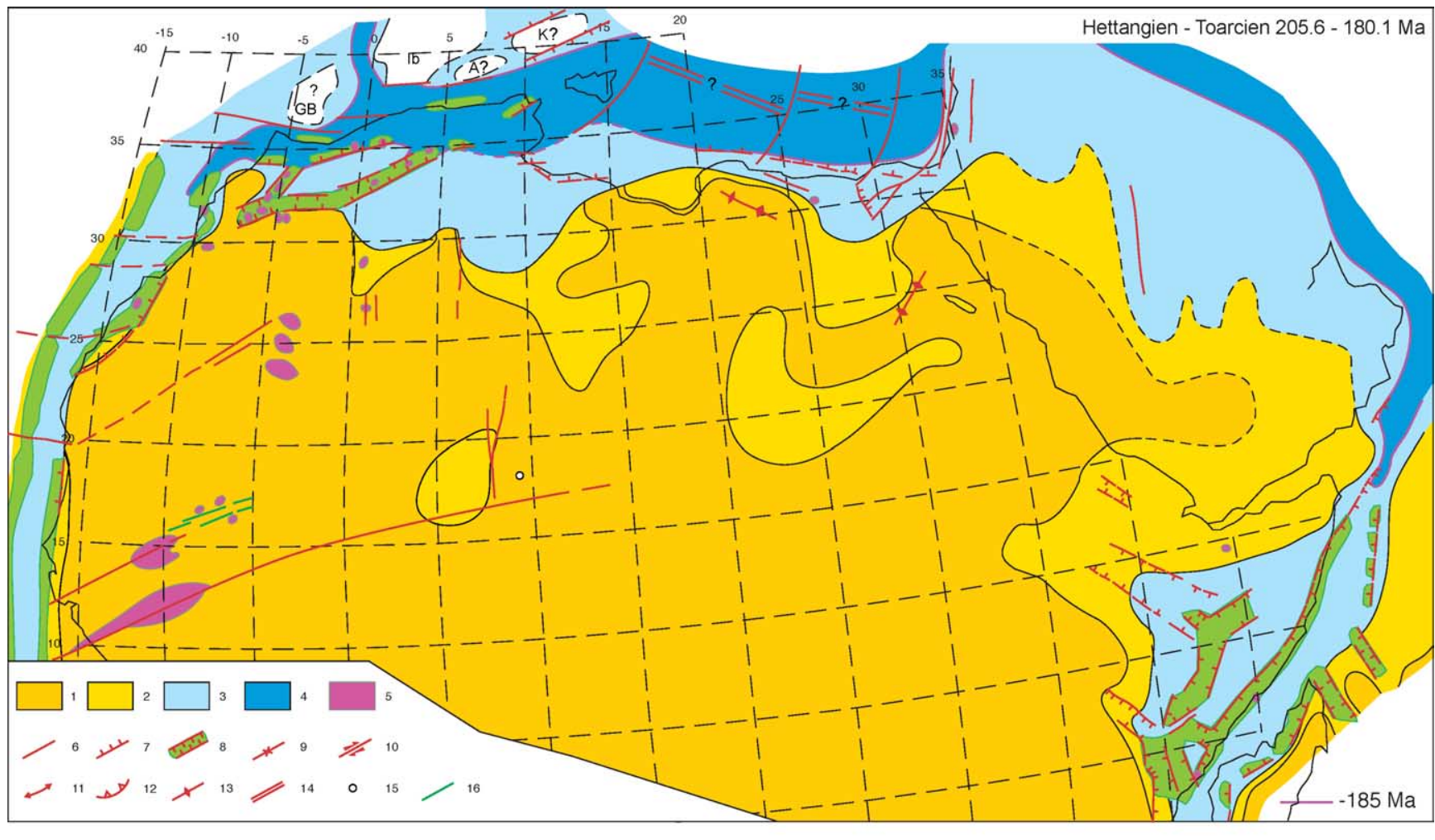

A

Fig. 35A. Hettangian-Toarcian (205.7-180.1 Ma) paleogeological map, modified from Guiraud (2001). Same legend as Fig. 6. A, Alboran; GB, Great Bank; Ib, Iberia; K, Kabylies.

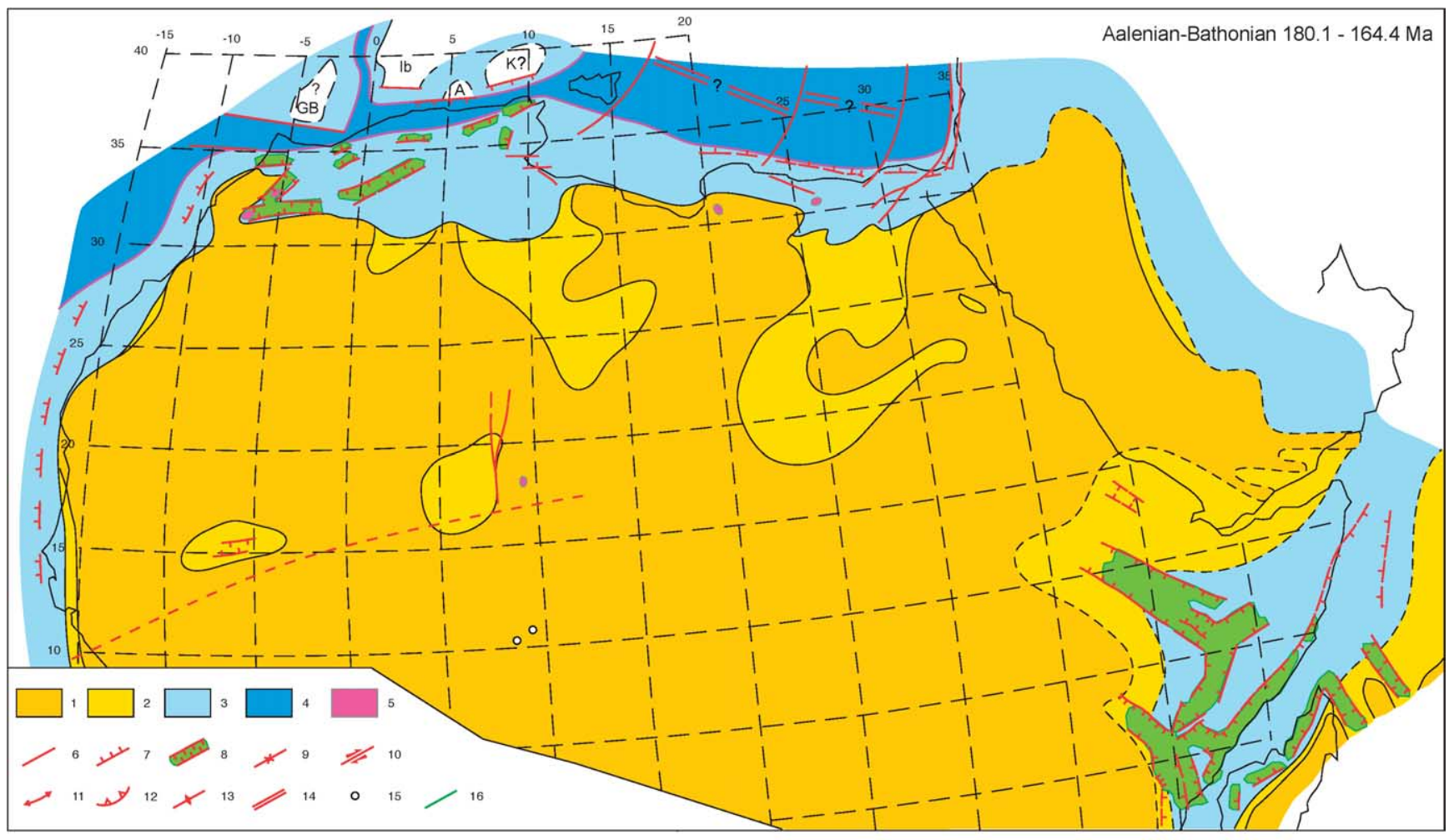

B

Fig. 35B. Aalenian-Bathonian (180-164.4 Ma) paleogeological map, modified from Guiraud (2001). Same legend as Fig. 6. 


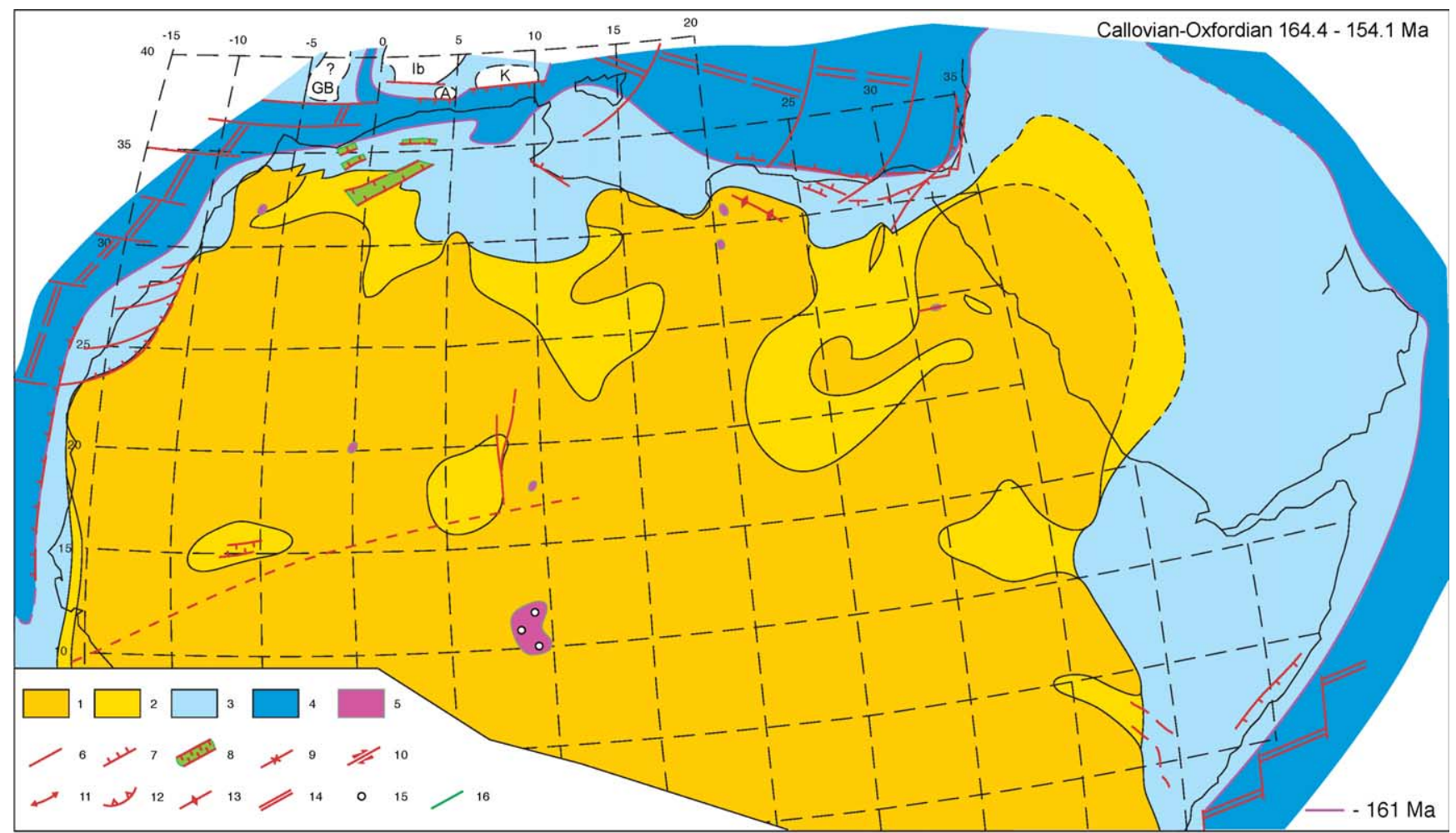

A

Fig. 36A. Callovian-Oxfordian (164.4-154.1 Ma) paleogeological map, modified from Guiraud (2001). Same legend as Fig. 6.

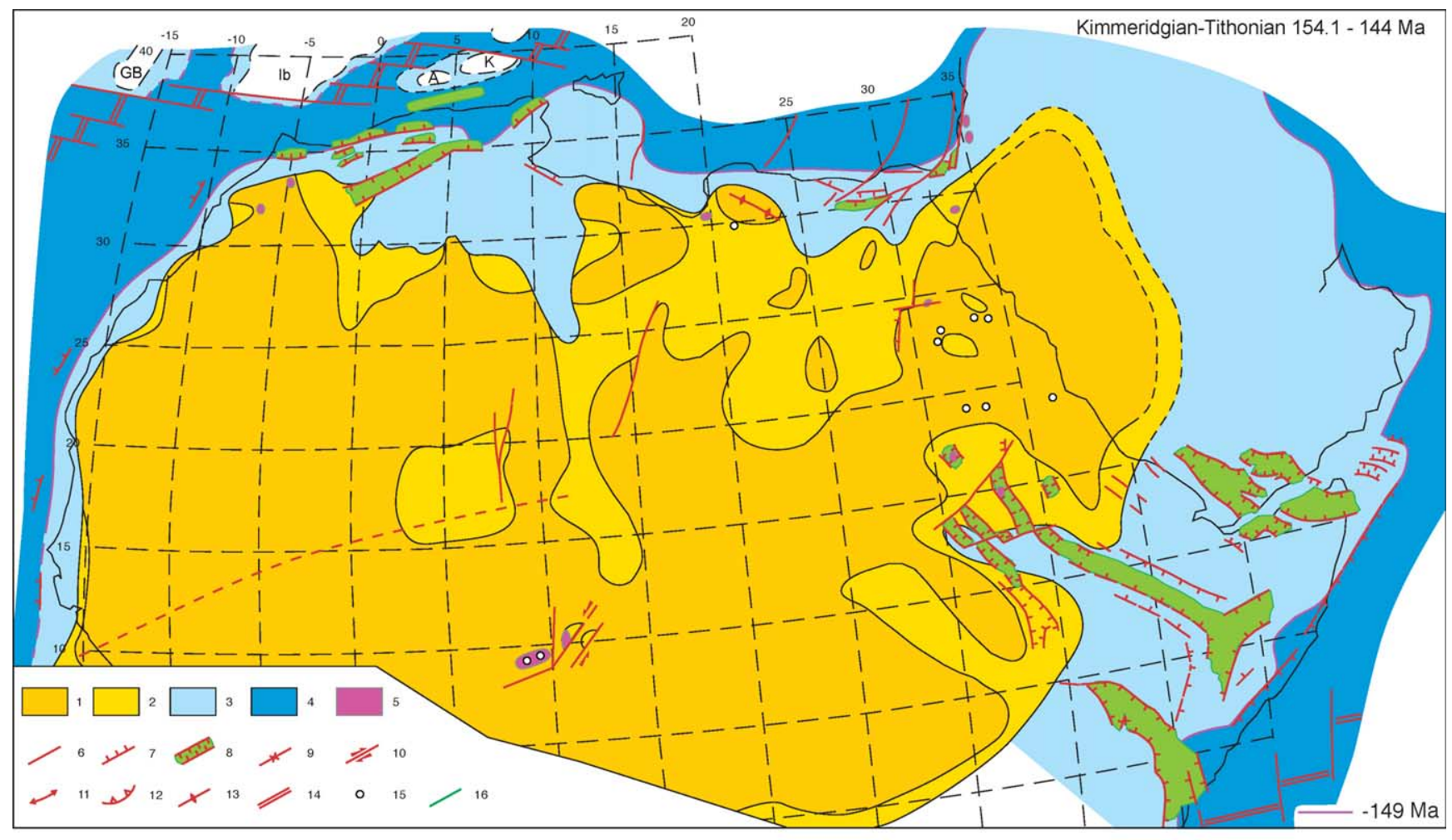

B

Fig. 36B. Kimmeridgian-Early Berriasian (154.1-142 Ma) paleogeological map, modified from Guiraud (2001). Same legend as Fig. 6. 


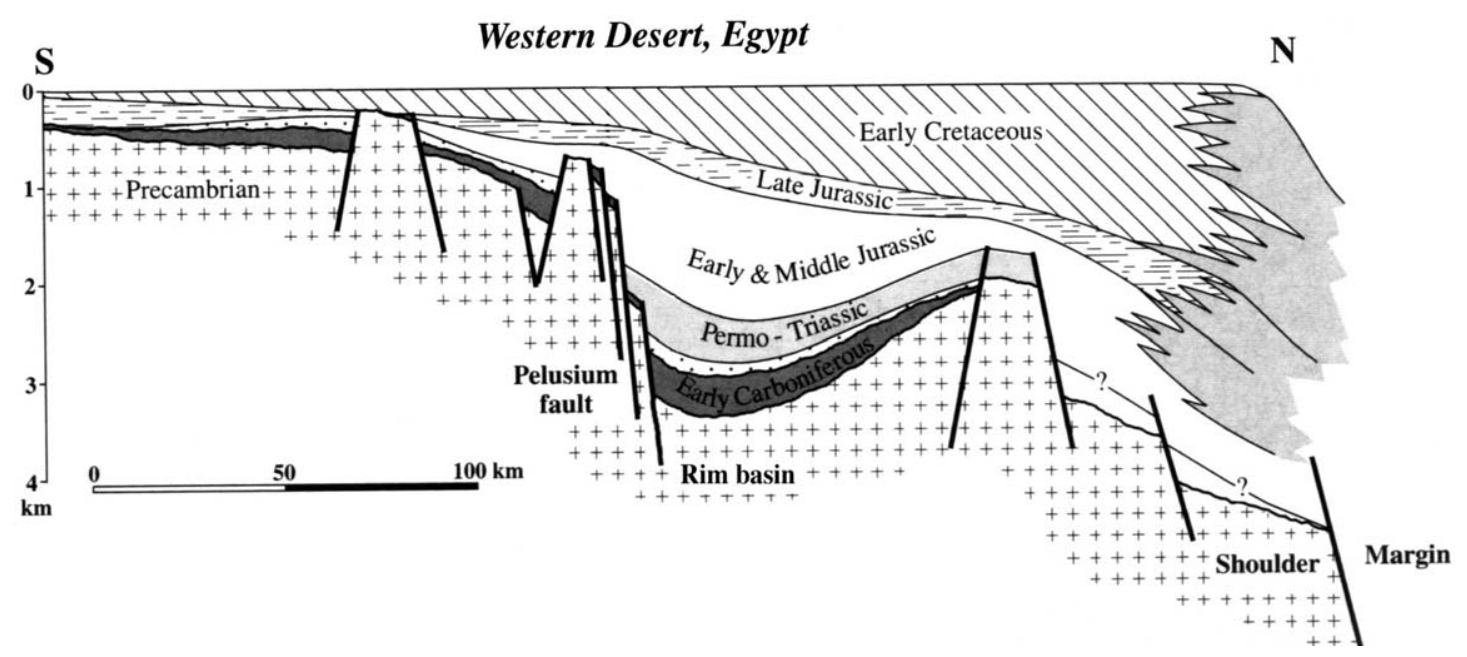

Fig. 37. Early Cretaceous palinspastic cross-section of the Western Desert margin in Egypt, after Stampfli et al. (2001).

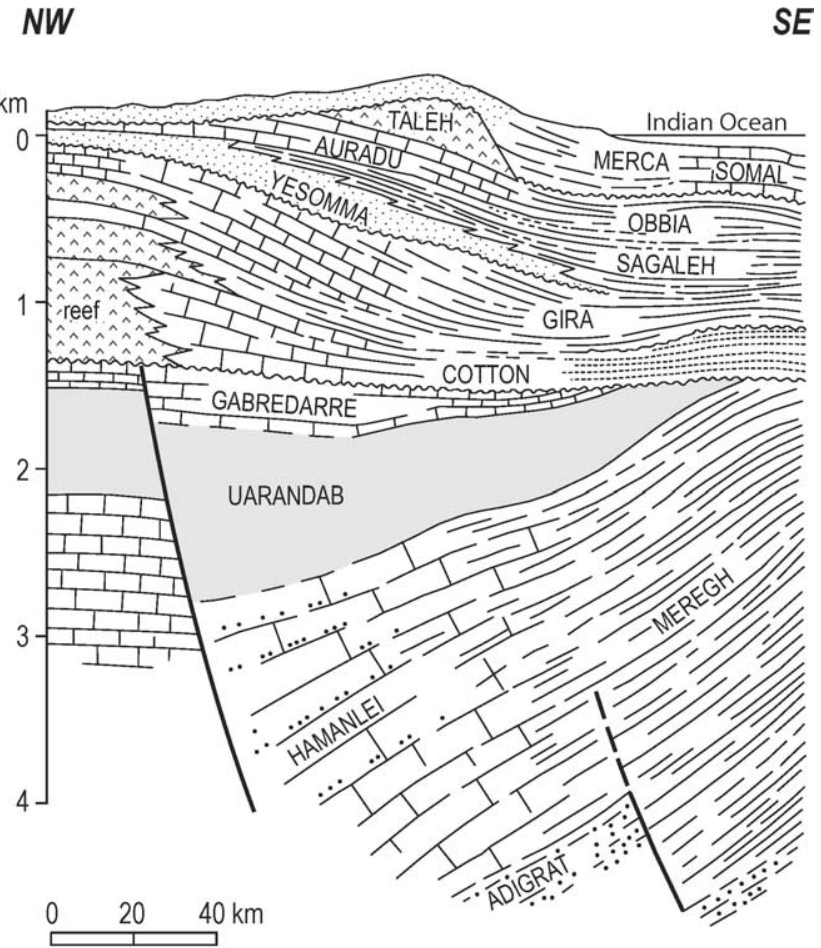

Fig. 38. Schematic geological cross-section of the Mudugh Basin (northeastern Somalia Indian Ocean Margin), slightly modified form Bosellini (1992) . Adigrat $=$ Karoo; Hamanlei, Meregh $=$ Liassic to Dogger; Uarandab, Gabredarre = Late Jurassic; Cotton $=$ Neocomian to Barremian; Gira $=$ Aptian to Santonian; Yesomma, Sagaleh = Campanian to early Paleocene; Auradu, Obbia, Taleh $=$ Paleocene to Middle Eocene; Merca, Somal $=$ Oligocene to Recent.

Around the Horn of Africa, from Aalenian to Bathonian times, thermal subsidence affected the former troughs and marginal marine facies were deposited including thick evaporites (Hamanlei Fm.) along the Ogaden Basin (Mbede, 1987; Pigott et al., 1995) (Fig. 33). A marine transgression initiated in the Callovian, underlined by carbonate platform progradation around the basins and shale deposition along the basin axes.

The Arabian Shield was bordered to the east by a narrow marginal-marine fringe grading into a shallow-marine clastic/carbonate platform and then a shallow-marine carbonate platform (Ziegler, 2001). The latter developed from Callovian times, over-flooding the Yemen area, and joining the Ogaden Gulf (Fig. 36A).

\subsubsection{Late Jurassic and the Cimmerian event}

Along the Eastern Mediterranean margin, block tilting developed in northern Sinai and rifting initiated along the Abu Gharadig Basin of northwestern Egypt (Guiraud and Bosworth, 1999). The Early Kimmeridgian transgression entailed the development of large evaporitic gulfs in southern Egypt (Guiraud et al., 2001), while a carbonate platform prevailed during the Tithonian. Large continental, fluviatile basins remained active (Dakhla, al Kufrah) or initiated (southern Sirt), surrounding some highs such as Uweinat, Bahariya, and southern Cyrenaica (Fig. 36B). Alkali basaltic volcanic activity occurred along the Levant fault zone and southern Sinai (Wilson and Guiraud, 1998).

Westwards, active subsidence prevailed along the large Saharan Atlas, Tunisian Atlas, and south Tellian-Rifian troughs. Deep marine environments developed along the Tellian-Rifian troughs, which deepened in response to transtensional deformations resulting from rapid opening of the Central Atlantic Ocean. Southwards, a narrow slope bordered a large platform extending from westernmost Libya to Algerian-Moroccan confines. Along this platform, shallow marine carbonate deposited northwards, while mixed or terrigenous sediments formed southwards that witness the influence of large fluviatile basins then developing (e.g., the Murzuq-Ténéré and Saoura basins). Along northeastern Morocco, only narrow basins persisted in the eastern High Atlas and northern Middle Atlas domains, fed by terrigenous inputs resulting from the erosion of the then rising central northern Morocco. 
Along the Central Atlantic African margin, the westwards progradation of the carbonate platform carried on. Locally, for example along the Agadir and Essaouira basins, fine or coarse terrigenous sediments prevailed, provided by the uplifts in Morocco.

Within the African continental domain, pre-rift stages initiated along the future Gulf of Guinea (overviews in Guiraud and Bellion, 1995; Basile et al., this issue) and locally, in the Upper Benue area. Half-grabens developed here in the Tithonian times in transtensional stress fields (Fig. 36B), infilled by thick coarse alluvial fans and interbedded alkaline flow basalts (Guiraud, 1993; Maluski et al., 1995). Nearby, the alkaline magmatic province of the Jos Plateau (of the so-called Nigerian "Younger Granites") was intruded (reviewed in Wilson and Guiraud, 1998).

Eastwards, the Horn of Africa troughs extended into Central Sudan (Fig. 36B), mainly along the Blue Nile valley where a narrow rift developed, infilled by fluviatile and marginal marine sediments (including evaporites) interbedded with flow basalts (Wycisk et al., 1990; Bosworth, 1992) (Fig. 39). Northwards, the alkaline Nubian magmatic province rejuvenated (reviewed in Wilson and Guiraud, 1998). Eastwards, marine environments persisted over the Horn of Africa. Thick marl, shale, and limestone formations were deposited in the Ogaden and Lamu-Anza troughs (Mbede, 1987; Pigott et al., 1995). Southwestwards, the Early Kimmeridgian transgression extended over most of the continental Zaire Basin (Cahen, 1983).

Along the southern Arabian Peninsula, NW-SE to E-W trending active rifts developed in Yemen and their extension in northernmost Somalia, infilled by thick shallowmarine shales and shaly carbonates (Fig. 40) covered by evaporites (Ellis et al., 1996). Similar facies were deposited over the eastern Arabian Platform (Ziegler, 2001).

The rejuvenation or initiation of rifting in early Late Jurassic times around the Horn of Africa was associated with the initiation of drifting in the western Indian Ocean Somali Basin (Guiraud and Maurin, 1992). According to Rabinowitz et al. (1983), the opening of the ocean here corresponds to the M25 anomaly that is dated around $156 \mathrm{Ma}$ in the Middle/Late Oxfordian (Gradstein et al., 1995).

Around the Jurassic-Cretaceous transition times, tectonic deformation was registered along most of the basins,

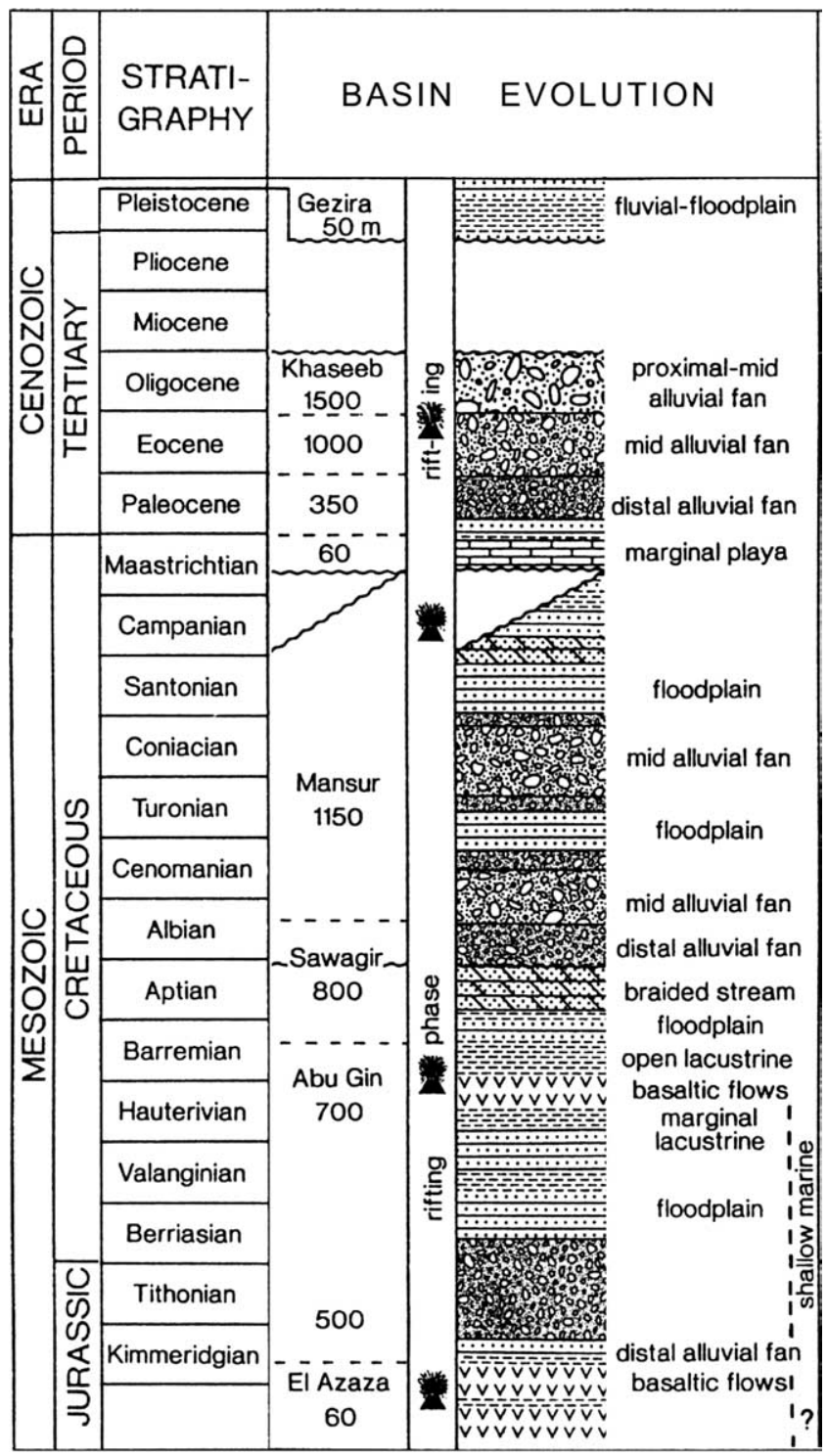

Fig. 39. Lithostratigraphic chart of Late Jurassic to Recent sediments of the Blue Nile rift Basin (east-central Sudan), after Wycisk et al. (1990).

yet they remain of minor importance in Northern and Central Africa. Frequent uplift and block-tilting, sometimes accompanied by slight folding, occurred along the northern Egyptian margin, the Levant (Guiraud, 1998;

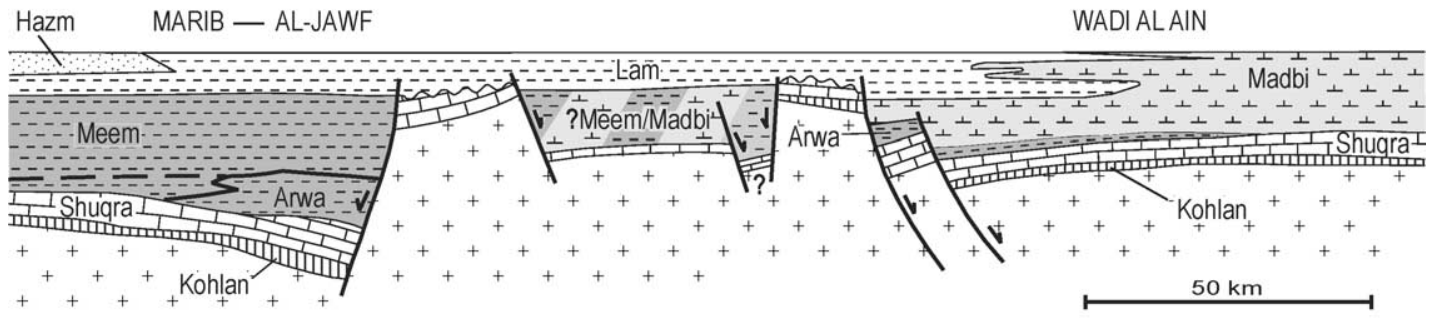

Fig. 40. Schematic cross-section along the Yemen basins illustrating the Late Jurassic rifting, slightly modified after Ellis et al. (1996). 
Le Roy et al., 1998; Coward and Ries, 2003), the northwestern Hoggar margin (Guiraud and Bellion, 1995), the southern Murzuq-Djado Basin (unpubl. works by oil companies), the Upper Benue Trough (Guiraud, 1993) and the Arabian Platform (Ziegler, 2001). These deformations, underlined by hiatuses in the series and unconformities, represent the distant effects of stronger tectonic activity that occurred in southeastern Europe, referred to as the "Cimmerian" or "Berriasian" orogenic event (Nikishin et al., 2001; Stampfli et al., 2001).

\subsection{Cretaceous}

The Cretaceous times correspond to a crucial period for Central and Northern Africa. Active rifting episodes over large domains led to the break-up of Western Gondwana and the opening of the South and Equatorial Atlantic oceans. Magmatism often accompanied rifting. The inversion of many $\sim \mathrm{E}-\mathrm{W}$ trending basins followed in the Late Cretaceous, corresponding to the first stages of the formation of the Alpine Belt. From Aptian times and peaking in the Late Cretaceous, strong warming in the global climate resulted in wide transgressions over large continental subsiding basins.

\subsubsection{Late Berriasian to earliest Aptian (Cretaceous Syn-Rift I Stage)}

From the Late Berriasian to earliest Aptian, continental rifting was very active in Africa-Arabia (Maurin and Guiraud, 1990; Guiraud and Maurin, 1991, 1992). E$\mathrm{W}$ and NW-SE trending rifts initiated or developed over Central Africa s.l. (Figs. 41A, 41B, 42-44) and along the northern African-Arabian Tethyan margin (Fig. 45). The large N-S trending fault zones of the AlgeriaLibya-Niger confines rejuvenated and acted as sinistral strike-slip faults, generating local drag folds or pull-apart basins (Guiraud and Maurin, 1991, 1992; Coward and Ries, 2003). Rifting was also very active along the African-South American confines (Fig. 46A). As a result, the African-Arabian plate tended to separate from the South American plate and to subdivide into three major blocks, namely the Western Block, the Arabian-Nubian Block, and the Austral Block (Guiraud and Maurin, 1992) (Fig. 47A). The Arabian-Nubian Bock then moved northward in response to the opening of the oceanic Somali Basin up to the M0 anomaly ( 120 Ma; Guiraud and Bellion, 1995). Facilitated by tensional stress fields, strong magmatic activity occurred, mainly located in two provinces (Fig. 41A): (1) Nubia and Central/Eastern Sudan, with numerous alkaline anorogenic complexes, alkali dykes, and flow basalts; and (2) the Levant margin (Sinai, Israel, Lebanon, Palmyrides) with predominantly weakly sub-alkaline to alkaline flow basalts (reviewed in Wilson and Guiraud, 1998).

Thick, mainly terrigenous fluviatile-lacustrine formations infilled the rift basins, including up to $4 \mathrm{~km}$ of black shale source rocks in the Salamat Trough of northern
Central Africa Republic-southern Chad (Genik, 1993) (Fig. 42C). Large continental basins developed over Africa that fed terrigenous sedimentation along the surrounding marine platforms. A large delta prevailed over the western Saharan Atlas in Algeria (Busson, 1972; Delfaud, 1974; Lefranc and Guiraud, 1990), which favored the deposition of thick flysch series on the northernmost MoroccanAlgerian-Tunisian Neotethyan margin.

The rifting phase of Stage I was terminated by a regional unconformity ("Austrian" unconformity), especially identified along the Central African Rift System (Fig. 44) and along the Atlantic Ocean margins.

\subsubsection{Early Aptian to late Albian (Cretaceous Syn-Rift II Stage)}

A rapid change in the intra-plate stress-field occurred in the Early Aptian just after the M0 anomaly, around 119 $120 \mathrm{Ma}$. The extension direction, formerly $\mathrm{N} 160^{\circ} \mathrm{E}$ to $\mathrm{N}-$ S, moved to NE-SW (Guiraud and Maurin, 1992) (Figs. 46B and 47B). This resulted in rapid subsidence along the NW-SE trending troughs, e.g., the Ténéré and SudanKenya troughs where up to $3-5 \mathrm{~km}$ of continental sandstone and shale were deposited (Schull, 1988; Bosworth, 1992) (Figs. 42 and 43). Active faulting also affected the Sirt Basin in Libya (Wennekers et al., 1996; Hallett, 2002). Dextral transtension initiated along the Central African Fault Zone (Browne and Fairhead, 1983), activating minor NW-SE trending rifts or pull-apart basins in southern Chad, while rifting continued along some subbasins of the Benue Trough. Strike-slip movements stopped or decreased along the $\mathrm{N}-\mathrm{S}$ trending trans-Saharan fault zones. Taking into account these characteristics, Guiraud and Maurin (1992) concluded that the ArabianNubian Block was then moving northeastwards (Figs. 46B and 47B).

Large continental basins covered Africa. However, two transgressions occurred, around the mid-Aptian and Late Albian (Figs. 26 and 27), resulting in the development of large marine gulfs in southern Egypt and Algeria (Fig. 41B). Carbonate platforms then developed along the African-Arabian Tethyan margin (Masse et al., 1993).

The rifting phase of Stage II was terminated by a regional unconformity, identified both along the Central African Rift System (Genik, 1992), where it often marks the cessation of rifting (Fig. 44), and in numerous domains of the northern African margin (Guiraud et al., 1987; Wennekers et al., 1996) (Fig. 48). There, from Morocco to Libya, gentle folding, faulting and erosion occurred, that could be related with the opening of the Bay of Biscay, which resulted in the rotation of Iberia and minor collision against northwestern Africa (Burke et al., 2003). We also note that the African and South American margins of the Equatorial Atlantic then registered a major tectonic change, resulting in the onset of continental break-up between Africa and South America (Mascle et al., 1988; Benkhelil et al., 1995; Basile et al., this issue). This tectonic event took place during the Late Albian (Guiraud et al., 


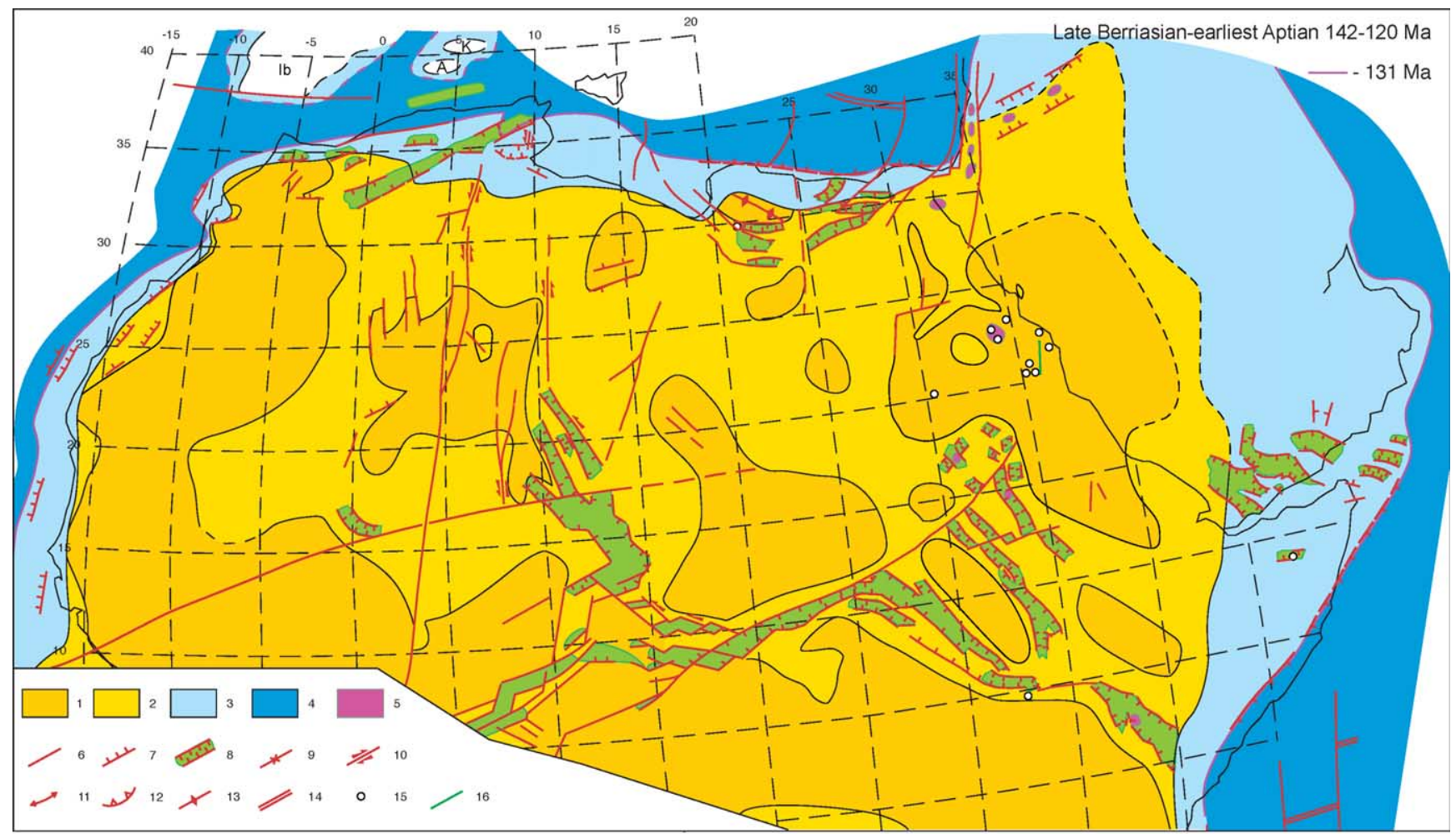

A

Fig. 41A. Late Berriasian-earliest Aptian (142-120 Ma) paleogeological map, modified from Guiraud (2001). Same legend as Fig. 6. A, Alboran; Ib, Iberia; K, Kabylies.

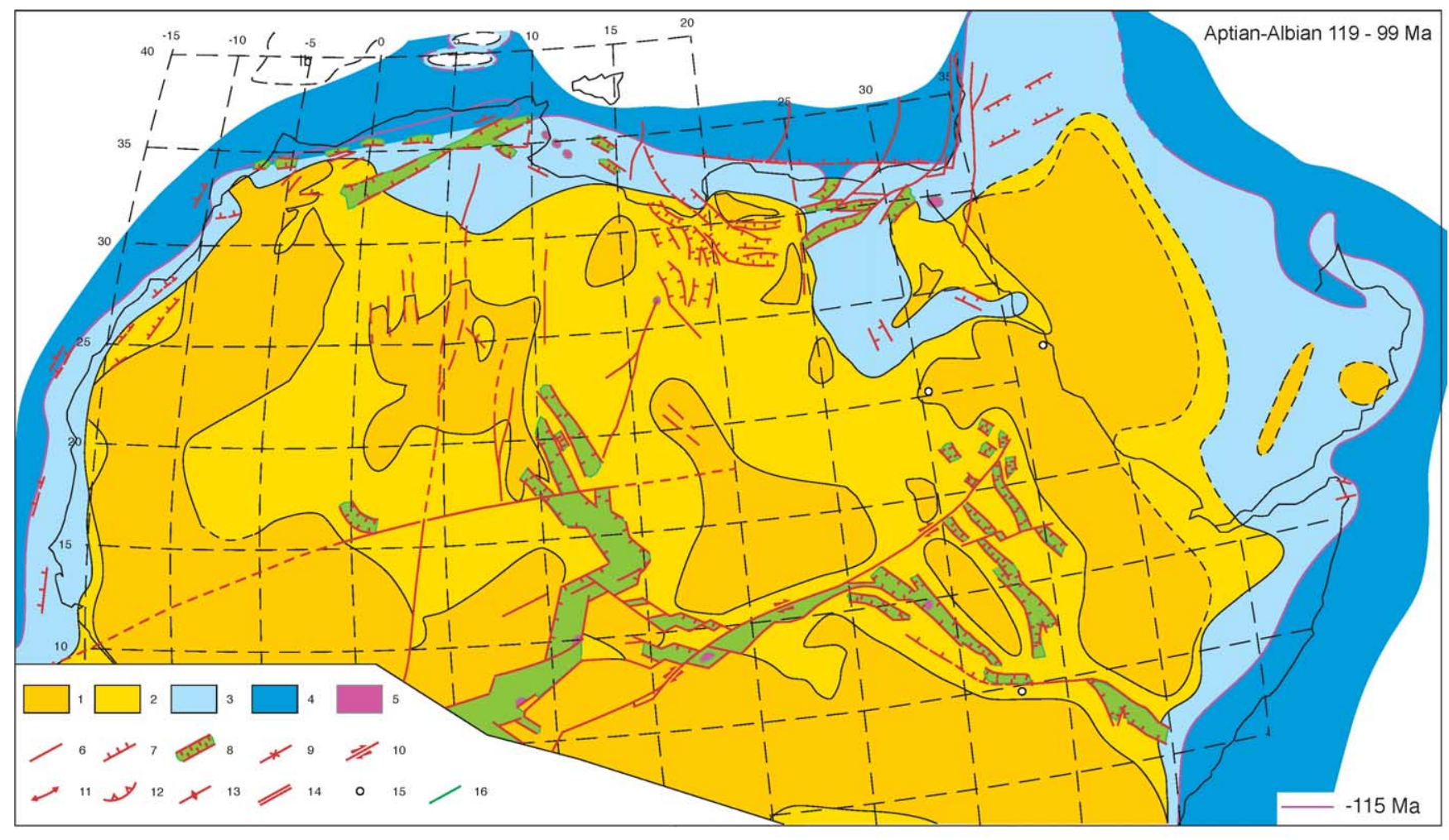

B

Fig. 41B. Aptian-Albian (119-99 Ma) paleogeological map, modified from Guiraud (2001). Same legend as Fig. 6. 


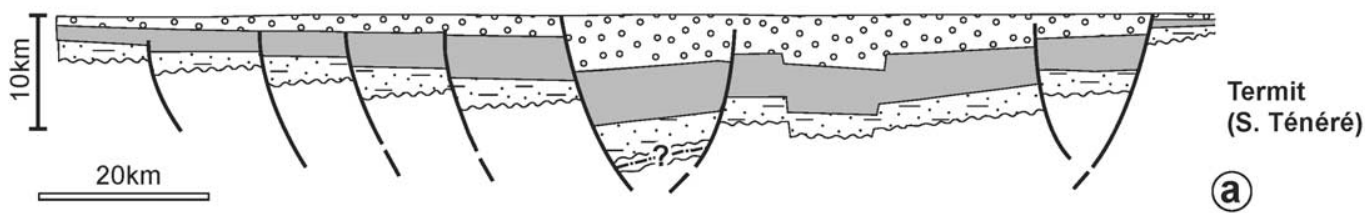

SW

NE

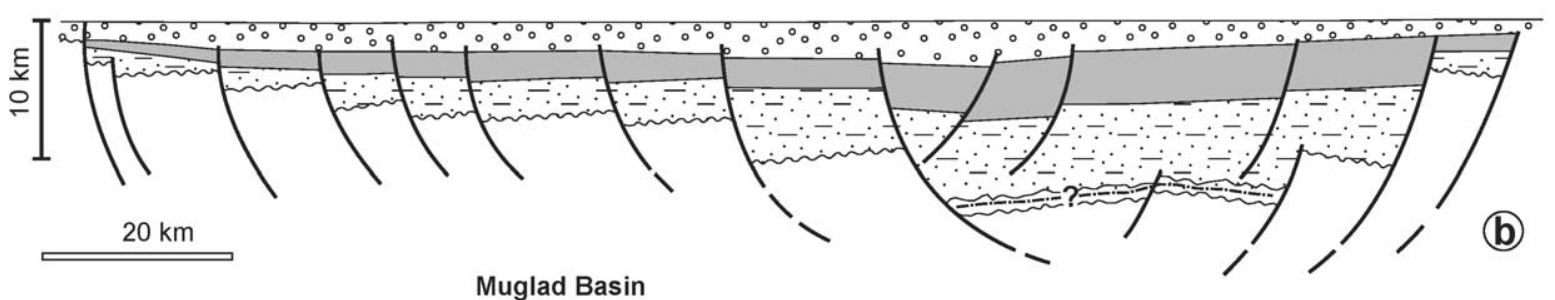

Muglad Basin
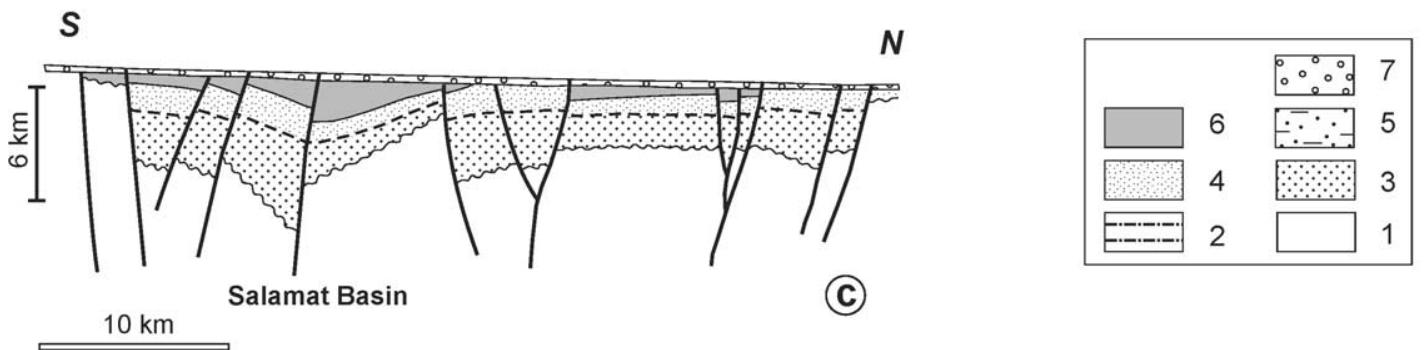

C)

Fig. 42. Schematic geological cross-section of the (a) Termit-Ténéré, (b) Muglad, and (c) Salamat rift basins of Central Africa, slightly modified from Guiraud and Maurin (1992). (1) Proterozoic; (2) Paleozoic to Jurassic; (3) Neocomian to earliest Aptian; (4) Aptian-Albian; (5) Early Cretaceous; (6) Late Cretaceous; (7) Cenozoic.

1987; Saint-Marc and N'Da, 1997; Pletsch et al., 2001) at about 101-102 Ma according to the Gradstein and Ogg (1996) time scale.

\subsubsection{Latest Albian to Middle Santonian (Late Rift to Sag Basin Stage)}

This stage is characterized by a decrease in the tectonic activity and a marine transgression over the Northern and western Central Africa (Figs. 49A and 49B). However, rifting carried on in the Sudan troughs (timing reviewed in Bosworth, 1992), where thick shales, siltstones and sandstones were deposited (Fig. 39 and 43). Locally, and mainly during Cenomanian times, rifting also persisted or initiated in the Doba Basin (southern Chad), the Upper Benue, the Ténéré, and near the eastern Mediterranean margin (Sirt, northern Sinai). For the Central Africa domain, the subsidence is considered to be due to NE-SW directed extension (Bosworth, 1992; McHargue et al., 1992; Guiraud, 1993; Janssen, 1996), sometimes associated with thermal relaxation. Along the northwestern African Maghrebian margin, a very complex system of tilted blocks was active as illustrated by the schematic reconstruction proposed by Wildi (1983) (Fig. 50).

As to the paleogeography, a major change occurred during the Cenomanian as the sea invaded the northern
African platform and then the Niger and Chad intra-continental basins, entering through narrow seaways both from the north (i.e. from the Neotethys) and from the south (i.e. from the South Atlantic via the Benue Trough) (reviewed in Philip et al., 1993a,b). The marine transgression culminated in the Late Cenomanian to Turonian times, associated with warm global climates and highest global Phanerozoic sea levels. Evaporite and then large neritic carbonate platforms developed around the northern and northeastern African-Arabian Tethyan margins (Philip, 2003). In the intra-continental Niger-Chad basins, alternating limestones, marls, shales, siltstones, sandstones and evaporites were deposited (Faure, 1966; Bellion, 1989; Schneider and Wolff, 1992). In the Nubia Province of southern Egypt-northeastern Sudan, deposition of the Nubia sandstone facies was renewed in the Coniacian, when a minor regression occurred, and continued on locally until the early Maastrichtian, before a marine terrigenous shelf extended over parts of northern Sudan (Issawi, 1973; Wycisk, 1991; Guiraud et al., 2001).

Magmatic activity remained minor except in the Tunisian platform, the Levant, Nubia, and along the southern Chad-Benue troughs (Fig. 49A) (reviewed in Wilson and Guiraud, 1998). The alkaline magmatism of the southwestern Benue Trough records the migration of the 


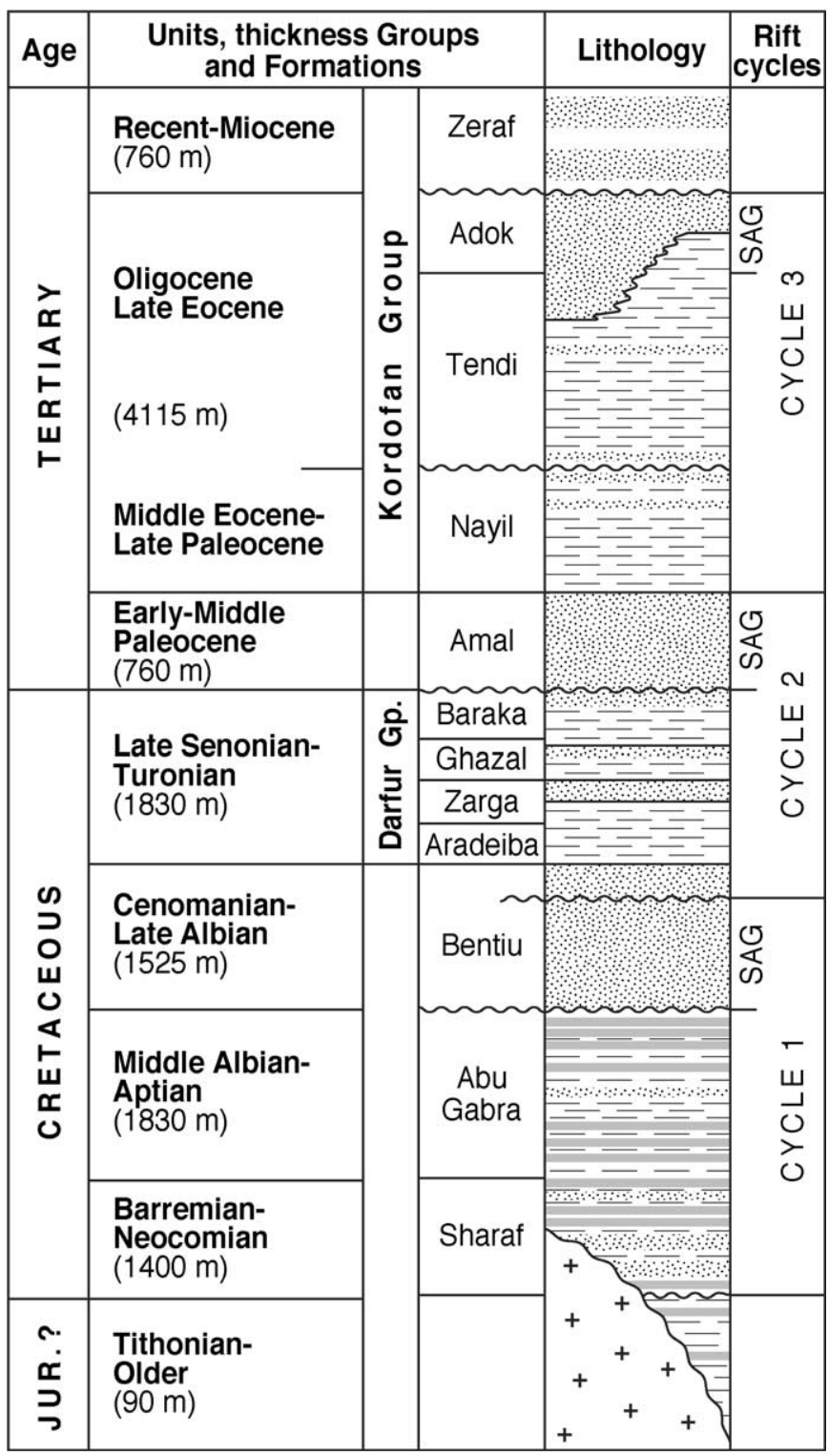

Fig. 43. Schematic stratigraphic column of the Muglad Basin (western Sudan), slightly modified from McHargue et al. (1992) and Mohamed et al. (2002).

African plate over the St. Helena hot spot or mantle plume (Wilson and Guiraud, 1992; Maluski et al., 1995).

\subsubsection{Late Santonian tectonic event}

The presence of frequent hiatuses in the sedimentary series around the Late Santonian times, associated with angular unconformities along the North and Central African fold belts, reflects the occurrence of a tectonic event. The Late Santonian event corresponds to the first general compressional episode registered by the African-Arabian plate during the Alpine Cycle (Guiraud et al., 1987; Guiraud and Bellion, 1995). Guiraud and Bosworth (1997) published a detailed analysis of this event that we summarize hereafter.

Along the northwestern African-plate margin the Alpine Belt was initiated, as demonstrated by the occurrence of isoclinal folding and metamorphism of some Tellian units, local thrusting in the Moroccan High Atlas, and slight folding of large domains of the Saharan Atlas and High Plateaus (Fig. 51). Along the northeastern AfricanArabian margins, folding of the Syrian Arc commenced from Cyrenaica to the Palmyrides (Bosworth et al., 1999) (Fig. 52), while the final stage of the obduction of ophiolites was registered in Oman. Localized uplift occurred within the Sirt Basin, producing islands within an otherwise open to marginal marine setting.

Along Central Africa, $\mathrm{N} 70^{\circ} \mathrm{E}$ to $\mathrm{E}-\mathrm{W}$ trending segments of the Central African Rift System experienced dextral transpressional deformation resulting in large folds (Fig. 53) and positive flower structures, and the inversion of most of the Cretaceous troughs localized between the Lower Benue and westernmost Sudan. Eastwards, along the Kenyan-Somalian confines the ENE-WSW Lugh-Mandera fold belt formed in response to the dextral transpression (Ali Kassim et al., 2002). Between or around these fold belts, local transpressional folds developed along $\sim \mathrm{E}-\mathrm{W}$ relays in the large NW-SE trending Sudan and Ténéré troughs.

In conclusion, this episode can be considered as a platescale event, resulting in inversion or folding of most of the $\mathrm{E}-\mathrm{W}$ to ENE-WSW trending basins in response to $\sim \mathrm{N} 160^{\circ} \mathrm{E}$ oriented shortening. Also registered in Eurasia (Guiraud and Bosworth, 1997; Ziegler et al., 2001), it resulted from a change in plate motions around $84 \mathrm{Ma}$ (Fig. 54). The African-Arabian plate then strongly rotated in an anticlockwise direction and this resulted in the onset of the collision with the Eurasian plate (Olivet et al., 1984). These events are linked to changes in the opening direction and rates of the Central Atlantic, South Atlantic and initiating North Atlantic oceans, and resulting flow-line geometries (Binks and Fairhead, 1992; Guiraud et al., 1992; Fairhead et al., 2003). More generally, the Santonian event corresponds to a global event, underlined by its synchronism with the end of the "Cretaceous Normal Magnetic Quiet Zone" (Guiraud and Bosworth, 1997; Sager and Koppers, 2000).

\subsubsection{Late Senonian and end Cretaceous tectonic event}

The Late Santonian tectonic event resulted in major changes in the topography of North and Central Africa, with the development of narrow fold-induced relief and the uplift of large areas. The epicontinental seas regressed from the eastern Niger-western Chad-Benue domains. However, a new stage of global high sea level in the Campanian-Maastrichtian resulted in the development of a shallow marine platform over the eastern Taoudenni Basin and the Iullemmeden Basin of western Niger (Fig. 49B).

The convergence speed of the African-Arabian and Eurasian plates decreased in the earliest Campanian times (Fidalgo Gonzáles, 2001). However, tectonic instability carried on, as illustrated by both active structures and sedimentology (Guiraud and Bosworth, 1999). Rifting rejuvenated along the NW-SE trending troughs in Sudan-Kenya 


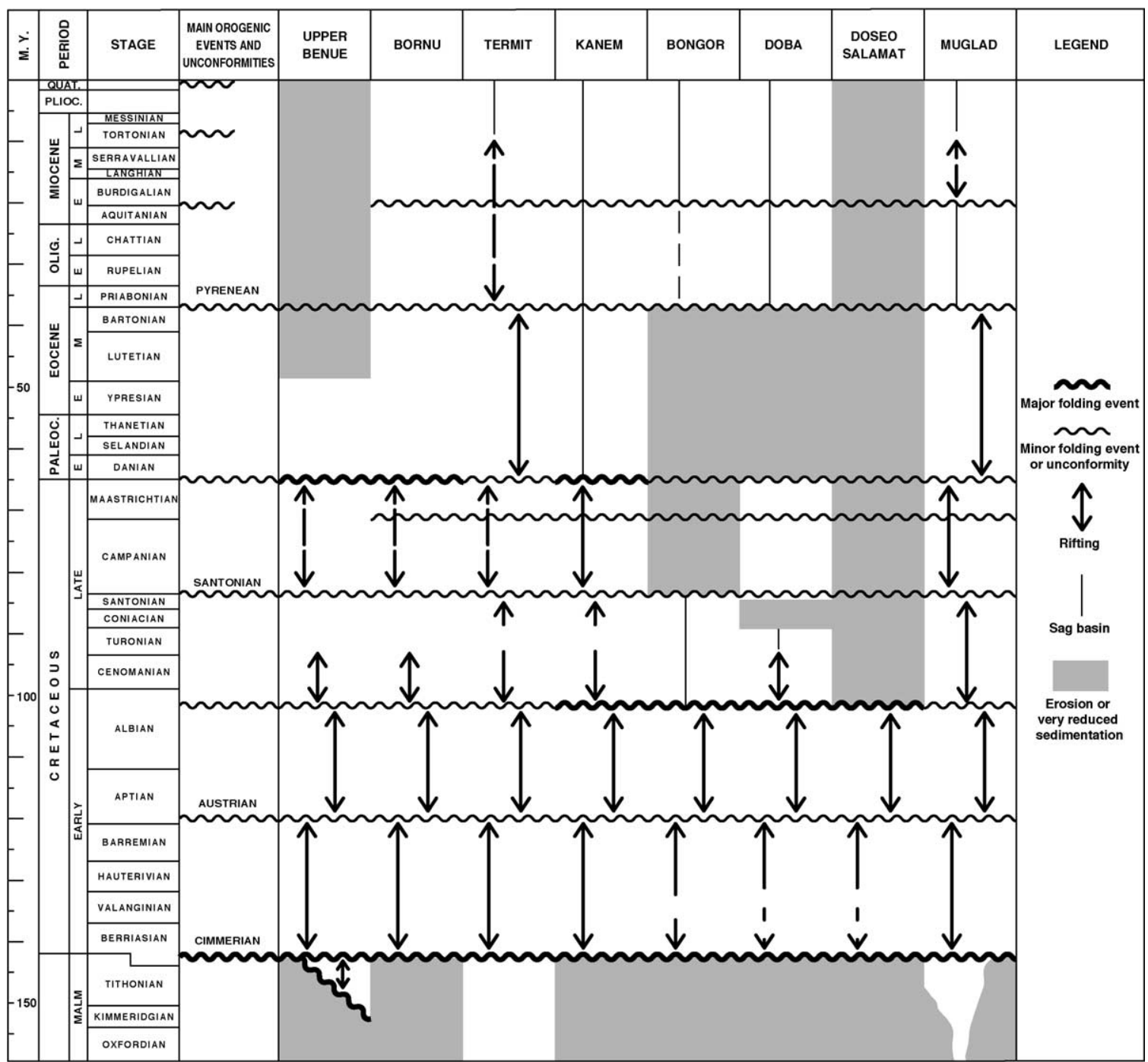

Fig. 44. Tectonic correlation chart of the Late Jurassic to Recent basins of the West and Central African Rift System.

NNW

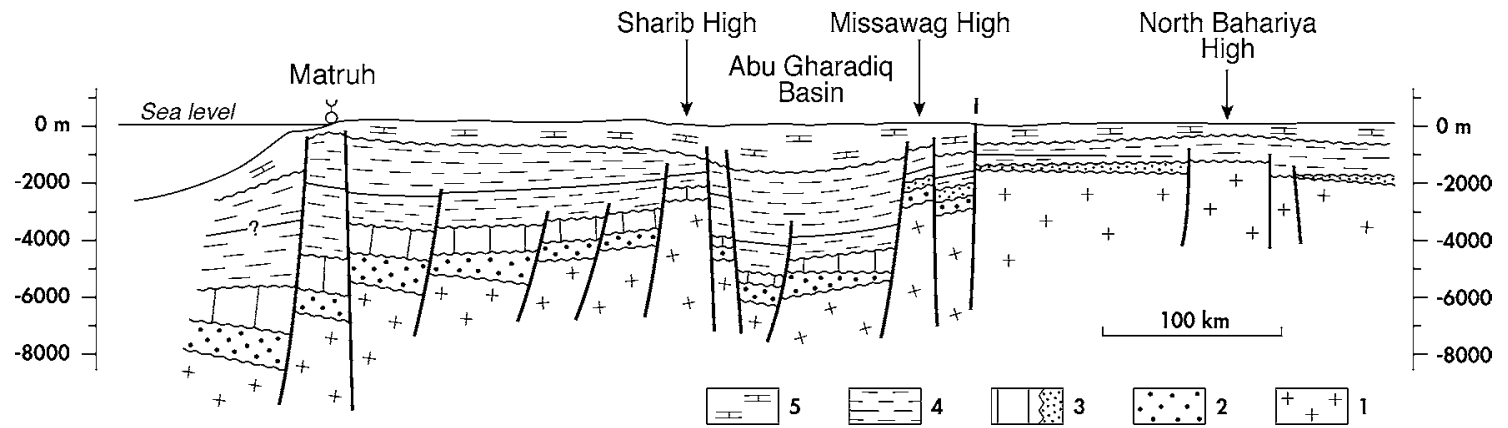

Fig. 45. Schematic geological cross-section along northwestern Egypt, after Guiraud and Bosworth (1999). Vertical exaggeration $\times 13$. (1) Pan-African basement; (2) Paleozoic; (3) Jurassic, mainly marine (vertical bars) or mainly continental (stippled), possibly including some Triassic near the present-day shoreline; (4) Cretaceous, the black line corresponds to the top Alamein dolomite ( top Aptian); (5) Cenozoic.

(Fig. 55) and eastern Niger, and initiated or accelerated along most of the Sirt sub-basins (Fig. 56). Approximately
E-W oriented subsident basins developed along the northern African Tethyan margin, sometimes as pull-apart 


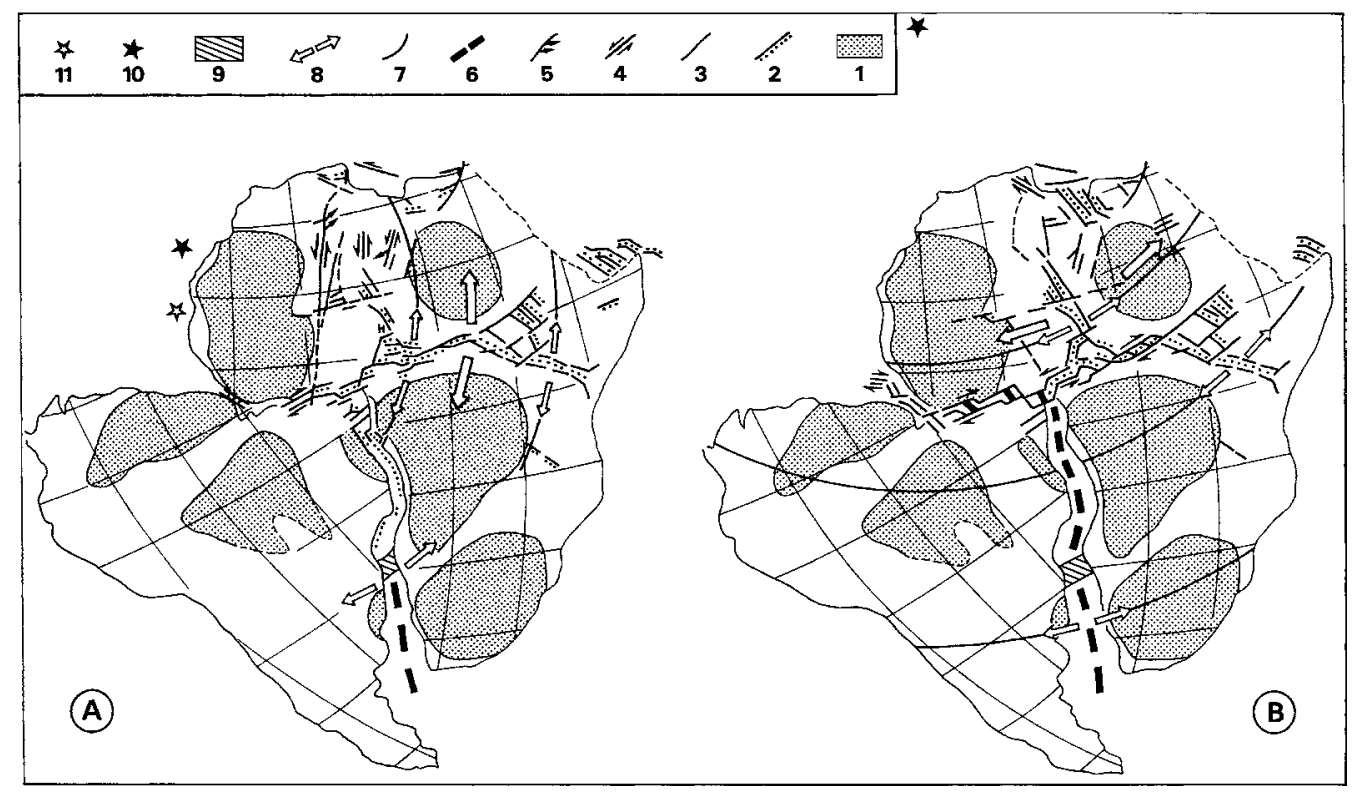

Fig. 46. Two stage development of African rifts during Early Cretaceous: (A) Barremian, (B) Albian. Slightly modified from Guiraud and Maurin (1992). (1) Craton; (2) rift; (3) active fault; (4) major strike-slip fault; (5) compressional zone at the end of wrench fault; (6) oceanic crust; (7) flow line; (8) extension direction; (9) Walvis-Rio Grande Ridge; (10) pole of rotation, after Fairhead (1988) for Fig. 46A and Klitgord and Schouten (1986) for Fig. 46B; (11) pole of rotation proposed by Guiraud and Maurin (1992).

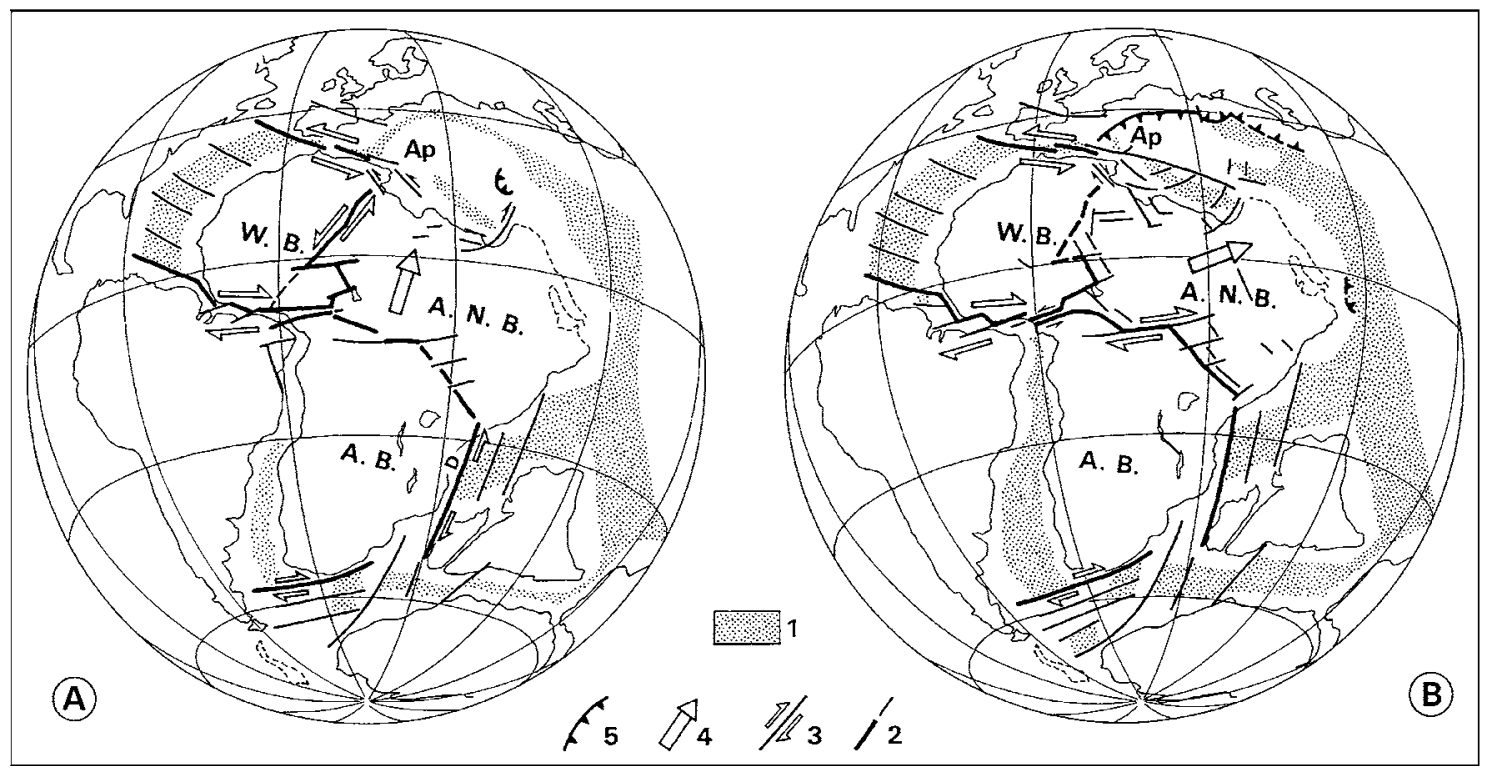

Fig. 47. Subdivision of Africa into major blocks during Early Cretaceous. (A) Late Barremian (122 Ma). (B) Early Albian (110 Ma). After Guiraud and Maurin (1992). A.B., Austral block; A.N.B., Arabian-Nubian block; W.B., Western block; Ap, Apulian plate; D, Davie Ridge. (1) Oceanic crust; (2) fault or strike-slip fault; thick lines indicate block boundaries; (3) major strike-slip fault, or transfer fault, with relative motion; (4) relative motion of the Arabian-Nubian block during the Early Cretaceous; (5) thrust.

deepening in response to dextral transtension, or as flexural basins in the vicinity of the Benue-Bornu fold belt. For most of these basins, the thickness of the Late Senonian deposits was between 2 and $5 \mathrm{~km}$. The more frequent sediments were clastics, marl, or chalk, exhibiting frequent slump bodies. Flysch, including breccias, were deposited along the northernmost margins of Algeria and Arabia. Along Central Africa and southern Western Africa, large exposed high continental domains underwent tropical weathering and laterite bauxites development, as the monsoon regimes initiated in conjunction with the opening of the Equatorial Atlantic and the then favorable paleolatitudes.

The development of a regional tensional regime was probably responsible for the occurrence of stronger magmatic activity, which was described by Guiraud and 


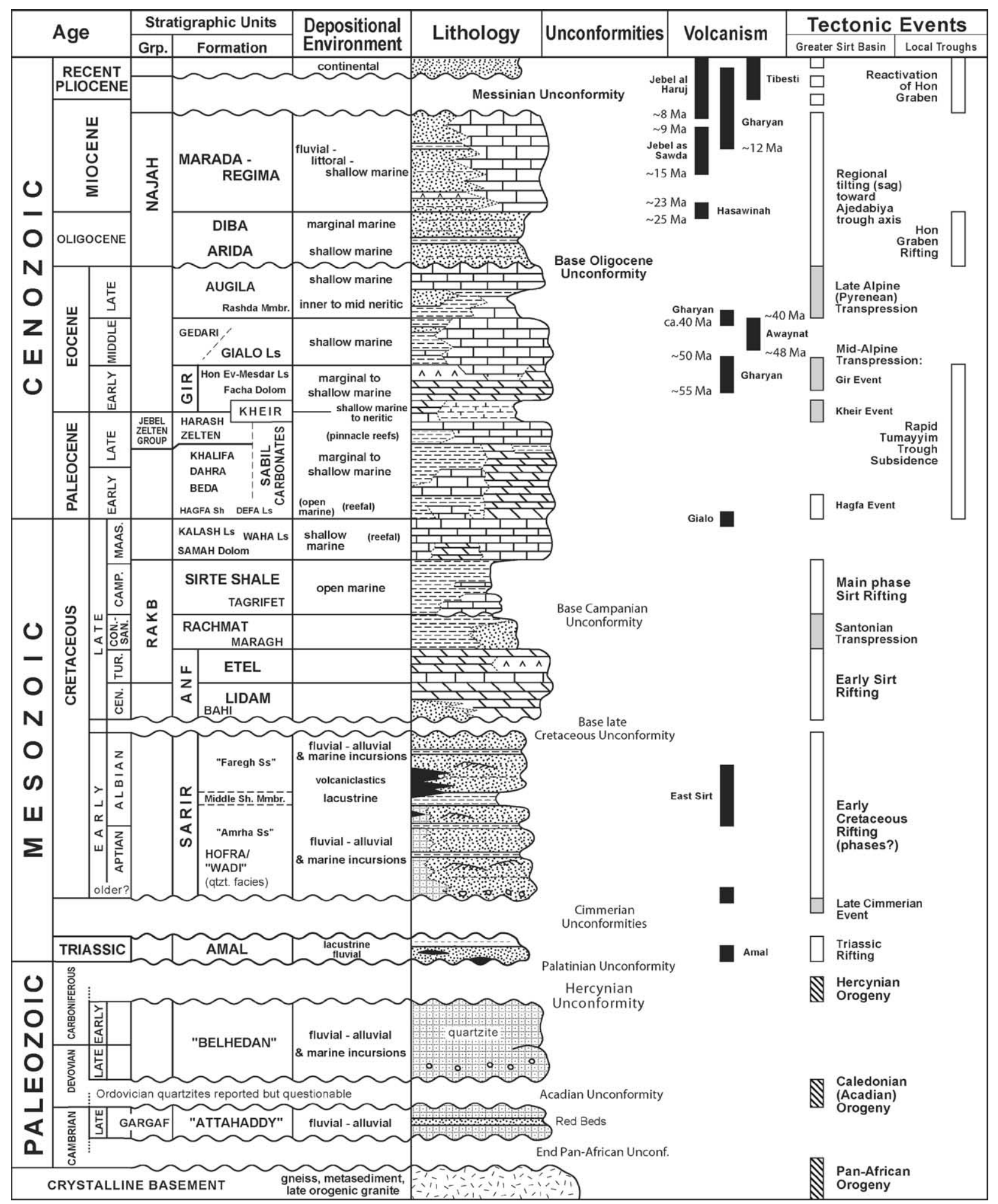

Fig. 48. Phanerozoic tectono-stratigraphy of the Sirt Basin, Libya. Vertical bars: black, volcanism, with radiometric ages where known; white, rifting or post-rift sag basins; grey, predominantly transpressional events; diagonal ruling, predominantly compressional events. Names in "quotes" are informal.

Bosworth (1997) and Wilson and Guiraud (1998). We only mention the location of the main provinces (Fig. 49B): (1) around the western to eastern Mediterranean confines, (2) along the West African Atlantic margin, (3) along the Cameroon Line, (4) in Nubia in Sudan and southern Egypt, and (5) along the East African margin.
Around the Maastrichtian-Paleocene boundary, a new compressional episode affected the northern AfricanArabian Fold Belt (Guiraud and Bosworth, 1997) (Fig. 51). The former Late Santonian folds were accentuated during this "End Cretaceous event." Noticeable dextral transpression occurred along the southern Egypt 


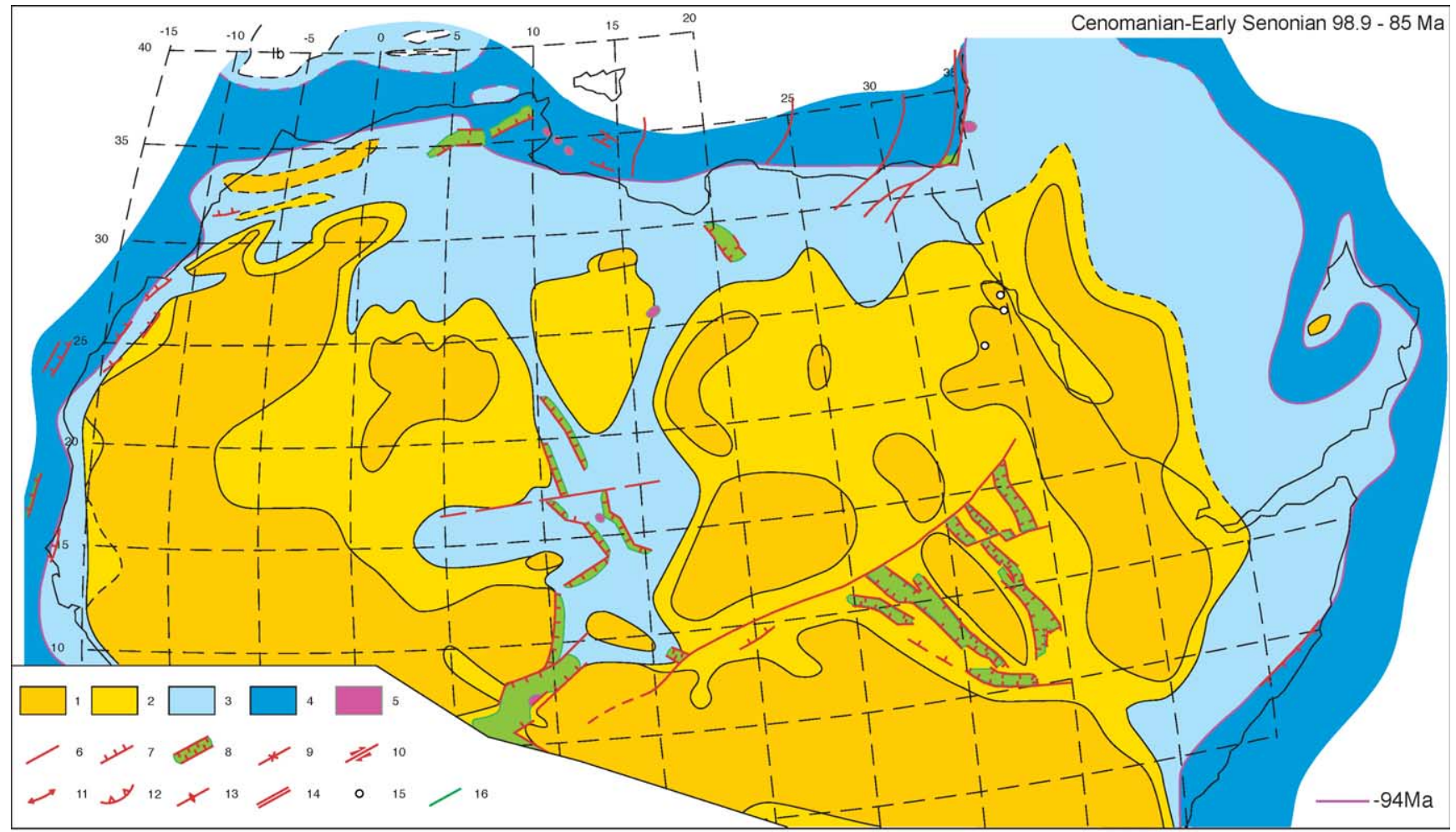

A

Fig. 49A. Latest Albian-Early Senonian (98.9-85 Ma) paleogeological map, modified from Guiraud (2001). Same as legend as Fig. 6.

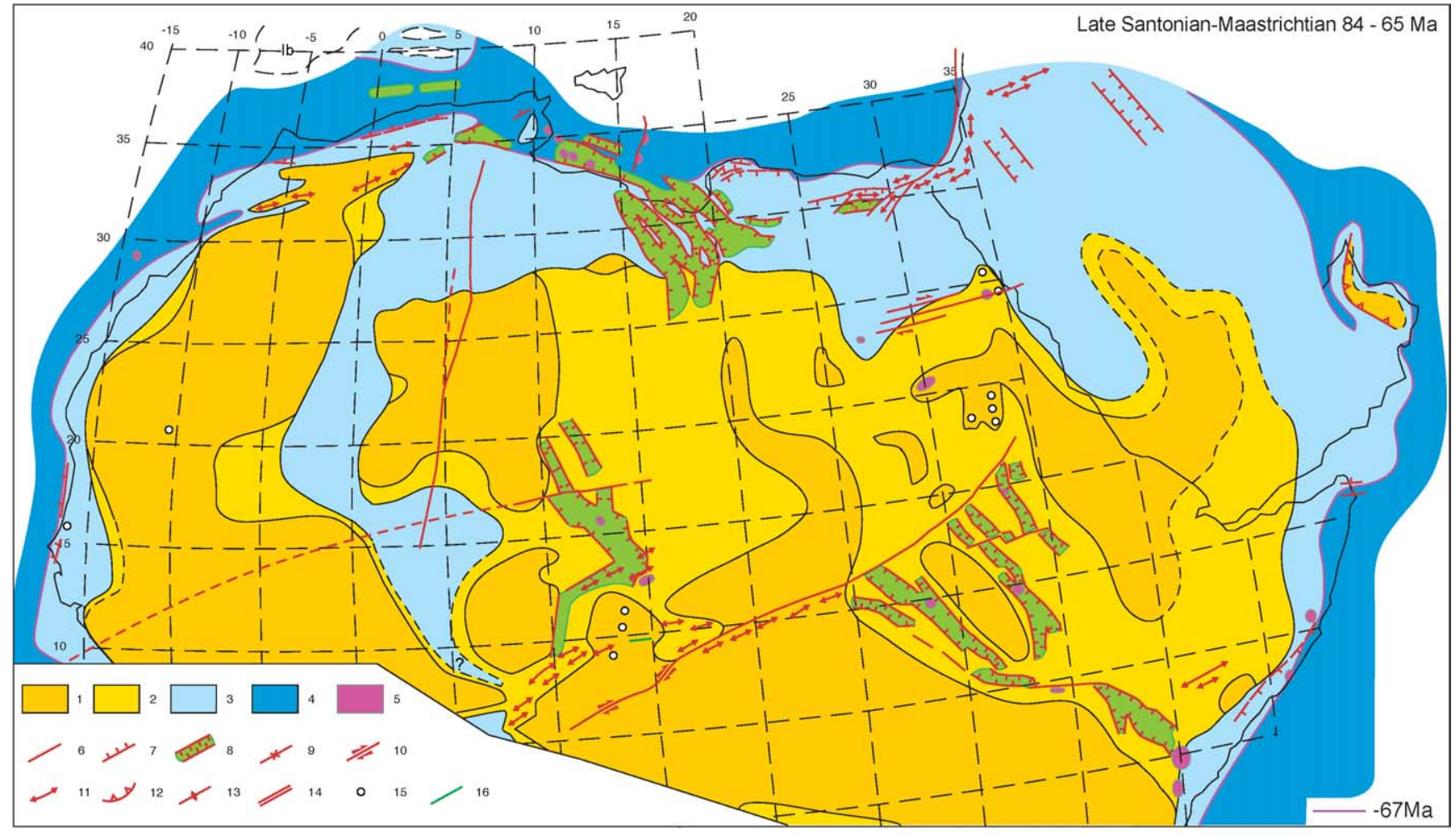

B

Fig. 49B. Late Santonian-Maastrichtian (84-65 Ma) paleogeological map, modified from Guiraud (2001). Same legend as Fig. 6. 


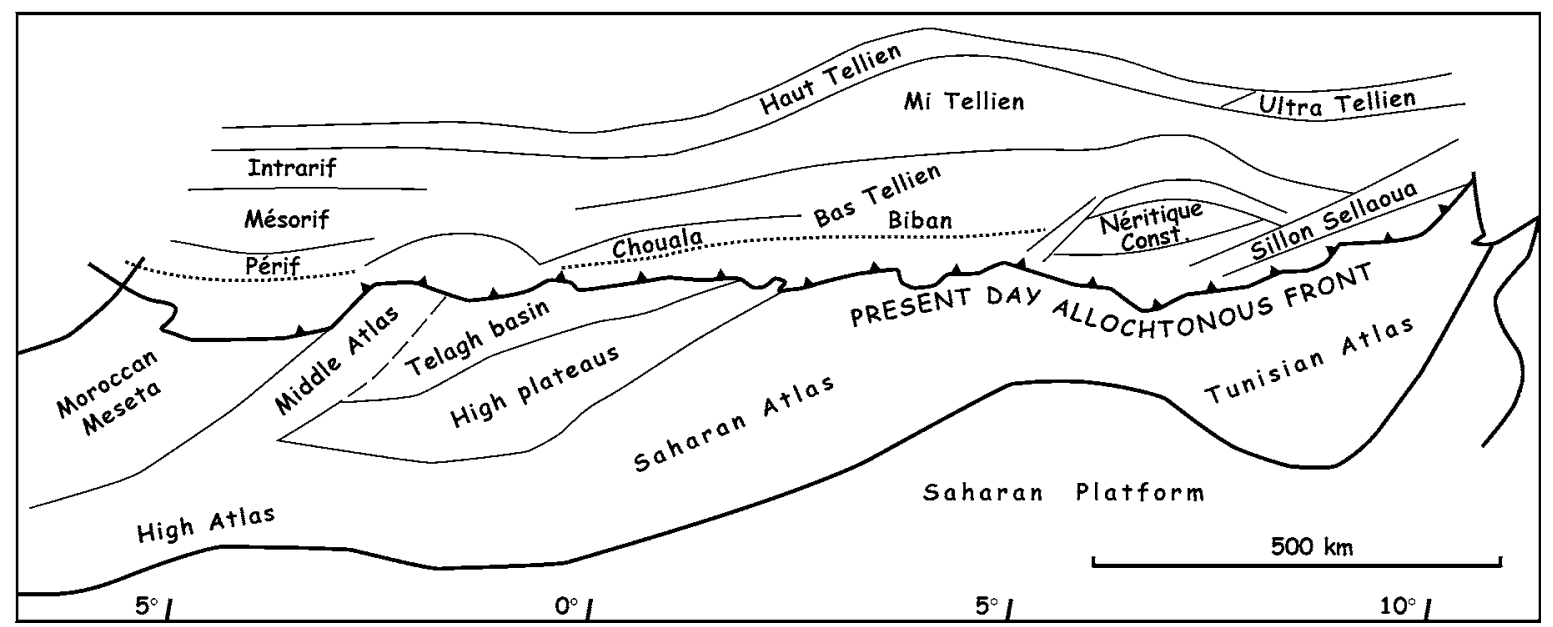

Fig. 50. Schematic palinspastic map of the Maghrebian Alpine margin in the early Late Cretaceous, slightly modified from Wildi (1983).

E-W trending Aswan fault swarm. In a few areas, for example northeastern Algeria (Aris et al., 1998) or the Palmyrides (Salel and Séguret, 1994), the compression initiated a little sooner during the Late Maastrichtian. On a plate scale, the shortening direction was NNW-SSE oriented, i.e. very similar to the Late Santonian direction (Guiraud and Bosworth, 1997). Volcanism was locally important, as for example in the offshore Pelagian Basin and possibly in the eastern Sirt Basin.

\section{Cenozoic evolution}

\subsection{Paleocene to Middle Eocene}

A large transgression developed in the Paleocene and shallow marine shale or limestone were often unconformably overlaid on older formations. An epicontinental sea briefly surrounded the Hoggar Massif during the Late Paleocene (Fig. 57A), allowing the deposition of thick organic rich shales in the still active Ténéré trough (Fig. 26). Narrow gulfs developed up to northern Sudan and along the Red Sea Province (Guiraud et al., 2001). Rifting continued in the continental troughs of Sudan and Kenya, infilled by sandstones and shales. However, several $\sim \mathrm{E}-\mathrm{W}$ trending ridges were uplifted during the Late Paleocene along the northern African Tethyan margin, while folding developed in Israel and thrusting carried on in the Palmyrides (reviewed in Guiraud and Bosworth, 1999). These deformations may be manifestations of a major event described in Western Europe as the "Laramide event" (Ziegler, 1990).

During the Early and Middle Eocene, shorelines slightly regressed (Fig. 57B). A carbonate platform covered most of the marine domains, but the southern and western Sirt gulf then exhibited intercalated evaporitic sedimentation (Wennekers et al., 1996). Mixed platforms tended to develop locally in the late Lutetian-Bartonian. Gentle tectonic activity persisted, mainly characterized by subsidence of the Sirt, northwestern Egypt, Kenya-Sudan, and south
Ténéré troughs, and local folding and thrusting in Israel and the Palmyrides.

During these times, magmatic activity was reduced, but persisted in the Nubia Province, on the Pelagian platform, in the then initiating Ethiopian Province, along the Horn of Africa margin, and along the Cameroon Line (reviewed in Wilson and Guiraud, 1998) (Figs. 57A and 57B).

\subsection{Early Late Eocene ("Pyrenean-Atlasic") compressive event}

By the Bartonian-Priabonian transition times ( $37 \mathrm{Ma})$ a brief, major compressional event occurred (Fig. 58). Guiraud (1973, 1990) and Guiraud et al. (1987) established the importance and precise dating of this event from studies on the northwestern African Maghrebian Alpine Belt. The Saharan Atlas-Aurès domain then registered major folding (Guiraud, 1975; Piqué et al., 2002) (Fig. 59), while the internal Rifian-Tellian domain (Alboran-Kabylies) underwent thrusting and slight metamorphism probably related to the initiation of the subduction of the Maghrebian Tethys underneath the Iberian Balearic margin (Frizon de Lamotte et al., 2000) (Figs. 60 and 61). Eastwards, along the Eastern Mediterranean-Arabian margin, folding and local thrusting also developed along the Syrian Arc s.l., from Cyrenaica to the Palmyrides (Guiraud and Bosworth, 1999).

In the intra-plate domain, many fault zones were rejuvenated as strike-slip faults with associated drag folds (Guiraud and Bosworth, 1997). Among these are the N-S trending, sinistral trans-Saharan fault zones crosscutting the Hoggar Massif and surrounds, and the E-W trending, dextral Guinean-Nubian lineaments. The west Hoggar Pan-African suture also was reactivated as a bundle of reverse faults (Bellion and Guiraud, 1988). Minor angular unconformities associated with this event can be observed along most of the sedimentary basins, e.g., the Oued Mya (Fig. 25) or the Iullemmeden (Fig. 62) basins. Within the Horn of Africa, intense folding and strike-slip faulting 


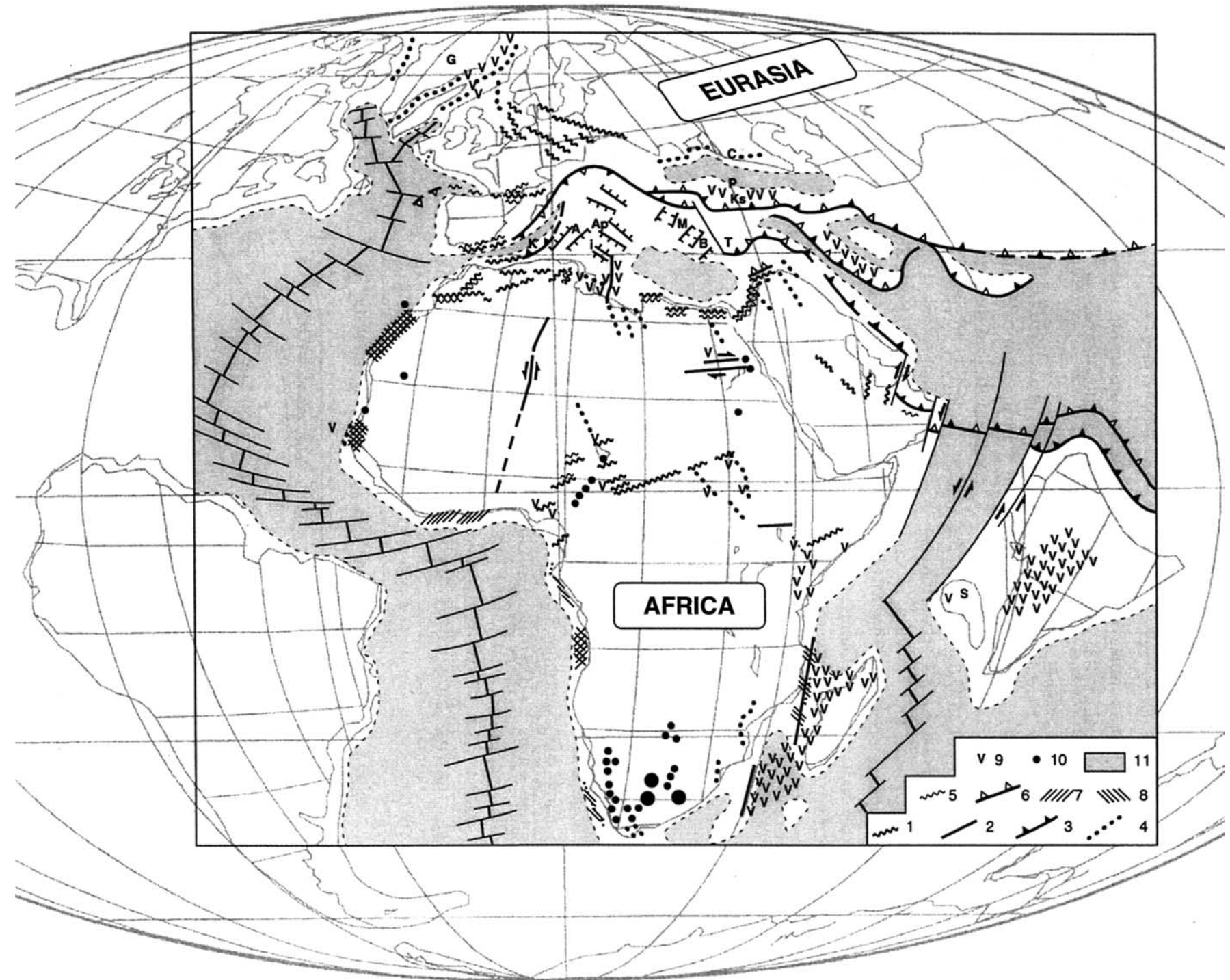

Fig. 51. Senonian tectonic map of Africa-Arabia and adjacent regions. Reconstruction is Cretaceous/Paleocene transition times ( $65 \mathrm{Ma})$. (1) Late Santonian fold belt; (2) major late Santonian fault; (3) late Santonian thrust (early Campanian for Zagros); (4) Campanian-Maastrichtian rift or trough; (5) latest Maastrichtian fold belt; (6) latest Maastrichtian thrust; (7) Santonian/Campanian unconformity; (8) Maastrichtian/Paleocene unconformity; (9) Senonian volcanism; (10) Senonian alkaline anorogenic complex; (11) ocean crust or thinned continental crust. A, Apenninic platform; Ap, Apulia; B, Bey Daglari; C, Caucasus; G, Greenland; I, Iblean domain; K, Kabylie; Ks, Kirsehir; M, Menderes; P, Pontides; S, Seychelles plateau; T, Taurides.

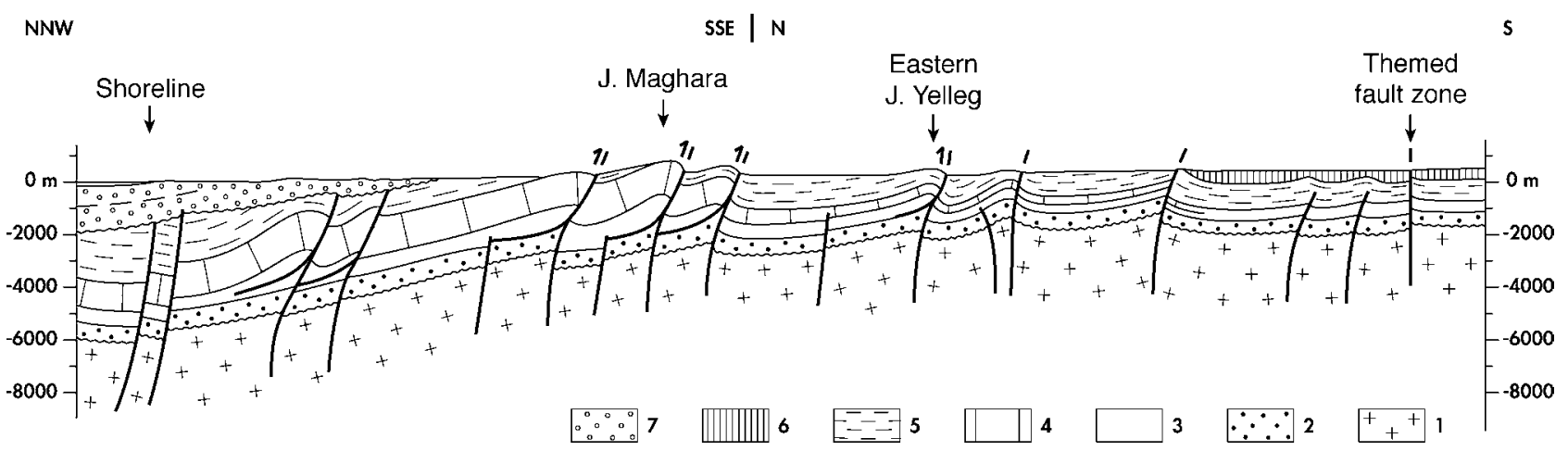

Fig. 52. Schematic geological cross-section along northern Sinai, after Guiraud and Bosworth (1999). Vertical exaggeration $\times 3.6$. (1) Pan-African basement; (2) Paleozoic; (3) Triassic; (4) Jurassic; (5) Cretaceous; (6) Paleocene; (7) Neogene. 

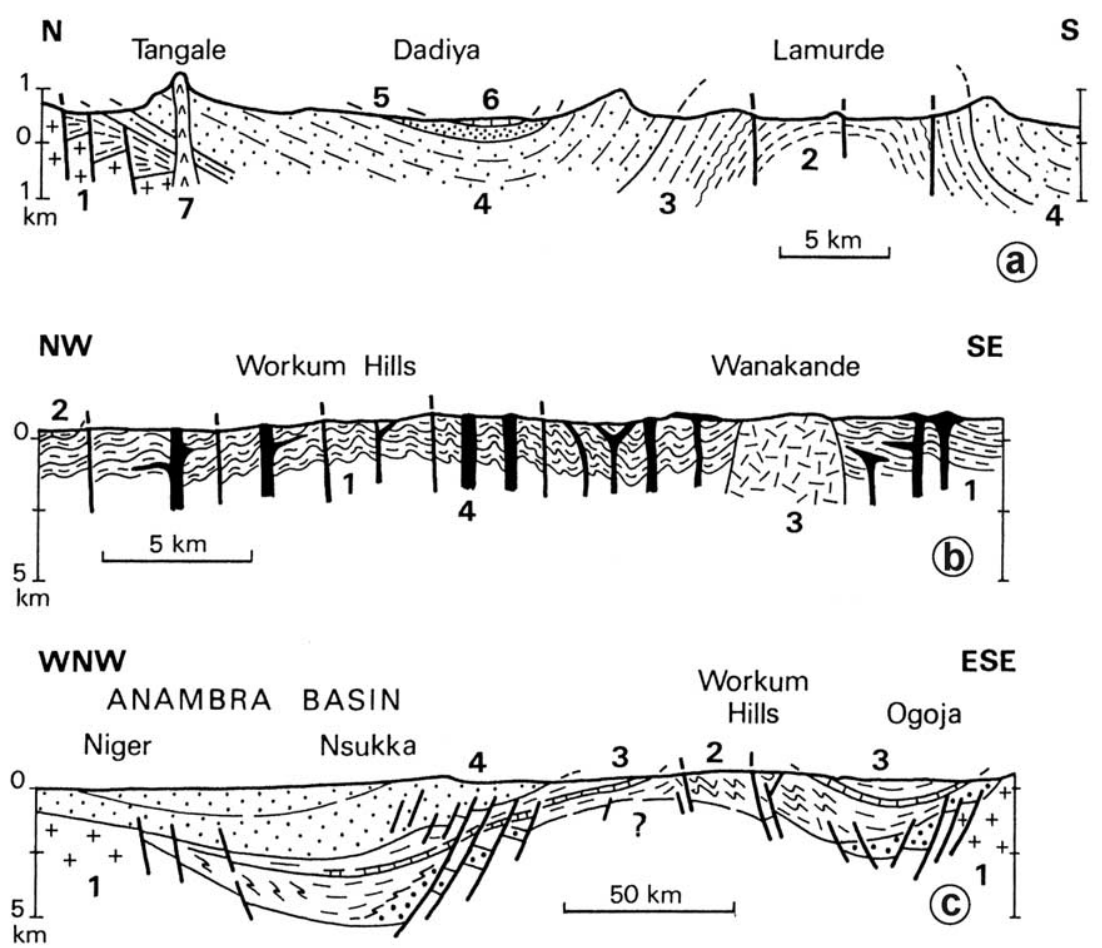

Fig. 53. Geological cross-sections through the Benue fold belt, after Guiraud and Bosworth (1997). (a) Upper Benue: (1) late Precambrian; (2-4) Bima formations (Valanginian/Cenomanian); (5) Yolde Fm. (latest Cenomanian/early Turonian); (6) Dukul Fm. (Turonian); (7) Tertiary trachyte. (b) Abakaliki anticlinorium: (1) Asu River Group (Albian/Cenomanian); (2) Eze Aku Fm. (Turonian); (3) syenite (Albian); (4) dykes and basic lava flows (Cenomanian/early Campanian). (c) Lower Benue Trough: (1) late Precambrian; (2) Aptian/Cenomanian; (3) Turonian/early Coniacian; (4) Campanian/ Maastrichtian.

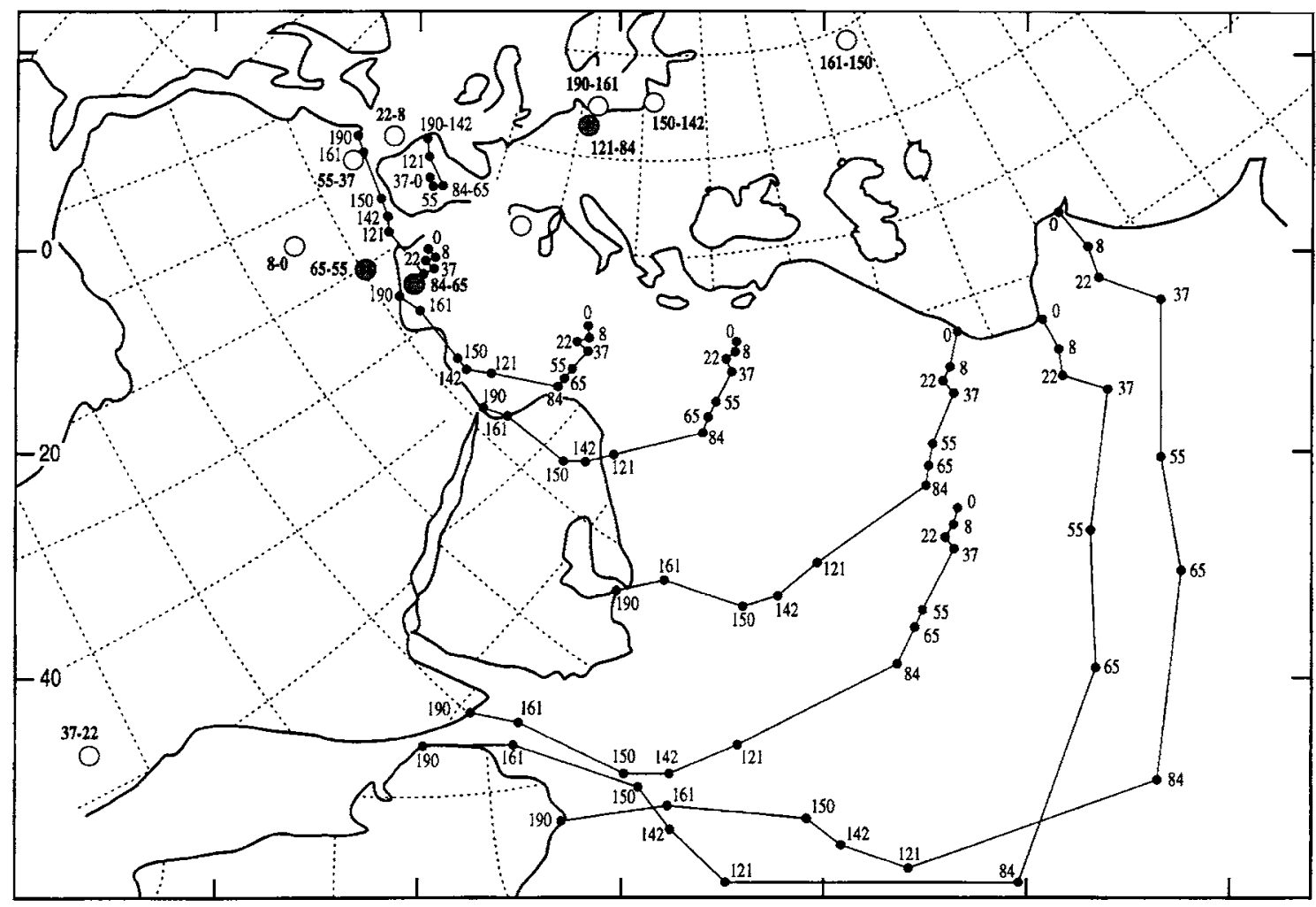

Fig. 54. Relative motion history of Africa, Iberia, Arabia and India with respect to Eurasia from the Early Jurassic (initial fit) to Present time. Stages in Ma. Pole positions describing motion of Africa with respect to Eurasia from stage to stage are shown (positions for 121-84 Ma, 84-65 Ma and 65-55 Ma are underlined). After Guiraud and Bosworth (1997). 


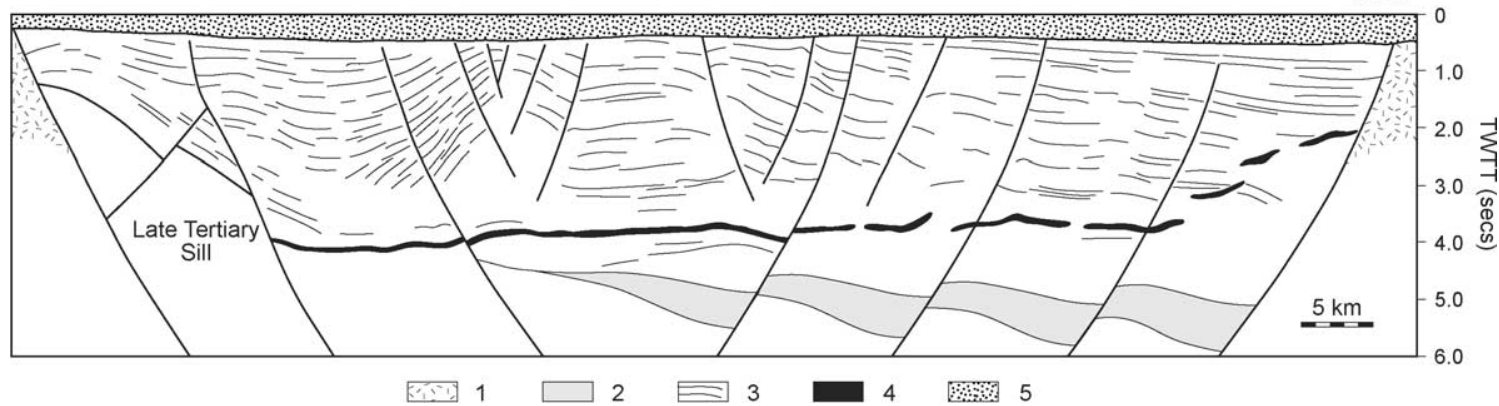

Fig. 55. Geoseismic interpretation of the central Anza Basin, Kenya. Within the basin, a two-way travel time (TWTT) of 3 seconds equals about $4500 \mathrm{~m}$ depth. This upper section has been penetrated by drilling and is completely Late Cretaceous in age and younger. The Late Tertiary sill is based on seismic character and has not been reached. Modified after Bosworth (1992). (1) Crystalline basement; (2) Early Mesozoic syn-rift (conceptual and speculative); (3) Late Cretaceous to Paleogene syn-rift; (4) Late Tertiary intrusive; (5) Miocene to Recent post-rift.

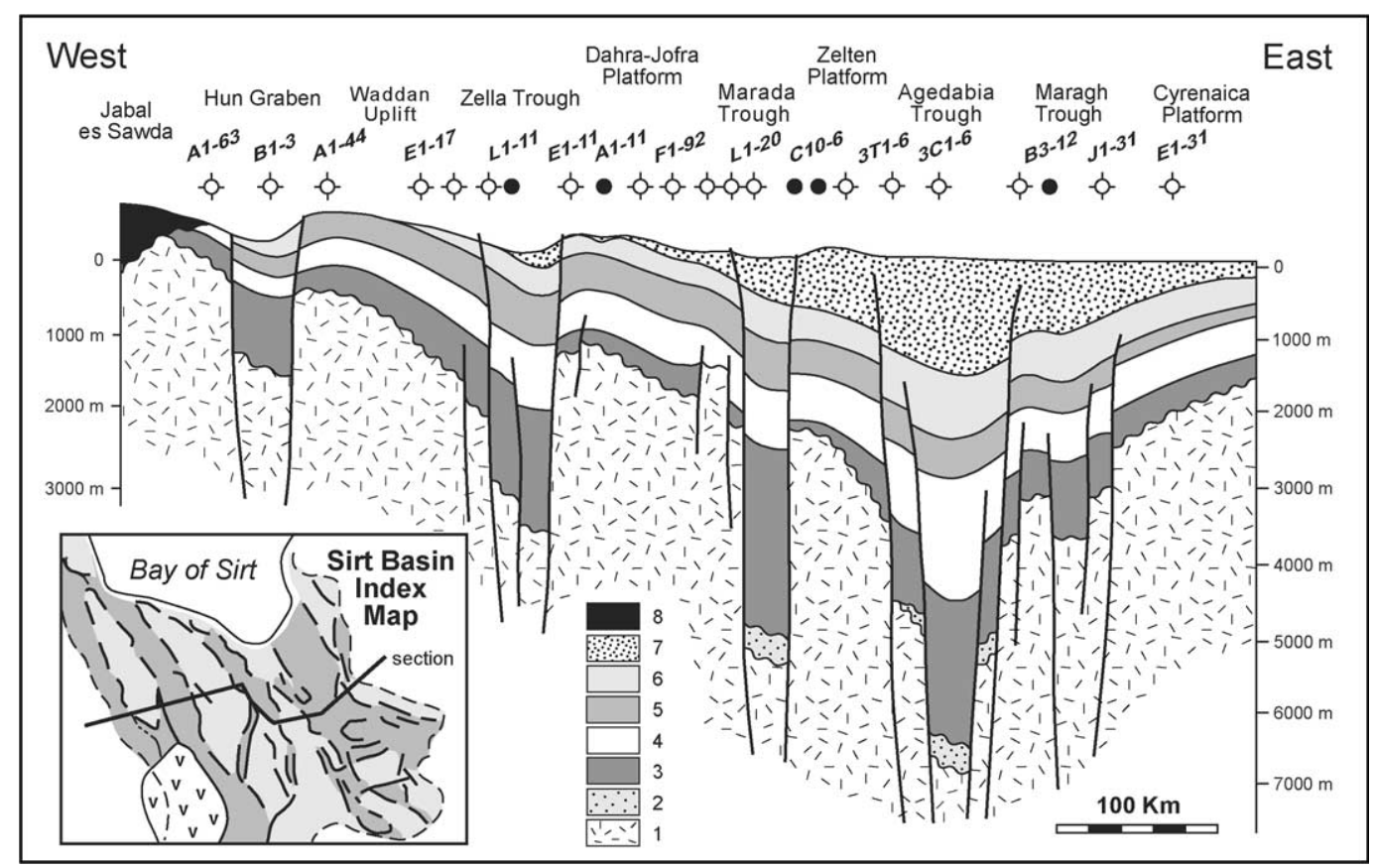

Fig. 56. Schematic geological cross-section of the Sirt Basin, northern Libya, slightly modified from Abuhajar and Roohi (2003). (1) Precambrian basement and Paleozoic quartzites; (2) Lower Mesozoic(?) sandstones; (3) Upper Cretaceous; (4) Paleocene; (5) Lower Eocene; (6) Middle Eocene; (7) Upper Eocene to Recent, (8) Cenozoic volcanics.

affected easternmost Somalia (Guiraud, unpubl.; and illustrations in Fantozzi and Ali Kassim, 2002), and dextral transpression affected the Lugh-Mandera Belt. Gentle folding locally occurred along the southern Arabian plate domain, between Yemen and Oman.

On a plate-scale, the major shortening direction was $\sim \mathrm{N} 160^{\circ} \mathrm{E}$ trending in Africa. Synchronous and similar deformations affected Western Europe (Ziegler, 1990; Ziegler et al., 2001). This event was another major stage in the collision of the African-Arabian and Eurasian plates. Like the Late Santonian event, it resulted from changes in the rates and directions of opening of the Central, South, and North Atlantic oceans (Fig. 54).

\subsection{Late Eocene to recent}

During this last stage, the geological evolution of North and Central Africa was dominated by strong tectonic and magmatic activities, and rapid and intense changes in the global climates. These phenomena resulted in frequent changes in paleoenvironments. The major tectonic events correspond to: (1) the development of the Red Sea-Gulf of Aden-East Africa Rift System that resulted in the separation of the Arabian plate, and (2) the development of the Alpine Belt along the northern African-Arabian plate margin, which was polyphased and generated deformation in the intra-plate domains. The magmatic activity was also 


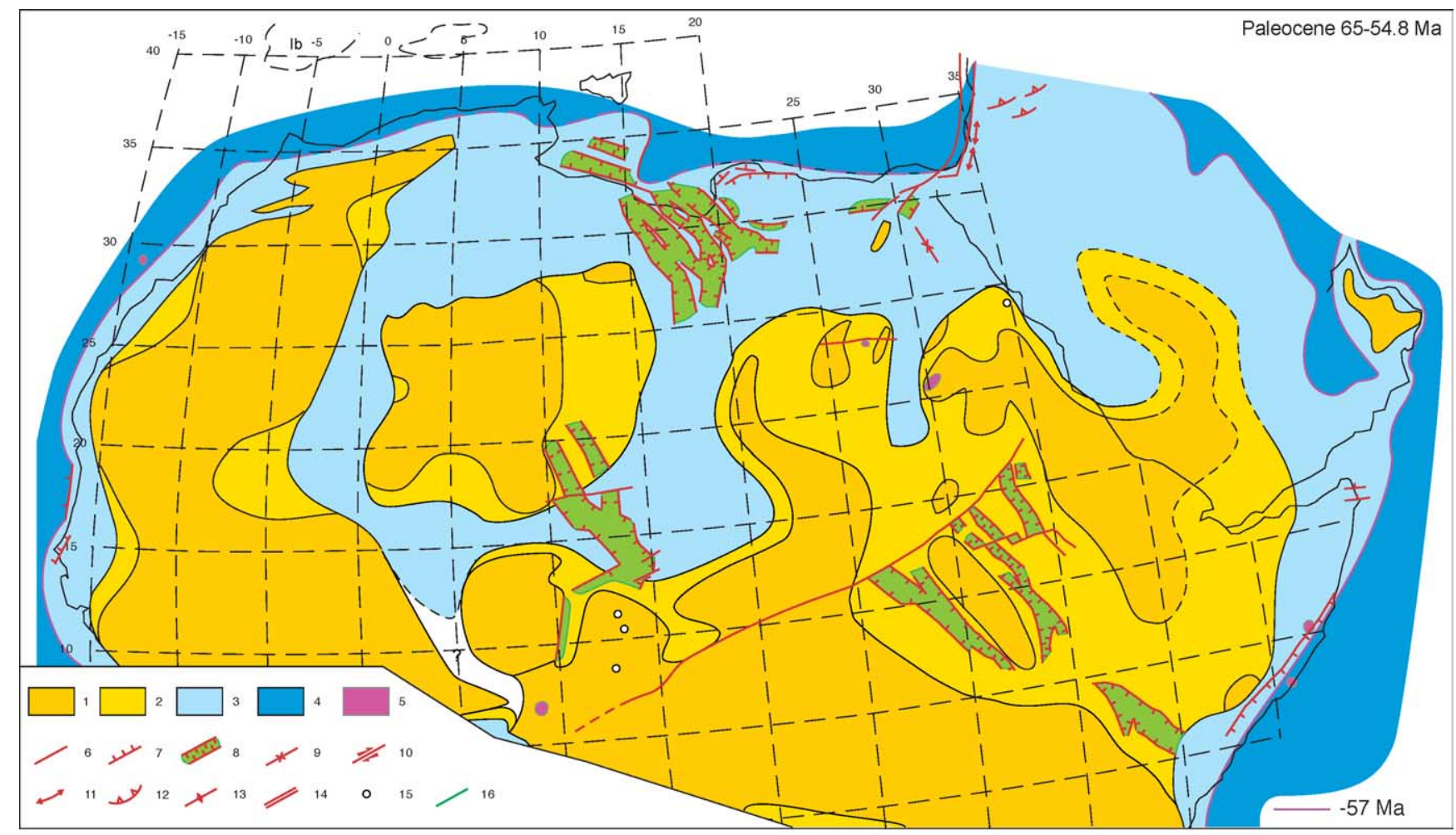

A

Fig. 57A. Paleocene (65-54.8 Ma) paleogeological map, modified from Guiraud (2001). Same legend as Fig. 6.

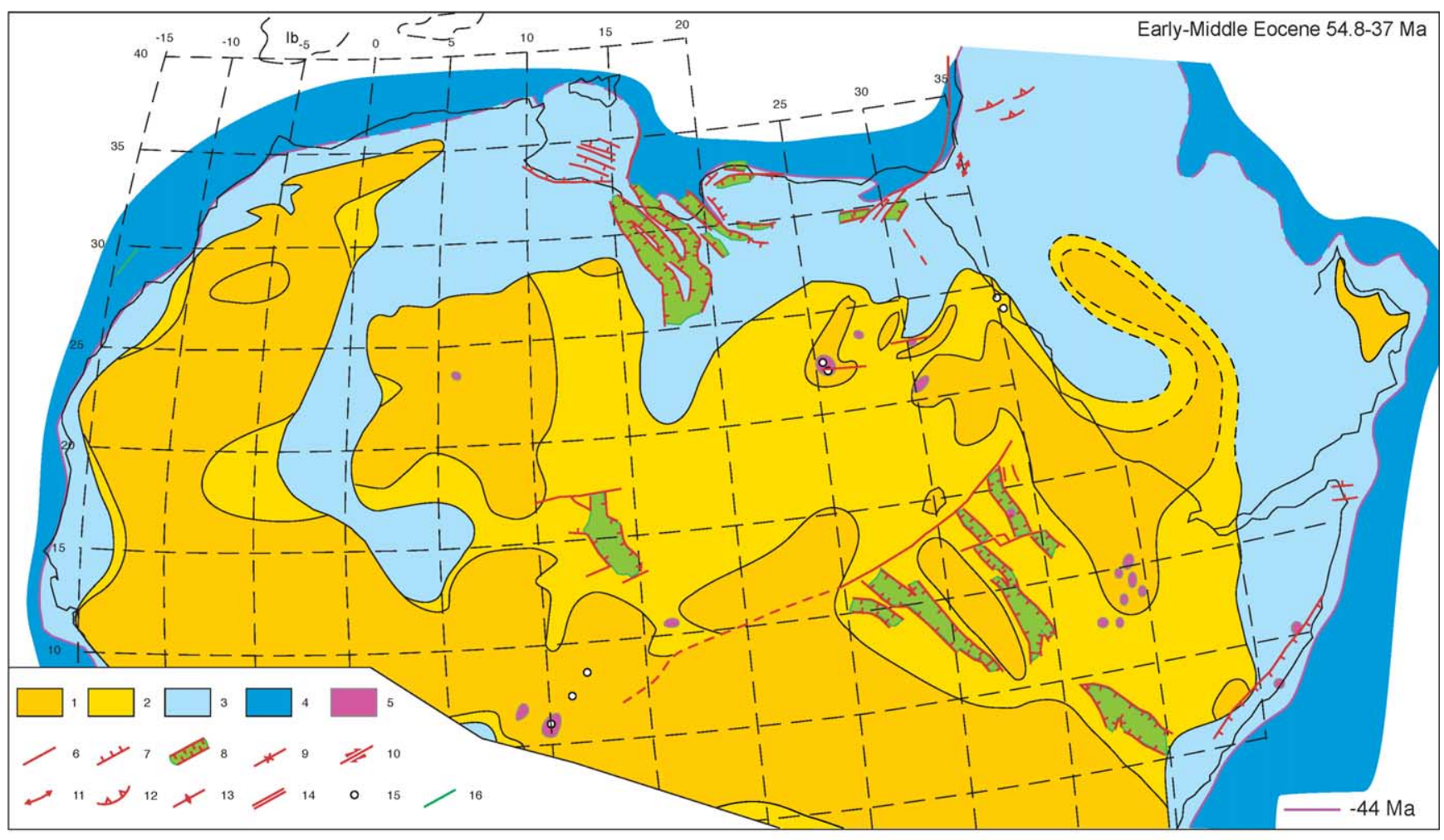

B

Fig. 57B. Early-Middle Eocene (54.8-37 Ma) paleogeological map, modified from Guiraud (2001). Same legend as Fig. 6. 


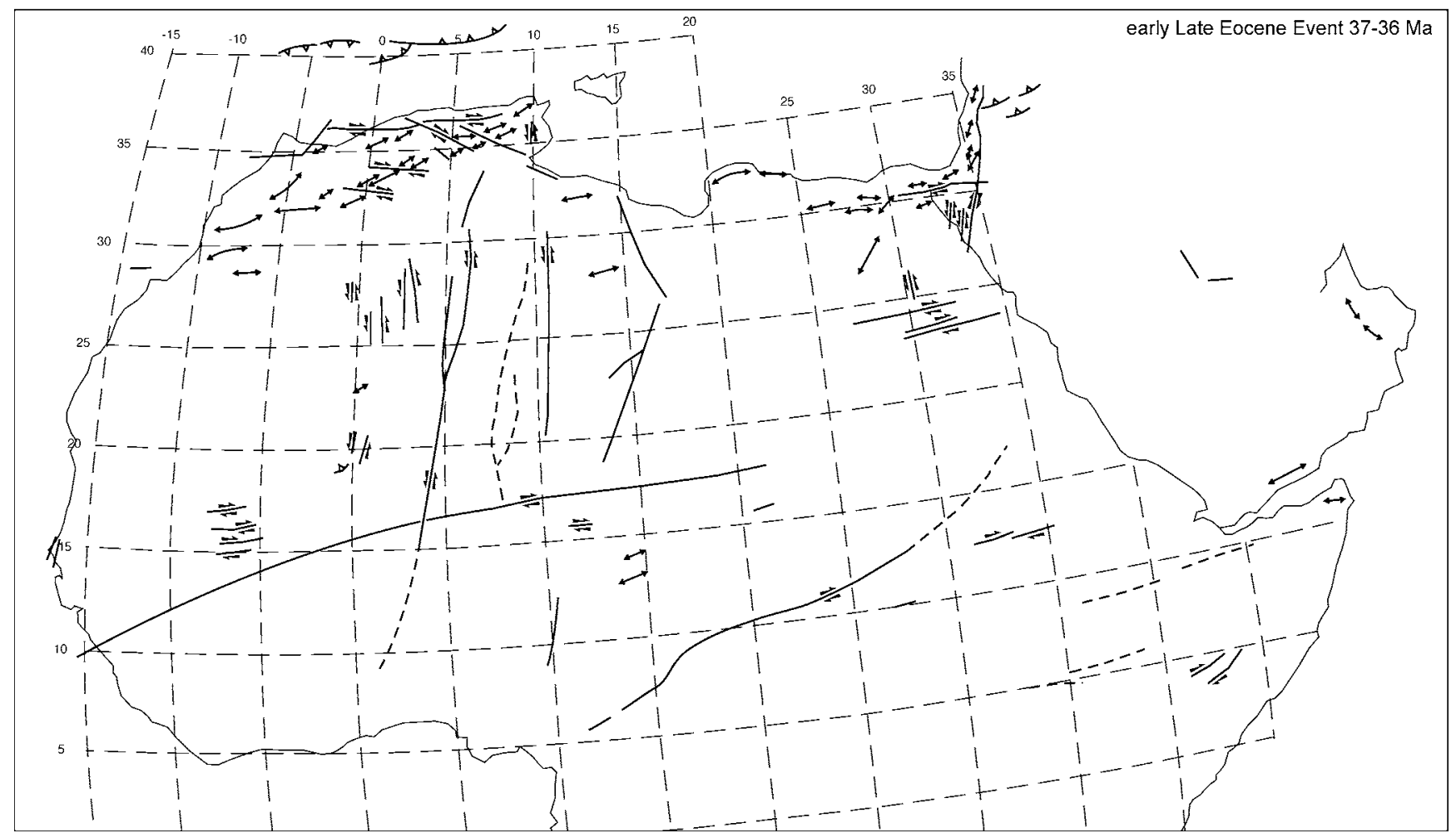

Fig. 58. Early Late Eocene (37-36 Ma) tectonic map, modified from Guiraud (2001). Same legend as Fig. 6.

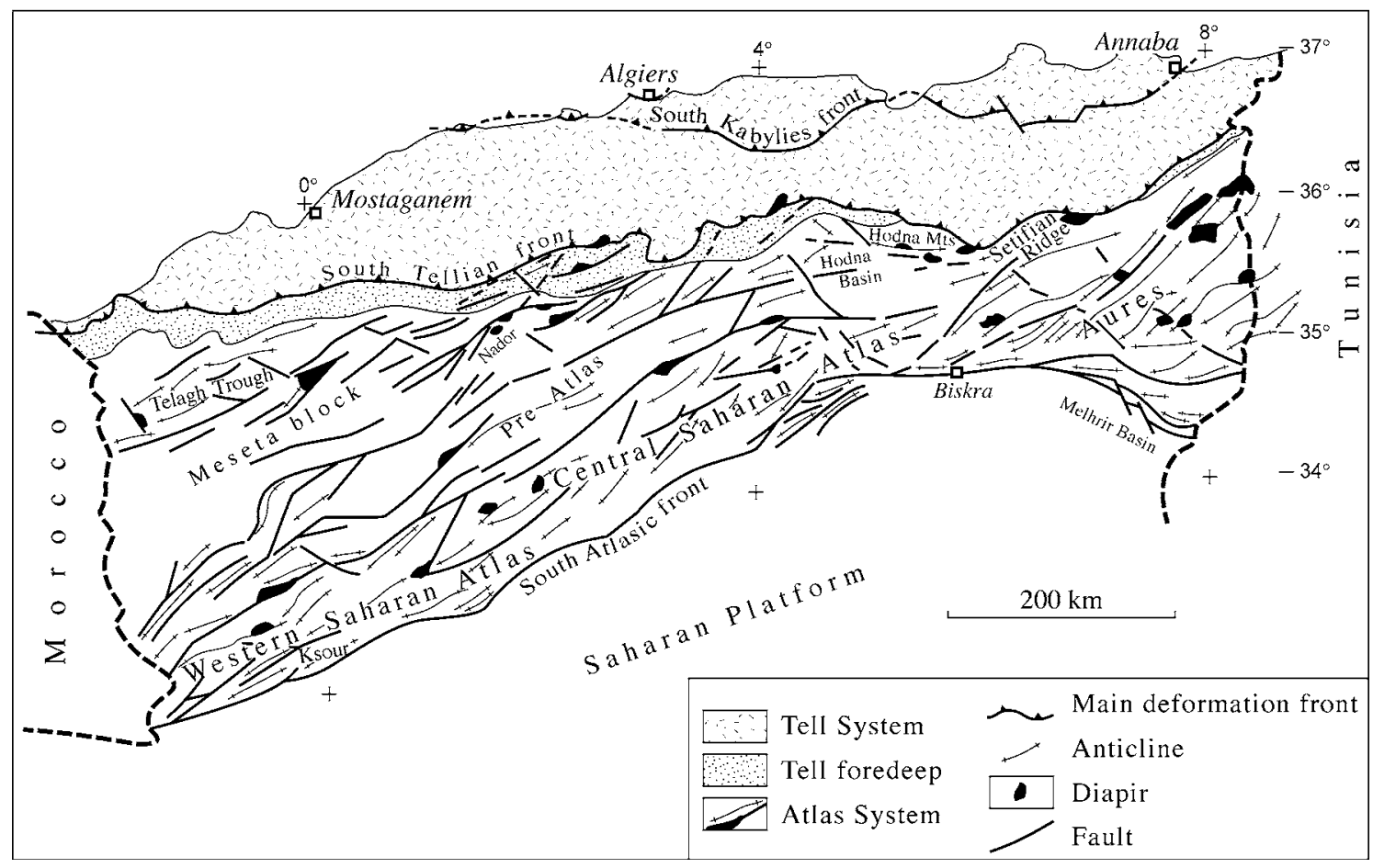

Fig. 59. Tectonic framework of northern Algeria, after Bracène and Frizon de Lamotte (2002).

polyphased and affected large provinces, entailing domal or regional uplifts. The climates registered several periods of strong cooling, resulting in marine regressions and major changes in the continental environments.
We summarize hereafter the main episodes, characteristics, or results of these internal or external geodynamic events. Figs. 26 and 27, and 63A, 63B, 64, provide an illustration of the geological evolution during this stage. 


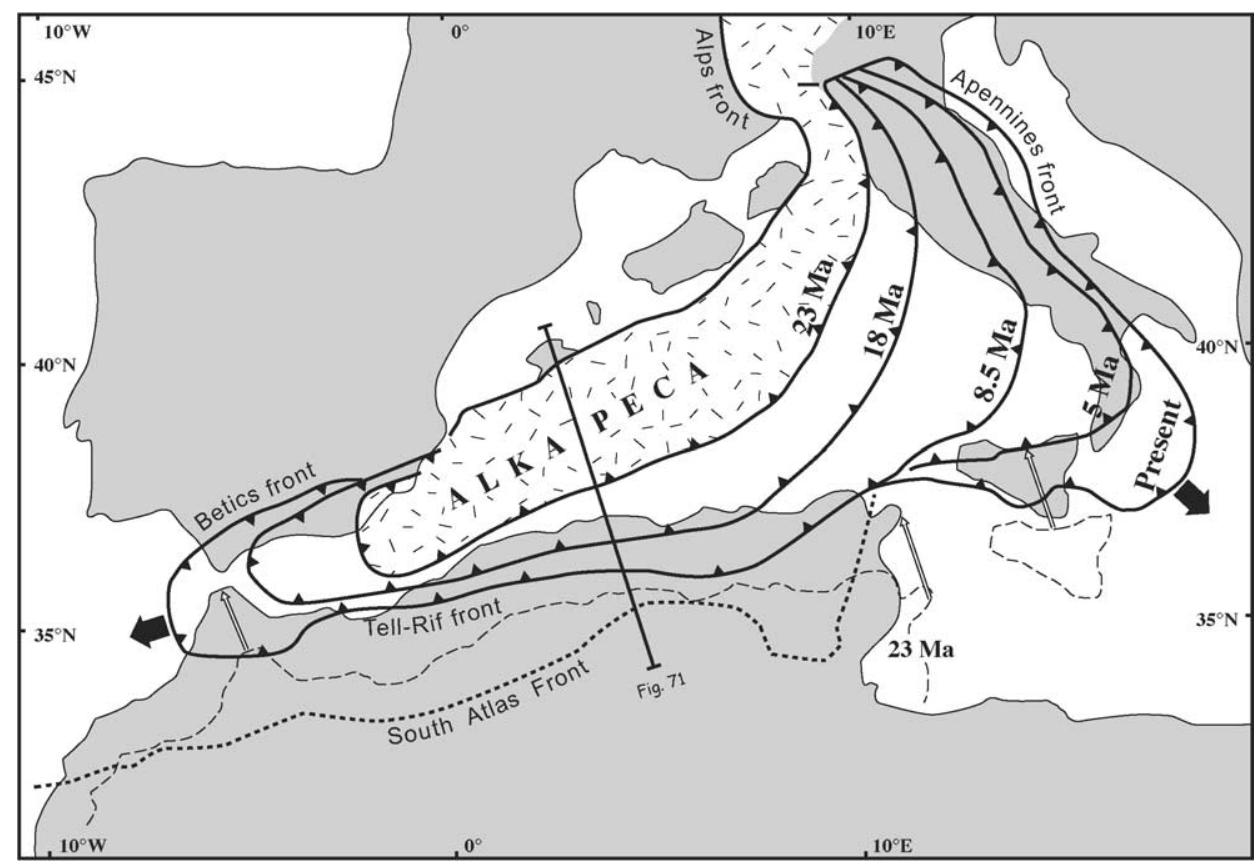

Fig. 60. Palinspastic reconstructions for the Rifian-Tellian domain from 37 Ma to Present, modified from Frizon de Lamotte et al. (2000) and Mauffret et al. (2004). The line with open triangles corresponds to the collisional contact between ALKAPECA (Alboran, Kabylies, Peloritan and Calabria) and the Alpine-Betics Chain around 37 Ma. The line corresponds to location of Fig. 61 transects.

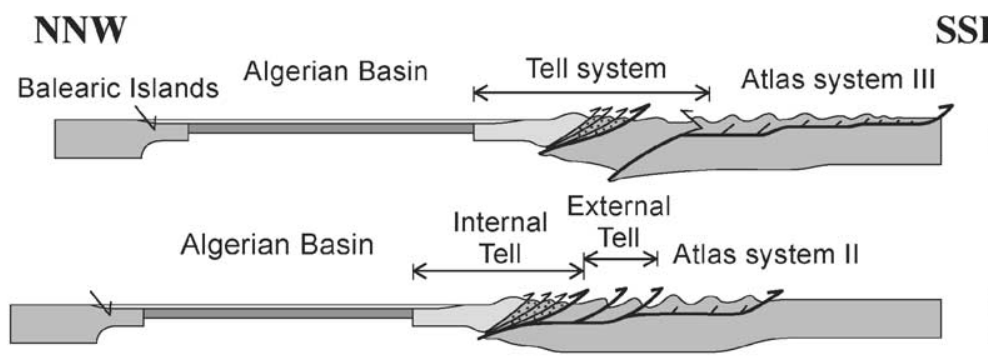

\section{SSE}

Pleistocene

$8.5 \mathrm{Ma}$

Tortonian

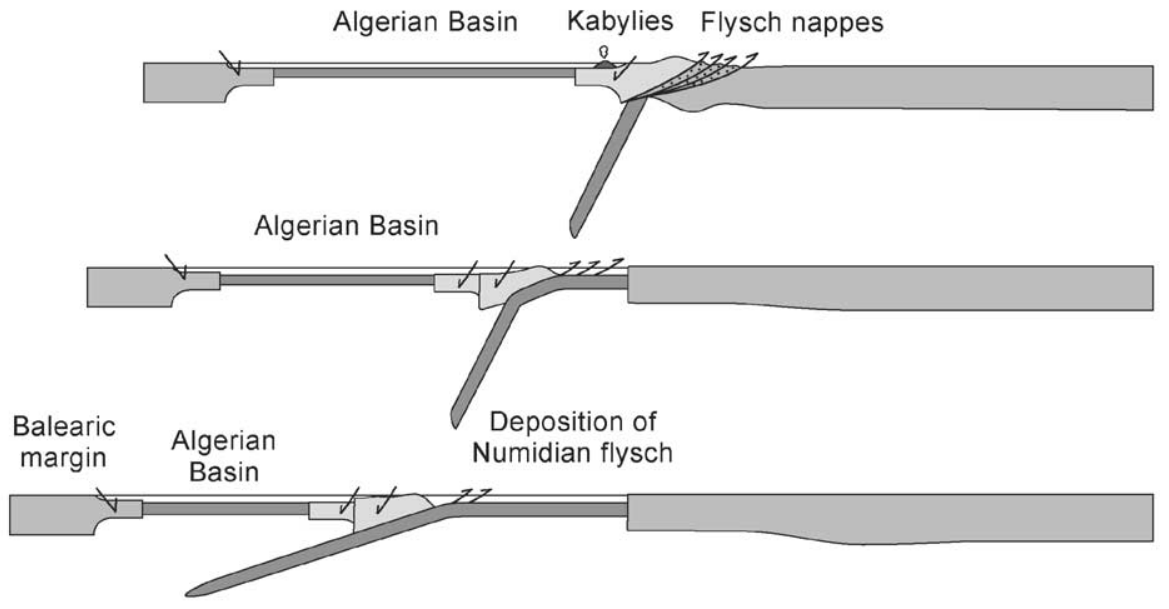

$18 \mathrm{Ma}$

Burdigalian

$21 \mathrm{Ma}$

End Aquitanian

$23 \mathrm{Ma}$

Early Aquitanian

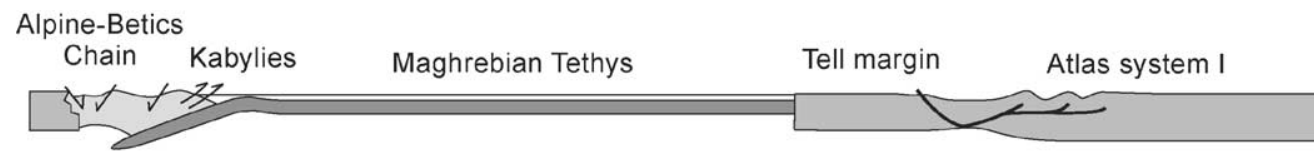

$37 \mathrm{Ma}$

Late Eocene

$\approx 100 \mathrm{~km}$

Fig. 61. Kinematic model of the evolution of the northern Algerian Alpine margin from Late Eocene to Present, modified from Fizon de Lamotte et al. (2000). The transect is located on Fig. 60. 


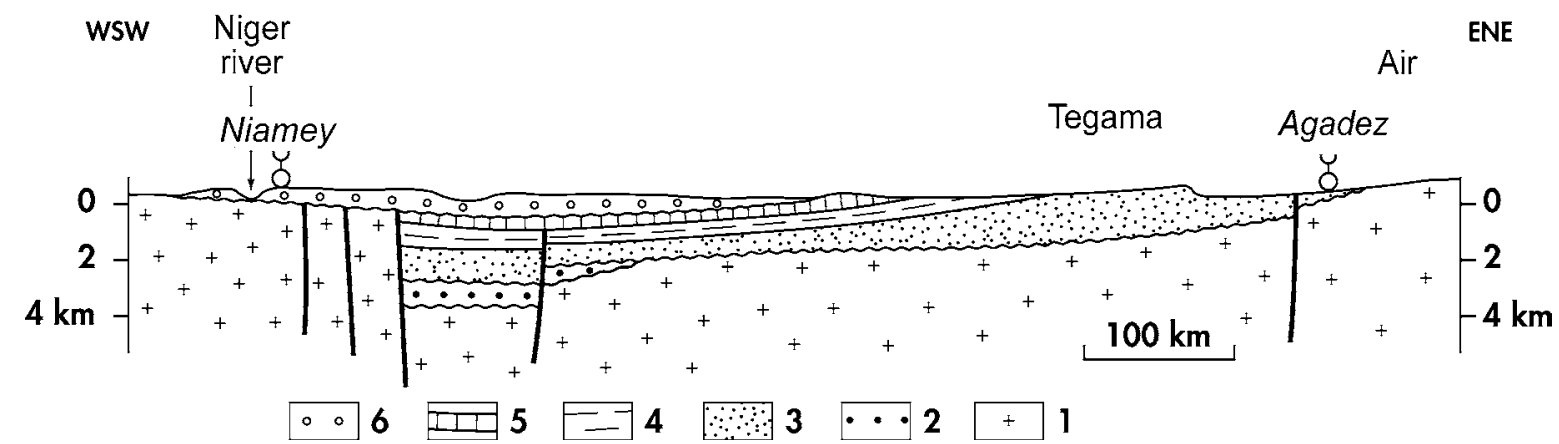

Fig. 62. Geological cross-section of the western Niger, Iullemmeden Basin. (1) Pan-African; (2) Paleozoic; (3) Triassic-Early Cretaceous; (4) Late Cretaceous; (5) Paleocene-Middle Eocene; (6) "Continental terminal".

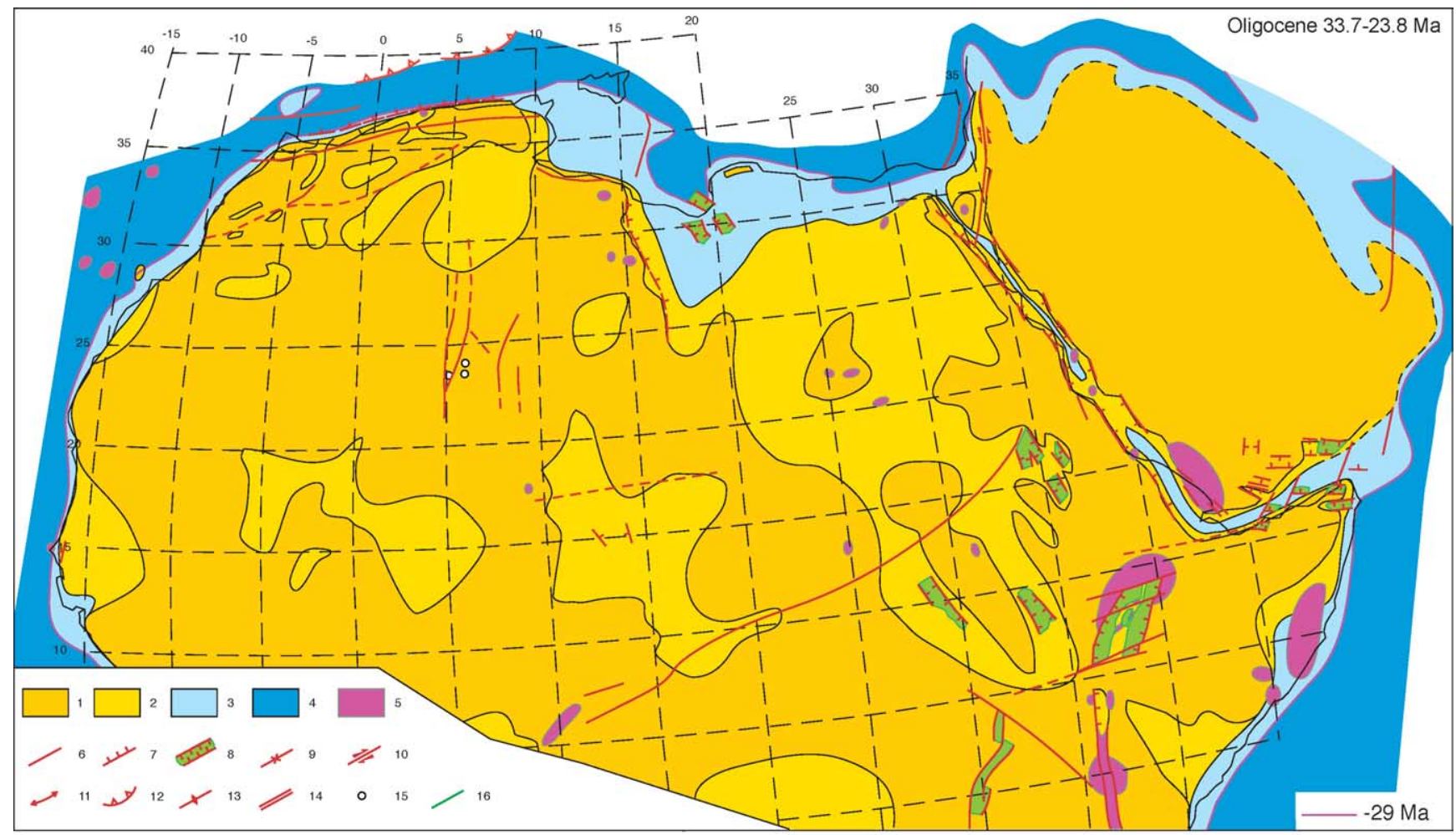

A

Fig. 63A. Oligocene (33.7-23.8 Ma) paleogeological map, modified from Guiraud (2001). Same legend as Fig. 6.

\subsubsection{Rifting and opening of the Gulf of Aden-Red Sea ocean}

Along the NW-SE trending troughs of eastern Niger and central Sudan, rifting temporarily and locally rejuvenated, while minor troughs developed in eastern Sudan (Figs. 63A, 63B, 64). The main event, however, was the initiation and development of large rift basins along the future Gulf of Aden, Red Sea, and East African Lakes provinces. The opening of narrow, elongated oceanic domains along the Gulf of Aden and the Red Sea from Miocene times resulted in the separation and northwards drift of the Arabian plate, allowed by sinistral movement along the Levant-Dead Sea fault zone. These events are described in detail in this special issue by Bosworth et al. and Chorowicz. We therefore only mention hereafter the main characteristics for our overview.

Rifting initiated in the Early Oligocene (Rupelian) in several small, en echelon $\sim \mathrm{E}-\mathrm{W}$ to ESE-WNW trending basins in the Gulf of Aden province (Fantozzi and Sgavetti, 1998; Watchorn et al., 1998) (Fig. 63A). By the OligoceneMiocene transition, rifting had spread to Afar and throughout the Red Sea system (Bosworth et al., this issue). Onset of extension in the Main Ethiopian Rift (MER) is difficult to constrain as the appropriate stratigraphic section is generally covered by younger volcanic rocks. However, field relationships and ${ }^{40} \mathrm{Ar} /{ }^{39} \mathrm{Ar}$ age dates from the southern MER suggest that rifting commenced during the Early to early Middle Miocene ( 18-14 Ma) (Ebinger 


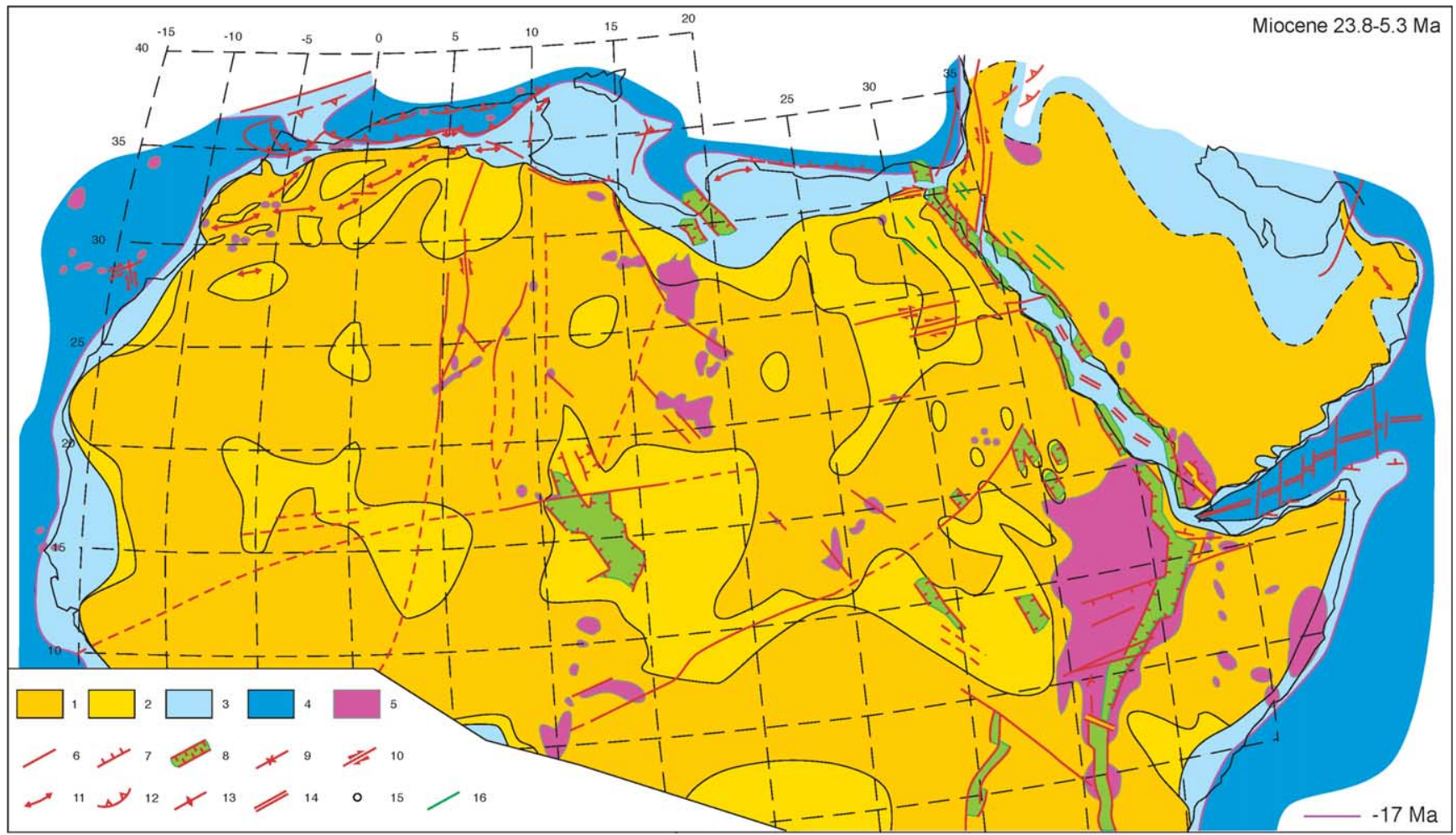

B

Fig. 63B. Miocene (23.8-5.3 Ma) paleogeological map, modified from Guiraud (2001). Same legend as Fig. 6.

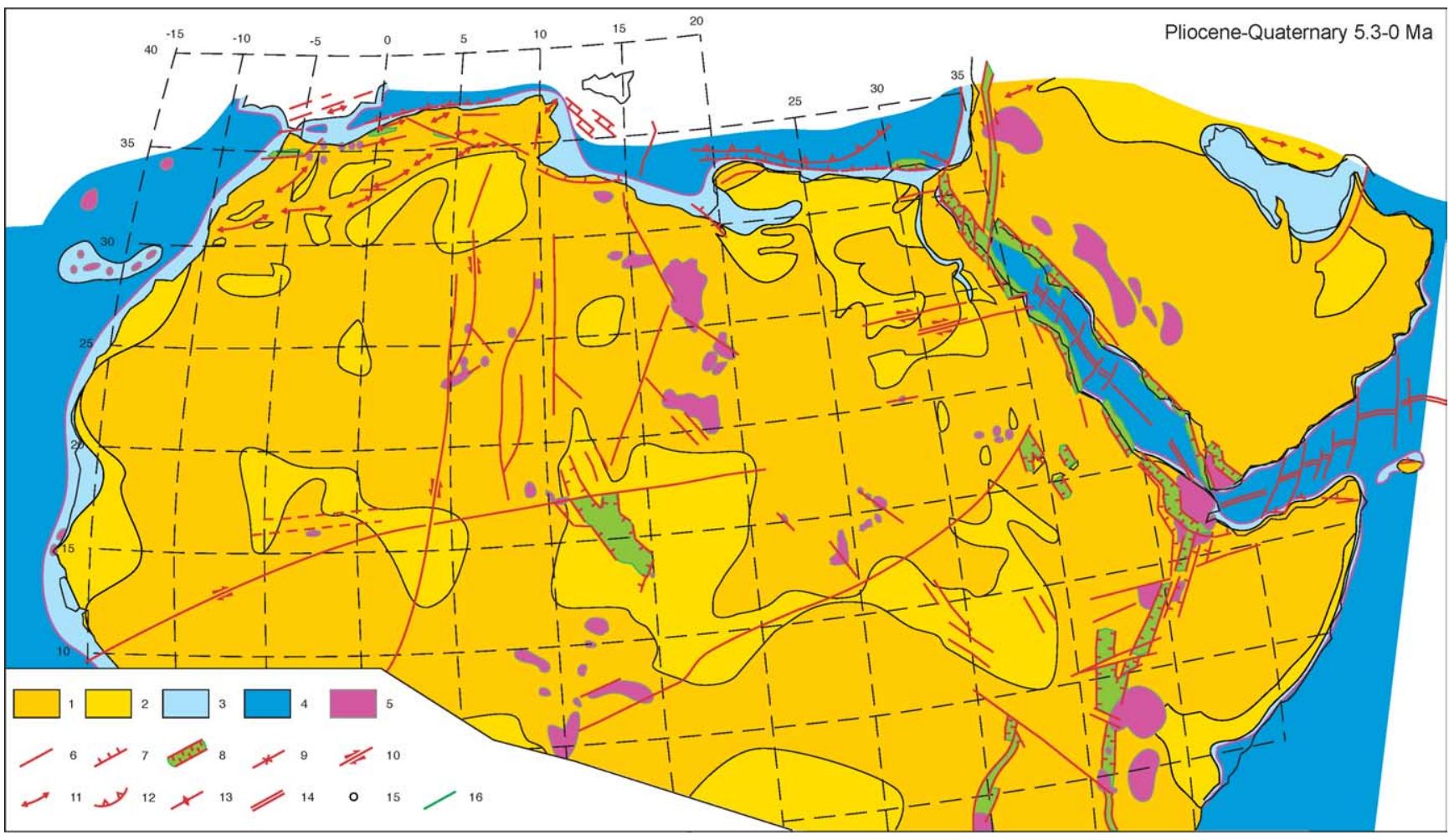

Fig. 64. Pliocene-Quaternary (5.3-0 Ma) paleogeological map, modified from Guiraud (2001). Same legend as Fig. 6.

et al., 1993). Subsequently, the regions of extension spread and half-grabens or grabens developed throughout the East
African Lakes domain (Fig. 63B). Thick series of continental terrigenous sediments accumulated in the East African 


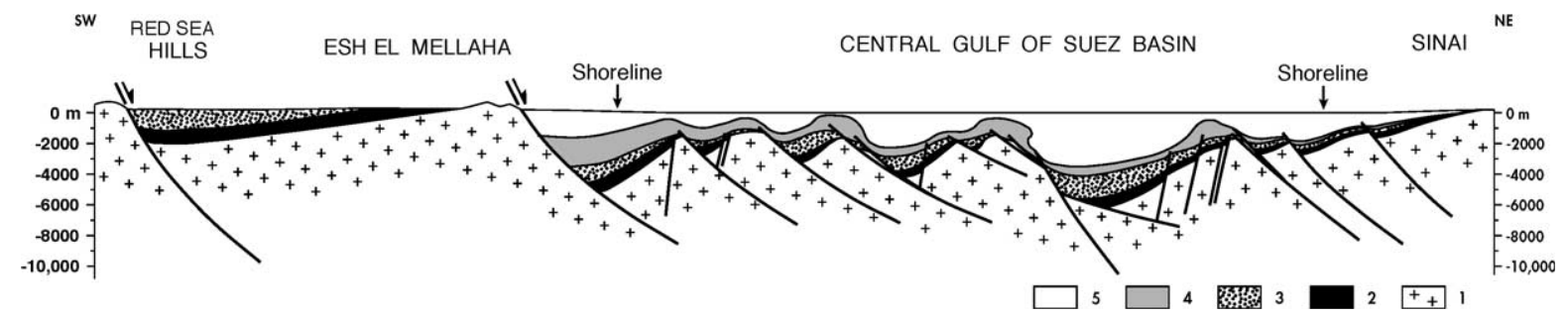

Fig. 65. Geological cross-section of the southern Gulf of Suez, after Guiraud and Bosworth (1999). No vertical exaggeration. (1) Pan-African basement; (2) Cambrian-Eocene; (3) Late Oligocene-Middle Miocene; (4) Middle to Late Miocene salt; (5) Late Miocene-Recent.

Lakes rifts. Marine and marginal marine sedimentation predominated in the Gulf of Aden-Red Sea-Gulf of Suez rifts, overlain by Middle to Late Miocene evaporites (Figs. 63B and 65). The main phase of shear along the Dead Sea fault zone initiated during the Middle Miocene (reviewed in Bosworth and McClay, 2001; Bosworth et al., this issue), in response to final suturing of Arabia to Eurasia along the Bitlis-Zagros thrust belt and active seafloor spreading in the Gulf of Aden. Strong magmatic activity predated and accompanied rift tectonics, favoring extension by weakening the lithosphere (see Wilson and Guiraud, 1998; and hereafter).

\subsubsection{Compressional events and deformations}

The collision between the African-Arabian and Eurasian plates episodically intensified from the earliest Miocene times. A new change in plate motions occurred around $22 \mathrm{Ma}$, as Africa then began to move northeastwards (Fig. 54). This change, synchronous with the opening of the Western Algerian-East Alboran ocean basin (Mauffret et al., 1992) (Fig. 61), generated compressional deformations during the Burdigalian along the northwestern African plate margin. The Kabylies were accreted to Africa, while the external domain of the Rifian-TellianSicily Belt registered southwards thrusting (Vila et al., 1995). The Maghrebian Alpine foreland also experienced slight NE-SW shortening (Letouzey and Trémolières, 1980), as well as the intra-plate weakened zone of the Guinean-Nubian lineaments (Bellion et al., 1984; Guiraud and Bellion, 1995). NE-SW trending igneous dykes, parallel to the maximum shortening direction, initiated in the Hoggar Massif (Aït-Hamou, 2000). Minor folding and shearing affected the northern Arabian plate margin, both along the Syrian Arc (Lovelock, 1984) and in Oman (Rabu et al., 1993).

During the Tortonian $(\sim 8.5 \mathrm{Ma})$, the African plate motion changed again and became northwestward directed (Fig. 54). This generated dextral transpression along the northern African-Arabian plate margin (Guiraud and Bellion, 1995). The last thrusting episode occurred along the southern Rifian-Tellian front of the Maghrebian Alpine Belt (Guiraud et al., 1987; Vila et al., 1995; Frizon de Lamotte et al., 2000) (Figs. 61 and 63B), while folding developed in the foreland, e.g., in Tunisia (Figs. 23 and 66). E-W trending dextral fault zones and associated

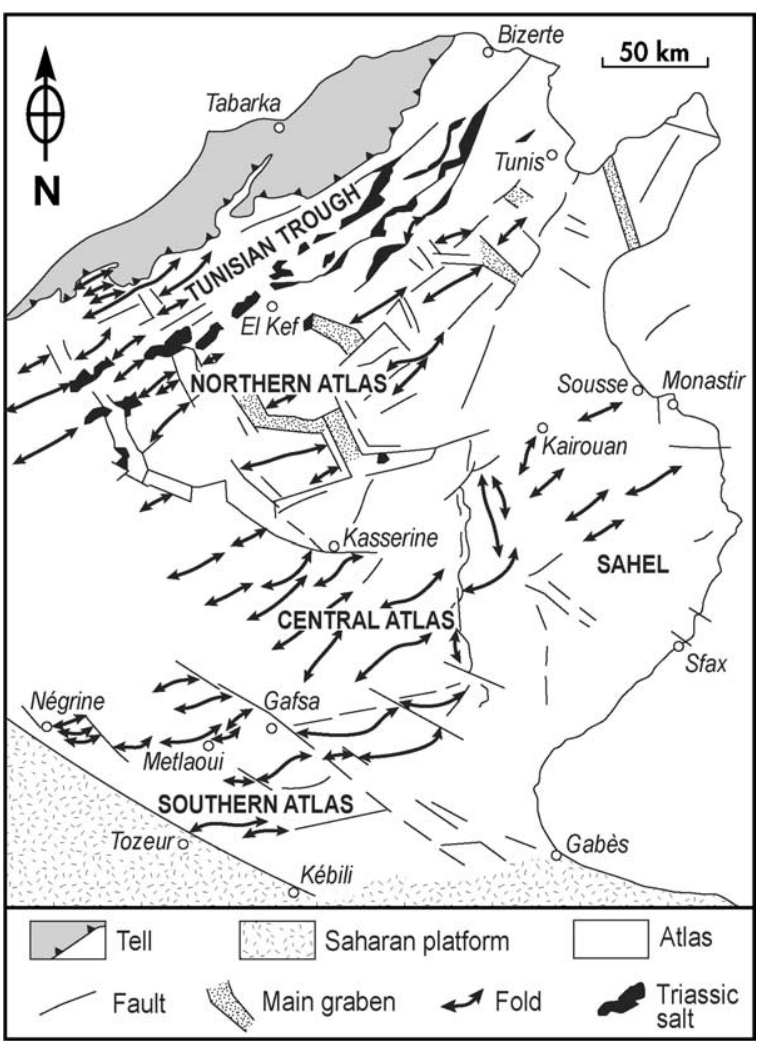

Fig. 66. Schematic tectonic map of the Tunisian Atlas, slightly modified after Piqué (2001).

pull-apart basins developed on the Pelagian shelf and within the Bay of Sirt. Folding and strike-slip movement developed along the Levant area in response to $\mathrm{N} 110^{\circ} \mathrm{E}$ shortening (Letouzey and Trémolières, 1980). Some major intra-plate fracture zones were rejuvenated, e.g., in northern Hoggar, southern Egypt, and central-eastern Sudan (Fig. 63B).

Finally, an early Pleistocene event occurred in AfricaArabia, characterized by well-documented NW-SE to $\mathrm{N}-\mathrm{S}$ shortening along the northwestern African margin (Guiraud, 1986, 1990; Frizon de Lamotte et al., 2000). $\sim \mathrm{E}-\mathrm{W}$ folds and reverse faults developed, associated with NW-SE dextral and NNE-SSW sinistral strike-slip faults. The present-day Alpine Belt was then largely emplaced (Fig. 67). Major intra-plate fault zones were rejuvenated and regional uplifts intensified (Fig. 64). With time the 

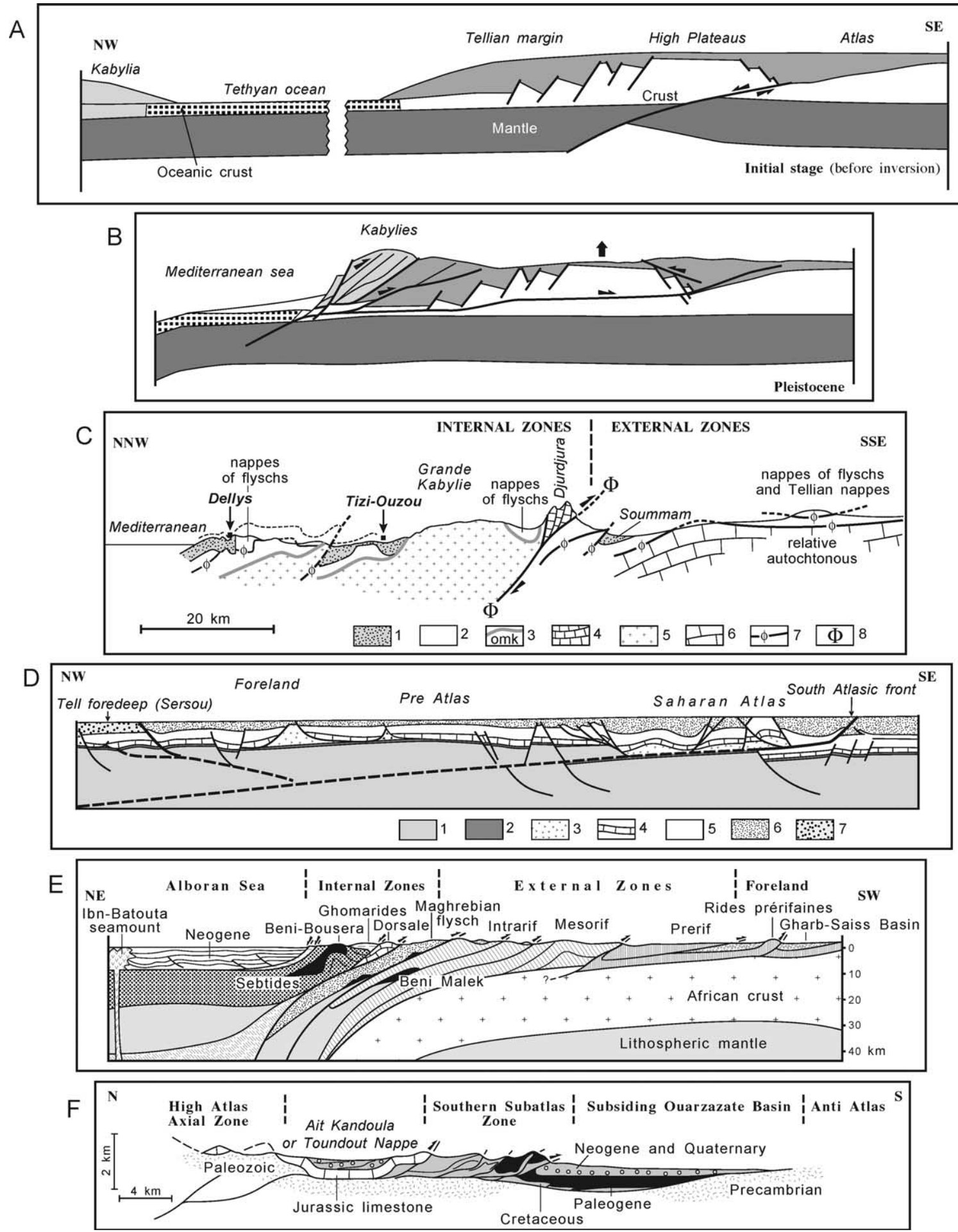

Fig. 67. Schematic geological cross-sections of the Maghrebian Alpine Belt. (A) Central Northern Algeria (initial stage), after Bracène and Frizon de Lamotte (2002). (B) Central Northern Algeria (Present-day), after Bracène and Frizon de Lamotte (2002). (C) Great Kabylia and foreland, after Aité and Gélard (1997). (1) Post-nappes Neogene; (2) allochthonous formations; (3) "Oligo-Miocène Kabyle" (omk); (4) limestone Djurdjura Range; (5) PanAfrican and Hercynian Kabylian basement; (6) Mesozoic autochthonous; (7) thrust fault; (8) main thrust fault. (D) Saharan Atlas and Pre-Atlas, after Bracène and Frizon de Lamotte (2002). (1) Paleozoic basement; (2) Triassic sandstones; (3) Triassic evaporites; (4) Liassic; (5) Middle and Late Jurassic; (6) Cretaceous; (7) Cenozoic. (E) Rif, after Chalouan and Michard (2004). (F) Southern High Atlas, after El Harfi et al. (2001). Location of cross-sections $\mathrm{C}$ to $\mathrm{F}$ on Fig. 30.

intensity of shortening strongly decreased, but the northward motion of the African and Arabian plates continued on up to the present as evidenced by satellite measurements, neotectonic analyses, and seismicity. 


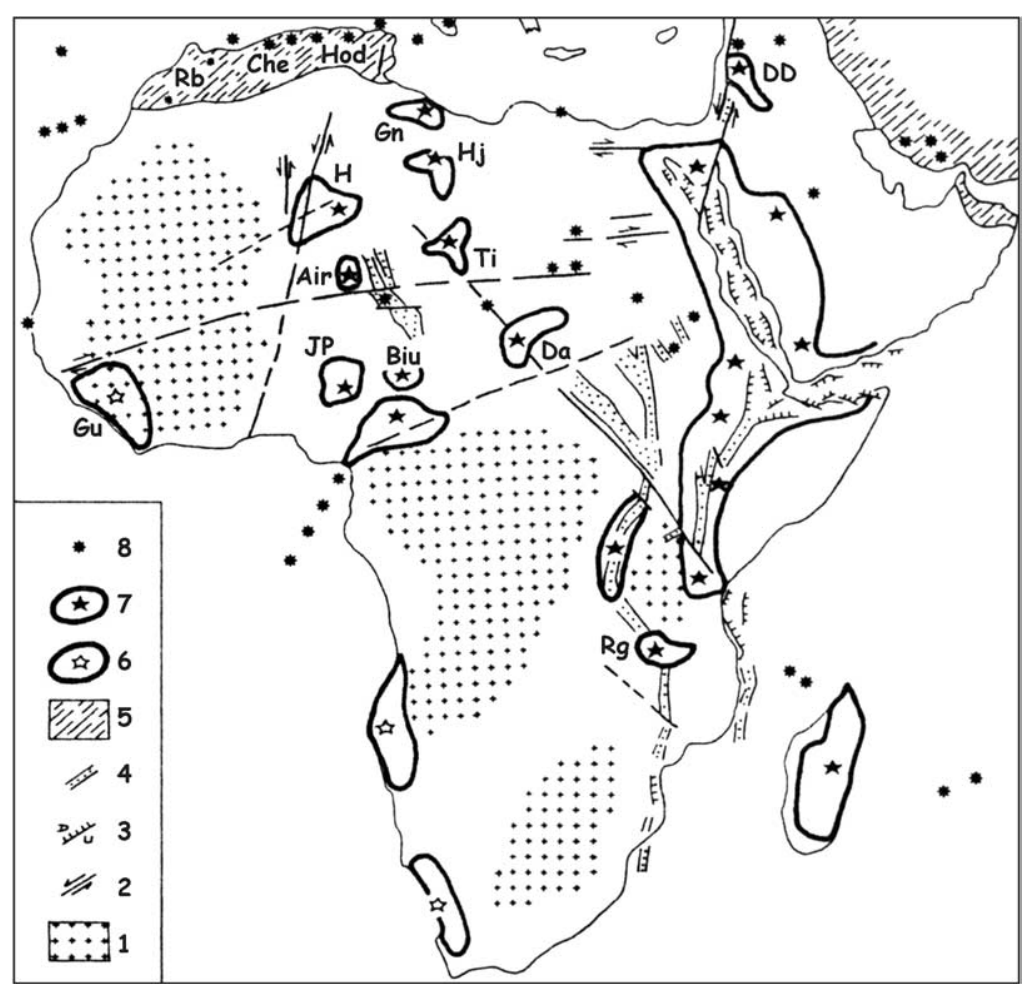

Fig. 68. Late Eocene to Recent rifting, uplift and magmatism in Africa and Arabia. Schematic map after Guiraud and Bellion (1995). (1) Cratonic area; (2) strike-slip fault; (3) fault (down, up); (4) rift; (5) Alpine belt; (6) uplifted area; (7) area of uplift and magmatism; (8) volcanoes. Che, Cheliff; Da, Darfur; DD, Dj. Druze; Gn, Garian High; Gu, Guinea; H, Hoggar; Hj, Haruj; Hod, Hodna; JP, Jos Plateau; Rb, Rharb; Rg, Rungwe; Ti, Tibesti.

\subsubsection{Magmatic activity}

Large intra-plate magmatic provinces initiated or developed in several areas in Africa-Arabia, including Red SeaGulf of Aden-East Africa, the Druze Province in Jordan and Syria, the Darfur, Tibesti, and Hoggar-Air massifs, the Jos Plateau (Nigeria), and the Cameroon Line-Adamawa Plateau (Wilson and Guiraud, 1992, 1998) (Figs. 63A, 63B, 64). Flood basalts covered large areas in western Libya (Jebels el Haruj, Garian, etc.). All these provinces registered regional uplifts associated with magmatic intrusions (Fig. 68). Magmatism was also active along the Alpine margins of northwestern Africa and northern Arabia, and the volcanic archipelagos and rises of the West African passive margin (Madera, Canary, Cabo Verde, Sierra Leone Rise) were initiated or further developed.

Magmatism was alkaline in composition, although some calk-alkaline intrusions also occurred in the Alpine Belt. The greatest activity was registered during the Early Miocene (Wilson and Guiraud, 1998). Concerning the relationship between magmatism and rifting, two different domains must be distinguished (Guiraud et al., 1992): (1) the Red Sea-East African domain, where magmatism accompanied rifting, even if dike swarms and volcanic activity developed more along the rift shoulders than in the troughs; and (2) the west-central African area, where most of the volcanic fields lay far from the rifted Mesozoic-Cenozoic basins, often occurring where fracture zones cut across domal structures that probably overlie localized mantle upwellings.

\subsubsection{Paleogeographical and paleoenvironmental evolution}

The late Eocene "Pyrenean-Atlasic" compressional event generated relief along the Tethyan African-Arabian margin and large uplifts in the intra-plate domain. As a result, the size of the remaining intra-plate sedimentary basins was reduced and this tendency intensified later on in response to younger compressional events and development of large uplifted magmatic provinces (Figs. 63A, 63B, 64). Seas no longer invaded the intra-continental basins that underwent fluviatile-lacustrine sedimentation (Fig. 26) resulting in the deposition of conglomerates, sandstones and shales corresponding to the so-called "Continental terminal" formations (Kilian, 1931; Guiraud, 1978; Lang et al., 1990). The Red Sea-Gulf of Aden-East African Lakes domains, however, exhibited different sedimentary patterns (see Bosworth et al., this issue; Chorowicz, this issue).

Along the marine platforms surrounding Western and Northern Africa, terrigenous sedimentation dominated except during middle Miocene times when warmer climates produced marine transgression and carbonate deposition. Around northern and eastern Arabia carbonate platforms prevailed during the Oligocene and Miocene times. In other respects, a few drastic events must be underlined:

- the strong drop in the global sea level that occurred in the earliest Oligocene in conjunction with a glacial episode, which resulted in the emersion of most of the shelves; 


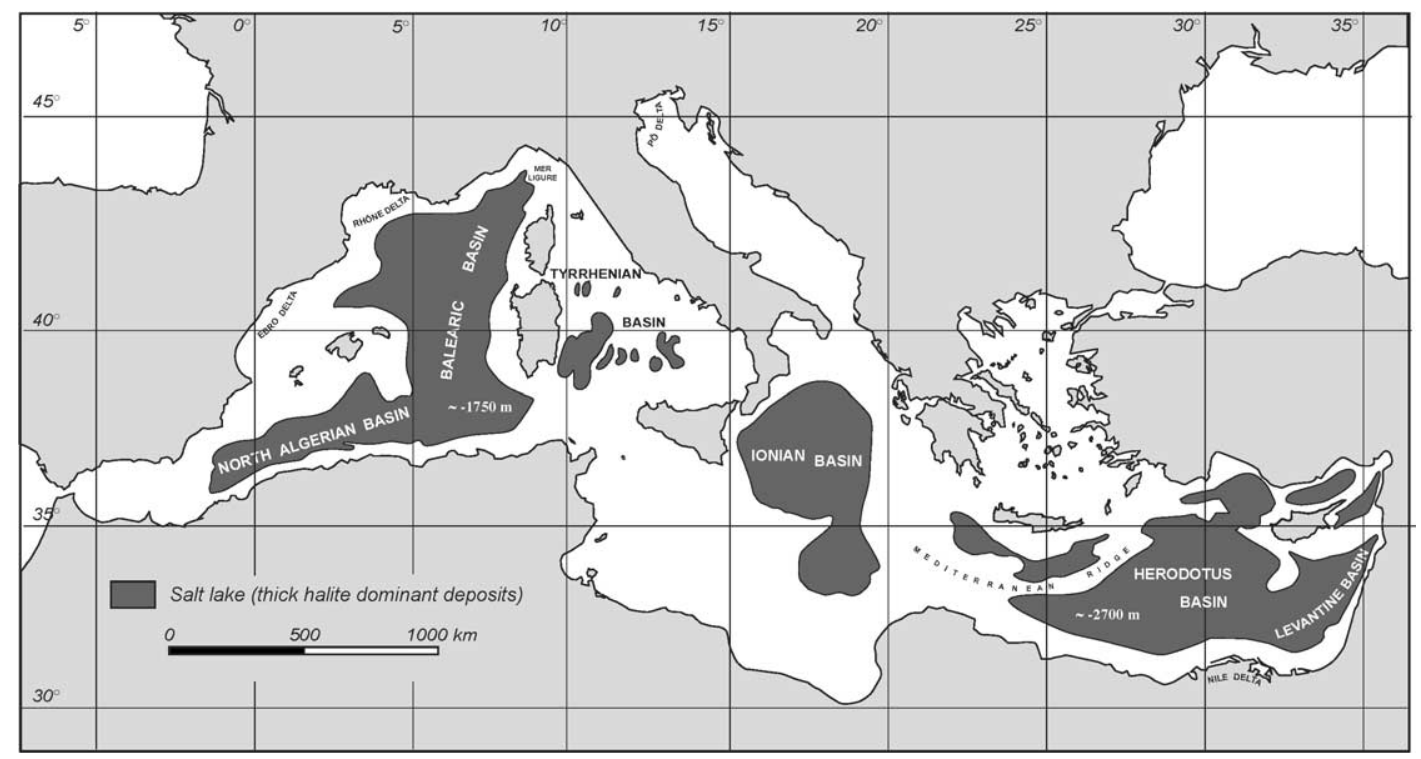

Fig. 69. Schematic paleogeographical map of the Mediterranean Basin during the Messinian drop of sea level, modified after Rouchy (1981).

- establishment of a major river, the "Eonile," west of the uplifted rift shoulders of the Red Sea-Gulf of Suez, during the Late Miocene (Said, 1981). This river cut a channel longer and deeper than that of the modern Grand Canyon in the Western US;

- the partial desiccation of the Mediterranean Sea during the Messinian (Fig. 69), that was briefly closed in response to the development of the Gibraltar Arc and the Syrian Arc as parts of the Alpine Belt, and synchronous minor drop in global sea level (Clauzon et al., 1996);

- the Early Pliocene transgression that invaded the deep Messinian paleo-valleys around the Mediterranean Basin, in particular in Egypt and Libya (Fig. 64).

Finally, we point out the occurrence of a post-early Pleistocene compressional event. Additionally, up to six levels of marine or continental terraces developed along some marine shorelines and fluvial valleys due to the interplay of tectonics and glacio-eustatic sea-level fluctuations. Along the fluvial basins, large coarse terrigenous, alluvial stepped terraces were preserved. According to the climate zonation, when moving from northernmost Africa towards the Congo Basin, the alluvium can be capped by calcretes, gypsum crusts, laterites, or silcretes. Landscapes vary accordingly.

\section{Summary and conclusions}

The preserved stratigraphic series permit reconstruction of the paleogeographic and tectonic history of Northern and Central Africa. We shall attempt to summarize this history, trying to show how it relates on a broader scale to the evolution of the African-Arabian cratonic domain and the southern margin of the Paleotethys and Neotethys oceans.

\subsection{Paleozoic}

During Paleozoic times, the main paleogeographic characteristics were the permanency of large exposed lands over central Africa, surrounded by northerly and northwesterly dipping pediplanes episodically flooded by epicontinental seas related to the Paleotethys s.l. Ocean (Fig. 1). The permanency southwards of the intra-continental Congo-Zaire Basin (Daly et al., 1992; Giresse, this issue) also must be noted, as well as the initiation eastwards of the Somali Basin (western Indian Ocean) from Late Carboniferous times, in conjunction with the development of the Karoo basins (Guiraud and Bellion, 1995). This configuration had a strong influence on facies distributions. Eustatic sea-level fluctuations, associated with global climatic changes, also affected sedimentation. The main transgressions occurred during the Early Cambrian, Tremadocian, Llandovery, Middle/Late Devonian, Early Carboniferous, and Moscovian.

This tectonic history shows an alternation of long periods of predominately gentle basin subsidence and short periods of gentle folding and, sometimes basin inversion. Some local rift basins episodically developed, mainly located along the northern African-Arabian plate margin and near the West African Craton/Pan-African Belt suture. Several arches or spurs, mainly N-S to NE-SW trending and inherited from late Pan-African fault swarms, played an important role (e.g., the Amguid Spur in southern Algeria or the Uweinat-Bahariya Arch in Egypt). The Nubia Province (northern Sudan-southern Egypt) was the site of numerous alkaline anorogenic intrusions, starting in Ordovician times, and subsequently formed a large swell.

Special attention must be given to brief folding events. They are associated with and provoked major regressions, particularly along arches that were uplifted at these times. In the basins, they contributed to the development of 
breaks in sedimentation and unconformities. Figs. 9 and 10 list these tectonic events and show their stratigraphic position. Significant events separate the different Paleozoic sequences, and resulted in major changes in the paleogeography and tectonic framework. They occurred by the latest Early Cambrian ("Iskelian"), the end Silurian ("Early Acadian" or "Ardennian"), the mid-Devonian ("MidAcadian"), the end Devonian ("Late Acadian" or "Bretonnian"), the earliest Serpukhovian ("Sudetic"), and the latest Carboniferous-earliest Permian ("Alleghanian" or "Asturian"). The most important deformation, including folding, thrusting, and active strike-slip faulting, affected Northwestern Africa in two periods: (1) by the end Early Cambrian, during the last stage of the Pan-African Belt development around the West African Craton, and (2) during the polyphased Hercynian-Variscan Orogeny which entailed the final closure of the Paleotethys Ocean and resulted here in the formation of the Maghrebian and Mauritanides belts. Only gentle deformation affected central and northeastern African during the Paleozoic, the latter remaining a passive margin of the Paleotethys Ocean up to the Early Permian when the development of the Neotethys initiated along the Eastern Mediterranean Basins.

\subsection{Mesozoic and Cenozoic}

The Mesozoic-Cenozoic sedimentary sequence consists of a succession of eustatically and tectonically controlled depositional cycles (Figs. 26, 27 and 70). Through time, progressive southwards shift of the basin margins, from the continental margin towards the epicontinental domain, can be observed. This is thought to be related to: (1) the opening of the Neotethys Ocean up to the Equatorial Atlantic, the Somali-Mozambique Basin, and the Gulf of Aden-Red Sea, and (2) the transgressions resulting from warming of the global climates and associated rise of the global sea levels. Some permanent or long-lived swells and arches, often active during the Paleozoic, such as the Guinean-Nigerian Shield, the Hoggar, Tibesti-Central Cyrenaica, Nubia, western Saudi Arabia, and Central African Republic arches, delimited the principal basins. However, the main tectonic features were: (1) polyphased extension, inversion, and folding of the northern AfricanArabian shelf margin resulting in the development of the Alpine Maghrebian and Syrian Arc belts, (2) rifting and drifting along the Central Atlantic, Somali Basins, and Gulf of Aden-Red Sea domains, and (3) rifting and partial inversion along the Central African Rift System. We summarize below the main steps in the Mesozoic-Cenozoic evolution of the large area under consideration.

The Triassic was characterized by tensional tectonic activity. All along the northernmost African-Arabian plate margin, $\sim \mathrm{E}-\mathrm{W}$ trending tilted blocks and rifts developed, from Morocco to the Palmyrides. The N-S striking Levant fault system acted as a transfer/transform fault zone, allowing the opening of the East Mediterranean Basin which registered strong thinning of the continental crust or even break-up (Stampfli and Borel, 2002). The tensional regime favored eruption of alkaline flow basalts (Wilson and Guiraud, 1998). Large rifts developed along the future Central Atlantic domain, from Morocco to the Demerara Plateau, and along or near the East African margin (Karoo basins). Warming in the climate during the Triassic resulted in the progression of epicontinental seas along the forming depressions and frequent sedimentation of evaporites. Numerous alkaline anorogenic complexes intruded the Nubia-central Sudan province. During the latest Triassic, gentle tectonic deformation took place.

During the Jurassic, rifting and block tilting first developed in the Liassic and then decreased or stopped, but in northeastern Africa-southwestern Arabia and northern Benue where tensional deformations initiated and continued. Drifting probably commenced from Dogger times in the Central Atlantic domain (Le Roy et al., 1998; Davison, this issue) and from Oxfordian times in the Somali Basin (Rabinowitz et al., 1983). A major global transgression occurred in the Early Kimmeridgian that resulted in the development of epicontinental seas over Arabia and eastern Africa, up to the Congo Basin (Cahen, 1983; Cecca et al., 1993). The Nubia alkaline magmatic province was active again during the Late Jurassic. Local basin inversion and folding occurred along the Moroccan Middle and High Atlas during the Middle Jurassic (Laville et al., 2004), probably associated with initiation of drifting along the Central Atlantic domain. Gentle compressional tectonic deformation took place around the Jurassic-Cretaceous transition. Increasing along the Levant domain, this deformation represents the distal effects of the "Cimmerian event" that affected the northwestern Arabian and southeastern European plates boundaries (Guiraud and Bosworth, 1999).

The Early Cretaceous registered the major stage in the break-up of western Gondwana, illustrated by the crustal separation of the African and South American plates by the latest Albian. Three blocks separated in Africa-Arabia (Guiraud and Maurin, 1991, 1992), in response to two successive active tensional episodes that occurred: (1) from Late Berriasian to earliest Aptian times, and (2) from Early Aptian to early Late Albian (Figs. 46 and 47). The Arabian-Nubian Block first moved northwards to northwestwards, and then northeastwards. In Central Africa, these episodes resulted in the polyphased development of the Central African Rift System extending from the Benue Trough (Nigeria) to the Anza Basin (Kenya) (Figs. 41A and 41B), characterized by the deposition of thick continental series under alternatively extensional and transtensional stress fields. The rejuvenation of intra-plate late Pan-African major fault zones favored rift development (Maurin and Guiraud, 1993). The northernmost AfricanArabian plate margin also registered rifting activity or block tilting, especially near the Levant fault zone that allowed transfer of movement and a new stage in the opening of the Eastern Mediterranean Basin. During 
Mid Carboniferous to Recent tectonic events along the African-Arabian Tethyan margin

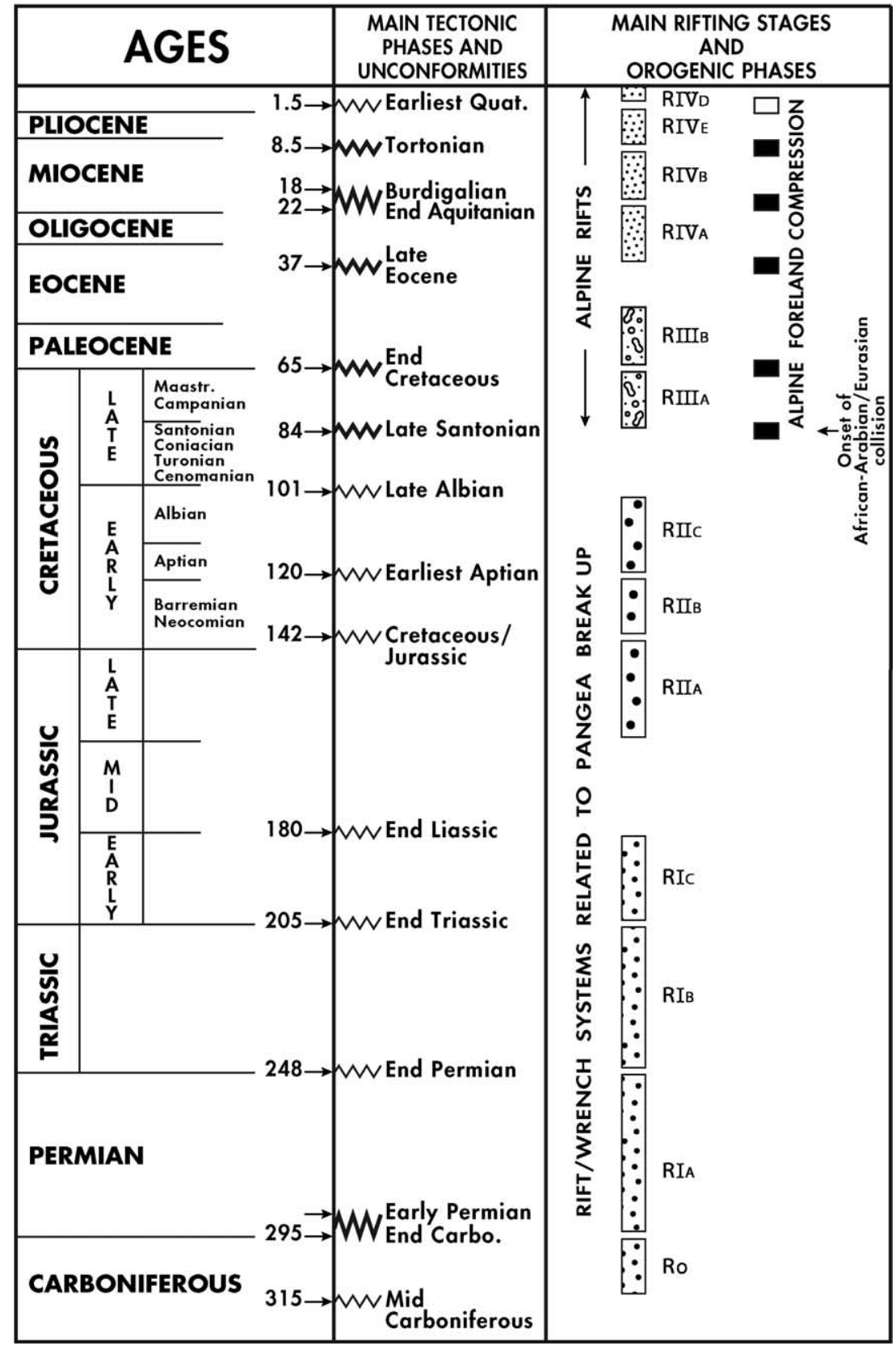

Fig. 70. Mid-Carboniferous to Recent tectonic events along the African-Arabian Tethyan margin, slightly modified after Guiraud (1997).

Neocomian-Barremian times, this Levant Province and the Nubia Province exhibited high levels of magmatic activity (Wilson and Guiraud, 1998). Short marine transgressions occurred in the mid-Late Aptian and the early Late Albian.

Major transgressions took place during Late Cenomanian to Lutetian times, briefly interrupted by regressions of tectono-eustatic origin. These high sea levels, associated with warm climates, favored the development of carbonate platforms along Northern and Central Africa, and Arabia (Dercourt et al., 1993, 2000). Rifting carried on during Cenomanian-Early Senonian times along some Ténéré-
Benue and Sudan troughs (Fig. 49A). This allowed the development of a large intra-continental seaway extending from southwestern Libya to the Gulf of Guinea-Equatorial Atlantic via the Benue Valley. However, the main feature is a change in the regional stress field that is reflected by the onset of basin inversion and/or folding during Late Santonian times, affecting both the $\sim \mathrm{E}-\mathrm{W}$ striking northern African-Arabian plate margin and central African rifts (Guiraud and Bosworth, 1997) (Fig. 51). These deformations are related to a compressive event, which corresponds to the first stage of the collision of the African-Arabian 
and Eurasian plates in response to changes in the opening directions and rates of the South, Central, and North Atlantic oceans (Binks and Fairhead, 1992; Fairhead et al., 2003). More generally, the Santonian event corresponds to a global event, underlined by its synchronism with the end of the "Cretaceous Normal Magnetic Quiet Zone" (Guiraud and Bosworth, 1997; Sager and Koppers, 2000). Following this event, a new stress field prevailed in Africa-Arabia, causing the further development of the large NW-SE to N-S trending intra-continental rifts of Sudan and Ténéré, and marginal rifts of northern Sirt, Azraq (Jordan) and the Euphrates (Fig. 49B). Tensional activity favored breccia and slump sedimentation, and magmatism.

A large $\mathrm{N}-\mathrm{S}$ trending epicontinental sea-arm invaded the West Africa platform, extending from southwestern Algeria to southern Niger. Also, noticeable was the development of lateritic-bauxite crusts over Central Africa and southern Western Africa. Around the end Cretaceous, a brief compressional pulse occurred during which most of the Santonian structures were amplified (Fig. 51). Tensional tectonics resumed during the Early Paleocene and carried on up to the end Early Paleocene. Noticeable also were brief transgressions that occurred during the Early Paleocene and resulted in the development of sea-arms around the Hoggar Massif and, possibly extending to the Gulf of Guinea via the middle Nigeria paleo-Niger valley (Fig. 57A).

By the end Bartonian-Early Priabonian a major platescale compressional event occurred (Fig. 58). This "Early Late Eocene event" was particularly strong along the northwestern African Maghrebian Margin where it corresponds to the so-called "Pyrenean-Atlasic" event (Guiraud, 1973; Guiraud and Bellion, 1995), responsible for basin inversion and folding along the Alpine foreland, and thrusting and metamorphism along the "Zones internes" units (Guiraud et al., 1987; Frizon de Lamotte et al., 2000). Folding and local thrusting then affected the "Syrian Arc" that developed from Cyrenaica to the Palmyrides (Guiraud and Bosworth, 1999; Bosworth et al., 1999). The $\sim \mathrm{E}-\mathrm{W}$ trending Central African Fold Belt also gently developed. Transpression occurred along the major intraplate fault zones. Stress field analysis shows a general NNW-SSE to N-S shortening, resulting from a new stage in the collision of the African-Arabian and Eurasian plates (Guiraud and Bellion, 1995).

This compressional phase was rapidly followed by dextral transpression along the African-Arabian/Eurasian plate boundaries and, in both domains, by the development of the NNW-SSE to NNE-SSW trending Oligocene rifts. In Africa-Arabia, the most active rifts developed along the Red Sea-Gulf of Aden Province (see Bosworth et al., this issue) and along the East African Lakes Province (see Chorowicz, this issue), which both registered active magmatism including voluminous intra-plate alkali basalts, tholeiitic to transitional dyke swarms, and plutons. This strong magmatic activity carried on until Recent times.
Several similar magmatic provinces more or less synchronously developed in northern Arabia, Central, Western and Northern Africa, amongst which the most important are the Cameroon Line, Darfur, Harudj, Tibesti, Hoggar, Cape Verde, and Canary provinces (reviewed in Wilson and Guiraud, 1998). The magmatic intrusions, resulting from hot spots or mantle plume development, entailed uplifts (Fig. 68) and consequently reductions in the size of the intra-continental sedimentary basins (Fig. 63A, 63B, 64). However, during the latest Eocene to Recent times, the area under consideration also experienced some eustatic and stress field changes. Of particular importance were the earliest Oligocene brief, global marine regression and the strong drop of the Mediterranean sea level during the Messinian, which resulted in the incision of deep canyons and the deposition of thick evaporate layers. Quaternary pluvial/interpluvial episodes also controlled major changes in depositional environments. Compressional episodes occurred during Early Miocene, Tortonian, and early Quaternary times, of particular importance in the northwestern Africa Maghrebian Alpine Belt that then underwent strong folding and thrusting of the Internal units (reviewed in Guiraud et al., 1987; Frizon de Lamotte et al., 2000). Recent tectonic activity is mainly concentrated along the Maghrebian Alpine Belt, the offshore Nile Delta, the Red Sea-East African Rifts Province, the Aqaba-Dead Sea-Bekaa sinistral strike-slip fault zone, and some major intra-plate fault zones, e.g., the Guinea-Nubia, Aswa, and central Sinai lineaments.

In conclusion, Northern, Western, Central and northeastern Africa, and Arabia, witnessed the opening and the closure of Paleotethys and Neotethys. The observed general northward, westward, and northeastward thickening of basins persisted through time as a consequence of the permanency of the Paleotethys and Neotethys margins, but also as a result of the repeated magmatic activity and uplift of the Nubia, Hoggar, and Jos-Cameroon provinces. This pattern was partly modified from Late Jurassic-earliest Cretaceous times, with the development of the Central African Rift System that resulted in the formation of large intra-plate depressions and thick sedimentary basins. The Phanerozoic tectonostratigraphic history of the overall large region as considered reflects an alternation of long periods of quiescence, subsidence, or rifting, separated by brief compressional events. For many aspects it exemplifies, on a broader scale, the history of the entire AfricanArabian plate.

\section{Acknowledgements}

We thank Kevin Burke, Bahay Issawi, and Peter Ziegler for many fruitful discussions regarding the geologic history of North and Central Africa. Magda Geringer and Louis Briqueu gave assistance with the drawing of some of the figures. Pat Eriksson, Adam Bumby, and Bernard Fourcade provided helpful reviews of the manuscript. Joe Brannan and Shell are warmly acknowledged for their generous 
financial support for colour printing of our paleogeological maps.

\section{References}

Abuhajar, M.I., Roohi, M., 2003. Giant fields in the Sirte Basin, Libya. In: 9th North African Oil and Gas Conference, October 2003, Tunis, ETAP, Extended Abstract, $25 \mathrm{p}$.

Aité, M.O., Gélard, J.P., 1997. Distension néogène post-collisionnelle sur la transect de Grande-Kabylie. Bull. Soc. géol. France 168, 423-436.

Aitt-Hamou, F., 2000. Un exemple de Point Chaud intra-continental en contexte de plaque quasi-stationnaire: étude pétrologique et géochimique du Djebel Taharq et évolution du volcanisme Cénozoïque de l'Ahaggar (Sahara Algérien). Thesis, University Montpellier II, France, $268 \mathrm{p}$.

Ali Kassim, M., Carmignani, L., Conti, P., Fantozzi, P.L., 2002. Geology of the Mesozoic-Tertiary sedimentary basins in southwestern Somalia. J. African Earth Sci. 34, 3-20.

Alsharan, A.S., Nairn, A.E.M., 1997. Sedimentary basins and petroleum geology of the Middle East. Elsevier, Amsterdam, 942 p.

Aris, Y., Coiffait, P.E., Guiraud, M., 1998. Characterization of MesozoicCenozoic deformations and paleostress fields in the Central Constantinois, northeast Algeria. Tectonophysics 290, 59-85.

Ball, E., 1980. An example of very consistent brittle deformation over a wide intracontinental area. The late Pan-African fracture system of the Tuareg and Nigerian shield. Tectonophysics 61, 363-379.

Bard, J.P., 1997. Démembrement ante-mésozoïque de la chaîne varisque d'Europe occidentale et d'Afrique du Nord: rôle essentiel des grands décrochements transpressifs dextres accompagnant la rotation-translation horaire de l'Afrique durant le Stéphanien. CR Acad. Sci. Paris 324, 693-704.

Basile, C., Mascle, J., Guiraud, R., this issue. Phanerozoic geological evolution of the Equatorial Atlantic domain. J. African Earth Sci., doi:10.1016/j.jafrearsci.2005.07.011.

Bellini, E., Massa, D., 1980. A stratigraphic contribution to the Paleozoic of the southern basins of Libya. In: Salem, M.J., Busrewil, M.T. (Eds.), The Geology of Libya, vol. 1. Academic Press, London, pp. 356.

Bellion, Y., 1989. Histoire géodynamique post-paléozoïque de l'Afrique de l'Ouest d'après l'étude de quelques bassins sédimentaires (Sénégal, Taoudenni, Iullemmeden, Tchad). CIFEG, Publ. Occasionnelles 17, 302

Bellion, Y., Guiraud, R., 1988. Déformations d'origine compressive d'âge intra-éocène à l'Ouest de l'Adrar des Iforas (Mali). CR Acad. Sci. Paris 307, 529-532.

Bellion, Y., Benkhelil, J., Guiraud, R., 1984. Mise en évidence de déformations d'origine compressive dans le Continental intercalaire de la partie méridionale du bassin de Taoudeni (Hodh oriental, confins mauritano-maliens). Bull. Soc. géol. France 6, 1137-1147.

Benkhelil, J., Mascle, J., Tricart, P., 1995. The Guinea continental margin: an example of a structurally complex transform margin. Tectonophysics 248, 117-137.

Bertrand-Sarfati, J., Moussine-Pouchkine, A., Amard, B., Ait Kaci Ahmed, A., 1995. First Ediacaran fauna found in western Africa and evidence for an Early Cambrian glaciation. Geology 23, 133-136.

Beuf, S., Biju-duval, B., de Charpal, O., Rognon, P., Gariel O., Bennacef, A., 1971. Les grès du Paléozoïque inférieur au Sahara. Sédimentation et discontinuité. Evolution structurale d'un craton. Ed. Technip, Paris, Coll. Sc. et Techn. du Pétrole, 480 p.

Binks, R.M., Fairhead, J.D., 1992. A plate tectonic framework for the evolution of the Cretaceous rift basins in West and Central Africa. In: Ziegler, P.A. (Ed.), Geodynamics of Rifting, vol. 2, Case History studies on Rifts: North and South America, Africa-Arabia. Tectonophysics, vol. 213, 141-151.

Boote, D.R.D., Clark-Lowes, D.D., Traut, M.W., 1998. Palaeozoic petroleum systems of North Africa. In: MacGregor, D.S., Moody,
R.T.J., Clark-Lowes, D.D. (Eds.), Petroleum Geology of North Africa. Geological Society, London, Special Publication 132, 7-68.

Bosellini, A., 1992. The continental margins of Somalia: structural evolution and sequence stratigraphy. American Association of Petroleum Geologists Memoir 53, 185-205.

Bosworth, W., 1992. Mesozoic and early Tertiary rift tectonics in East Africa. Tectonophysics 209, 115-137.

Bosworth, W., McClay, K., 2001. Structural and stratigraphic evolution of the Gulf of Suez rift, Egypt: A synthesis: In: Ziegler, P.A., Cavazza, W., Robertson, A.H.F., Crasquin-Soleau, S. (Eds.), Peri-Tethys Memoir 6: Peri-Tethyan Rift/Wrench Basins and Passive Margins. Mémoires du Muséum national d'Histoire naturelle de Paris 186, pp. 567-606.

Bosworth, W., Guiraud, R., Kessler, L.G., 1999. Late Cretaceous $( \pm 84 \mathrm{Ma})$ compressive deformation of the stable shelf of NE Africa (Egypt): far-field stress effects of the "Santonian event" and origin of the Syrian arc. Geology 27, 633-636.

Bosworth, W., Huchon, P., McClay, K., Abbatte, E., this issue. The Red Sea and Gulf of Aden Basins. J. African Earth Sci., doi:10.1016/ j.jafrearsci.2005.07.020.

Bouaziz, S., Barrier, E., Soussi, M., Turki, M.M., Zouari, H., 2002. Tectonic evolution of the northern African margin in Tunisia from paleostress data and sedimentary record. Tectonophysics 357, 227 253.

Boudjema, A., 1987. Evolution structurale du basin pétrolier "triasique" du Sahara nord oriental (Algérie). Thesis, University Paris-Sud, $290 \mathrm{p}$.

Bracène, R., Frizon de Lamotte, D., 2002. The origin of intraplate deformation in the Atlas system of western and central Algeria: from Jurassic rifting to Cenozoic-Quaternary inversion. Tectonophysics 357, 207-226.

Browne, S.E., Fairhead, J.D., 1983. Gravity study of the Central African Rift System: a model of continental disruption. 1. The Ngaoundere and Abu Gabra Rifts. Tectonophysics 94, 187-203.

Burke, K., MacGregor, D.S., Cameron, N.R., 2003. Africa's petroleum systems: four tectonic 'Aces' in the past 600 million years. Geological Society, London, Special Publication 207, 21-60.

Busson, G., 1972. Principes, méthodes et résultats d'une étude stratigraphique du Mésozoïque saharien. Mémoires du Muséum national d'Histoire naturelle, Nouv. Sér. 26, 441 p.

Caby, R., 1989. Precambrian terranes of Benin Nigeria and Northeast Brazil and the Late Proterozoic South Atlantic fit. Geological Society of America Special Paper, vol. 320, pp. 145-158.

Caby, R., 2003. Terrane assembly and geodynamic evolution of centralwestern Hoggar: a synthesis. J. African Earth Sci. 37, 133-159.

Cahen, L., 1983. Le Groupe de Stanleyville (Jurassique supérieur et Wealdien de l'intérieur de la République du Zaïre). Révision des connaissances. Mus. Roy. Afr. Centr., Tervuren (Belg.), Dépt. Géol. Min., Rapp. ann. 1981-1982, pp. 73-91.

Carr, I.D., 2002. Second-order sequence stratigraphy of the Palaeozoic of North Africa. J. Petrol. Geol. 25, 259-280.

Cattanéo, G., Gélard, J.-P., Aïté, M.O., Mouterde, R., 1999. La marge septentrionale de la Téthys maghrébine au Jurassique (Djurdjura et Chellata, Grande Kabylie, Algérie). Bull. Soc. géol. France 170, 173 188.

Cecca, F., Azéma, J., Fourcade, E., Baudin, F., Guiraud, R., Bonneau, M., De Wever, P. 1993. Early Kimmeridgian Palaeoenvironments (146-144 Ma). In: Dercourt, J., Ricou, L.E., Vrielynck, B. (Eds.), Atlas Tethys Palaeoenvironmental maps. Beicip-Franlab, Rueil-Malmaison.

Chalouan, A., Michard, A., 2004. The Alpine Rif Belt (Morocco): a case of mountain building in a subduction-subduction-transform fault triple junction. Pure Appl. Geophys. 161, 489-519.

Chorowicz, J., this issue. The East African Rift Basins. J. African Earth Sci., doi:10.1016/j.jafrearsci.2005.07.019.

Clauzon, G., Suc, J.-P., Gautier, R., Berger, A., Loutre, M.-F., 1996. Alternate interpretation of the Messinian salinity crisis: controversy resolved. Geology 24, 363-366. 
Conrad, J., 1984. Les séries carbonifères du Sahara central Algérien. Stratigraphie, sédimentation, évolution structurale. Thesis Sci., University Marseille 3, France, $370 \mathrm{p}$.

Cornacchia, M., Dars, R., 1983. Un trait structural majeur du continent africain. Les linéaments centrafricains du Cameroun au golfe d'Aden. Bull. Soc. géol. France 1, 101-109.

Courel, L., Ait Salem, H., Ben Ismaïl, H., El Mostaïne, M., Fekirine, B., Kamoun, F., Mami, L., Oujidi, M., Soussi, M., 2000. An overview of the epicontinental Triassic series of the Maghreb (NW Africa). Zbl. Geol. Paläontol. I 9-10, 1145-1166.

Courel, L., Aït Salem, H., Benaouiss, N., Et-Touhami, M., Fekirine, B., Oujidi, M., Soussi, M., Tourani, A., 2003. Mid-Triassic to Early Liassic clastic/evaporitic deposits over the Maghreb Platform. Palaeogeogr. Palaeoclimatol. Palaeoecol. 196, 157-176.

Coward, M.P., Ries, A.C., 2003. Tectonic development of North African basins. Geological Society, London, Special Publication 207, 61-83.

Crossley, R., McDougall, N., 1998. Lower Palaeozoic reservoirs of North Africa. In: MacGregor, D.S., Moody, R.T.J., Clark-Lowes, D.D (Eds.), Petroleum Geology of North Africa, Special Publication Geological Society (London), vol. 132, pp. 157-166.

Daly, M.C., Lawrence, S.R., Diemu-Tshiband, K., Matouana, B., 1992. Tectonic evolution of Cuvette Centrale, Zaire. J. Geol. Soc., London $149,539-546$

Davidson, L., Beswetherick, S., Craig, J., Eales, M., Fisher, A., Himmali, A., Jho, J., Mejrab, B., Smart, J., 2000. The structure, stratigraphy and petroleum geology of the Murzuq Basin, southwest Libya. In: Sola, M.A., Worsley, D. (Eds.), Geological Exploration in Murzuq Basin. Elsevier Science, Amsterdam, pp. 295-320, Chapter 14

Davison, I., this issue. The Central Atlantic continental margin basins of Africa. J. African Earth Sci., doi:10.1016/j.jafrearsci.2005.07.018.

Delfaud, J., 1974. Les grands traits de la paléogéographie de l'Algérie septentrionale durant le Jurassique supérieur et le Crétacé inférieur. CR somm. Soc. géol. France 6, 167-168.

Dercourt, J., Ricou, L.E., Vrielynck, B. (Eds.), 1993. Atlas Tethys, Palaeoenvironmental Maps. Gauthier-Villars, Paris, 307 p, 14 maps, 1 pl.

Dercourt, J., Gaetani, M., Vrielynck, B., Barrier, E., Biju-Duval, B., Brunet, M.F., Cadet, J.P., Crasquin, S., Sandulescu, M. (Eds.), 2000. Atlas Peri-Tethys, Palaeogeographical maps. CCGM/CCMW, Paris, 24 maps and explanatory notes, I-XX, 269 p.

Destombes, J., Hollard, H., Willefert, S., 1985. Lower Paleozoic rocks of Morocco. In: Holland, C. (Ed.), Lower Paleozoic Rocks of Northwestern and Western Africa. Wiley \& Sons, New York, pp. 91-336.

Deynoux, M., 1983. Les formations de plate-forme d'âge Précambrien Supérieur et Paléozö̈que dans l'Ouest Africain, corrélation avec les zones mobiles. In: Fabre, J. (Ed.), Afrique de l'Ouest. Pergamon, Oxford, pp. 46-74.

Deynoux, M., Sougy, J., Trompette, R., 1985. Lower Paleozoic rocks of West Africa and the western parts of central Africa. In: Holland, C. (Ed.), Lower Paleozoic Rocks of Northwestern and Western Africa. Wiley \& Sons, New York, pp. 337-495.

Ebinger, C.J., Yemane, T., WoldeGabriel, G., Aronson, J.L., Walter, R.C., 1993. Late Eocene-Recent volcanism and faulting in the southern main Ethiopian Rift. J. Geol. Soc., London 150, 99-108.

Echikh, K., Sola, M.A., 2000. Geology and hydrocarbon occurrences in the Murzuq Basin, SW Libya. In: Sola, M.A., Worsley, D. (Eds.), Geological Exploration in Murzuq Basin. Elsevier Science, Amsterdam, pp. 175-222.

El Harfi, A., Lang, J., Salomon, J., Chellai, E.H., 2001. Cenozoic sedimentary dynamics of the Ouarzazate foreland basin (Central High Atlas Mountains, Morocco). Int. J. Earth Sci. (Geol. Rundsch.) 90, 393-411.

Ellis, A.C., Kerr, H.M., Cornwall, C.P., Williams, D.O, 1996. A tectonostratigraphic framework for Yemen and its implication for hydrocarbon potential. Petrol. Geosci. 2, 29-42.

Ellouz, N., Patriat, M., Gaulier, J.-M., Bouatmani, R., Sabounji, S., 2003. From rifting to Alpine inversion: Mesozoic and Cenozoic subsidence history of some Moroccan basins. Sediment. Geol. 156, 185-212.
Elmi, S., Alméras, V., Ameur, M., Bassoulet, J.-P., Boutakiout, M., Benhamou, M., Marok, A., Mekahli, L., Mekkaoui, A., Mouterde, R., 1998. Stratigraphic and palaeogeographic survey of the Lower and Middle Jurassic along a north-south transect in western Algeria. In: Crasquin-Soleau, S., Barrier, E. (Eds.), Peri-Tethys Memoir 4, Epicratonic basins of Peri-Tethyan platforms, Mémoires du Muséum national d'Histoire naturelle de Paris 179, pp. 145-211.

Fabre, J., 1976. Introduction à la géologie du Sahara algérien et de régions voisines. I: La couverture phanérozoïque. Société nationale d'édition et de diffusion, Algiers, $421 \mathrm{p}$.

Fabre, J., 1988. Les séries paléozoïques d'Afrique: une approche. J. African Earth Sci. 7, 1-40.

Fairhead, J.D., 1988. Mesozoic plate tectonic reconstructions of the central South Atlantic Ocean: the role of the West and Central African rift system. Tectonophysics 155, 181-191.

Fairhead, J.D., Guiraud, R., Stone, V., 2003. Mesozoic Plate Tectonic controls on Rift Basin Development on North Central Africa: a major Cretaceous Basin Systems. AAPG Annual Meeting 2003: Energy-Our Monumental Task, Salt Lake City 12-14 April, Abstract, 4 p.

Fantozzi, P.L., Ali Kassim, M., 2002. Geological mapping in northeastern Somalia (Midjiurtinia region): field evidence of the structural and paleographic evolution of the northern margin of the Somalian plate. J. African Earth Sci. 34, 21-55.

Fantozzi, P.L., Sgavetti, M., 1998. Tectonic and sedimentary evolution of the eastern Gulf of Aden continental margins: new structural and stratigraphic data from Somalia and Yemen. In: Purser, B.H., Bosence, D.W.J. (Eds.), Sedimentation and Tectonics of Rift Basins: Red Sea-Gulf of Aden. Chapman and Hall, London, pp. 56-76.

Faure, H., 1966. Reconnaissance géologique des formations sédimentaires post-paléozoïques du Niger oriental. Publ. Dir. Mines et Géol., Rép. Niger, 1, B.R.G.M., Paris (Ed.), 630 p.

Fidalgo Gonzáles, L., 2001. La cinématique de l'Atlantique Nord: la question de la déformation intraplaque. Thesis, University Brest 2, France, $260 \mathrm{p}$.

Fiechtner, L., Friedrichsen, H., Hammerschmidt, K., 1992. Geochemistry and geochronology of Early Mesozoic tholeiites from Central Morocco. Geol. Rundsch. 81, 45-62.

Frizon de Lamotte, D., Saint Bezar, B., Bracène, R., Mercier, E., 2000. The two main steps of the Atlas building and geodynamics of the western Mediterranean. Tectonics 19, 740-761.

Galeazzi, S., Haddadi, N., Blanpied, C., Rubino, J.L., Ousset, E., 2001. Lower Paleozoic depositional cycles of the Berkine and Illizi basins of the Algerian Saharan Platform: their development in the paleo-Tethys Gondwana continental margin. Séminaire de Géologie pétrolière, SGP 4 -Sonatrach, Algiers, November 2000, pdf, 23 p.

Genik, G.J., 1992. Regional framework, structural and petroleum aspects of rift basins in Niger, Chad and the Central African Republic (C.A.R.). Tectonophysics 213, 169-185.

Genik, G.J., 1993. Petroleum geology of Cretaceous-Tertiary rift basins in Niger, Chad and Central African Republic. Bull. Amer. Assoc. Petrol. Geol. 77, 1405-1434.

Geological Survey of Egypt, 1981. Geological map of Egypt, scale $1: 2,000,000$.

Ghienne, J.F., Deynoux, M., 1998. Large-scale channel fill structures in Late Ordovician glacial deposits in Mauritania, western Sahara. Sediment. Geol. 119, 141-159.

Giresse, P., this issue. The Mesozoic-Cenozoic interior sag basins of central Africa: Congo. J. African Earth Sci., doi:10.1016/ j.jafrearsci.2005.07.009.

Gradstein, F.M., Ogg, J.G., 1996. A Phanerozoic time scale. Episodes 19, $3-4$

Gradstein, F.M., Agterberg, F.P., Ogg, J.G., Hardenbol, J., Van Veen, P., Theirry, J., Huang, Z., 1995. A Triassic, Jurassic and Cretaceous time scale. In: Geochronology, Time Scales and Global Stratigraphic Correlations, SEPM (Society for Sedimentary Geology), Special Publication 54, pp. 95-126.

Gravelle, M., 1969. Recherches sur la géologie du sole précambrien de l'Ahaggar centro-occidental dans la région Silet-Tibéhaouine. 
Contribution à la reconnaissance géochronologique, géochimique et structurale des terrains cristallins du Sahara central. Mém. Centre Géologique Géophysique 21, CNRS Paris, 781 p.

Greigert, J., Pougnet, R., 1967. Essai de description des formations géologiques de la République du Niger. Publ. Dir. Mines et Géol., Rép. Niger, 3, B.R.G.M. (Ed.), 238 p.

Guardia, P., 1975. Géodynamique de la marge alpine du continent africain d'après l'étude de l'Oranie nord-occidentale. Relations structurales et paléogéographiques entre le Rif externe, le Tell et l'avant-pays atlasique. Thesis Sci., Nice, France, 289 p.

Guiraud, M., 1993. Late Jurassic rifting-Early Cretaceous rifting and Late Creaceous transpressional inversion in the upper Benue Basin (NE Nigeria). Bull. Centres Rech. Explor.-Prod. Elf Aquitaine 17, 371383.

Guiraud, R., 1973. Evolution post-triasique de l'avant pays de la chaîne alpine en Algérie, d'après l'étude du bassin du Hodna et des régions voisines. Thesis Sci., University Nice, France, 270 p.

Guiraud, R., 1975. L'évolution post-triasique de l'avant-pays de la chaîne alpine en Algérie, d'après l'étude du bassin du Hodna et des régions voisines. Rev. Géogr. phys. et Géol. dyn. 17 (2), 427-446.

Guiraud, R., 1978. Le 'Continental terminal' en Algérie. Ann. Fac. Sc. Dakar 31, 85-87.

Guiraud, R., 1986. Corrélations entre les principaux événements géodynamiques enregistrés du Trias à nos jours sur les marges alpine et atlantique de la plaque africaine. In: 5th Conf. PICG-UNESCO 183, Rev. Fac. Sci. Marrakech, Section Sciences de la Terre, $\mathrm{N}^{\circ}$ Special 2, pp. 313-338.

Guiraud, R., 1990. Evolution post-triasique de l'avant-pays de la chaîne alpine en Algérie, d'après l'étude du bassin du Hodna et des régions voisines. Mémoire 3, Service Géologique de l'Algérie, Algiers, $271 \mathrm{p}$.

Guiraud, R., 1997. The main Mesozoic-Cenozoic tectonic phases along the African-Arabian Tethyan margin: an overview. IGCP 369 Annual Meeting, Barcelona, August 1997, Abstracts vol., pp. 4142.

Guiraud, R., 1998. Mesozoic rifting and basin inversion along the northern African Tethyan margin: an overview. In: MacGregor, D.S., Moody, R.T.J., Clark-Lowes, D.D. (Eds.), Petroleum Geology of North Africa. Geological Society, London, Special Publication 133, pp. 217-229.

Guiraud, R., 2001. Northern Africa. In: Stampfli, G., Borel, G., Cavazza, W., Mosar, J., Ziegler, P.A. (Eds.), The Paleotectonic Atlas of the PeriTethyan Domain. European Geophysical Society.

Guiraud, R., Alidou, S., 1981. La faille de Kandi (Bénin), témoin du rejeu fini-crétacé d'un accident majeur à l'échelle de la plaque africaine. CR Acad. Sci. Paris 293, 779-782.

Guiraud, R., Bellion, Y., 1995. Late Carboniferous to Recent geodynamic evolution of the West Gondwanian cratonic Tethyan margins. In: Nairn, A., Ricou, L.E., Vrielynck, B., Dercourt, J. (Eds.), The Ocean Basins and Margins 8, the Tethys Ocean. Plenum Press, New York, pp. $101-124$.

Guiraud, R., Bosworth, W., 1997. Senonian basin inversion and rejuvenation of rifting in Africa and Arabia: synthesis and implications to plate-scale tectonics. Tectonophysics 282, 39-82.

Guiraud, R., Bosworth, W., 1999. Phanerozoic geodynamic evolution of northeastern Africa and the northwestern Arabian platform. Tectonophysics $315,73-108$.

Guiraud, R., Maurin, J.C., 1991. Le rifting en Afrique au Crétacé inférieur: synthèse structurale, mise en évidence de deux étapes dans la genèse des bassins, relations avec les ouvertures océaniques périafricaines. Bull. Soc. géol. France 162, 811-823.

Guiraud, R., Maurin, J.C., 1992. Early Cretaceous Rifts of Western and Central Africa. An overview. Tectonophysics 213, 153-168.

Guiraud, R., Issawi, B., Bellion, Y., 1985. Les linéaments guinéo-nubiens: un trait structural majeur à l'échelle de la plaque africaine. CR Acad. Sci. Paris 300, 17-20.

Guiraud, R., Bellion, Y., Benkhelil, J, Moreau, C., 1987. Post-Hercynian tectonics in Northern and Western Africa. In: Bowden, P., Kinnaird,
J.A. (Eds.), African Geology Reviews. Geological Journal 22, 433466.

Guiraud, R., Binks, R.M., Fairhead, J.D., Wilson, M., 1992. Chronology and geodynamic setting of Cretaceous - Cenozoic rifting in West and Central Africa. Tectonophysics 213, 227-234.

Guiraud, R., Doumnang Mbaigane, J.C., Carretier, S., Dominguez, S., 2000. New evidence for a $6000 \mathrm{~km}$ length NW-SE-striking lineament in northern Africa: the Tibesti Lineament. J. Geol. Soc. (London) 157, 897-900.

Guiraud, R., Issawi, B., Bosworth, W., 2001. Phanerozic history of Egypt and surrounding areas. In: Ziegler, P.A., Cavazza, W., Robertson, A.H.F., Crasquin-Soleau, S. (Eds.), Peri-Tethys Memoir 6: PeriTethyan Rift/Wrench Basins and Passive Margins. Mémoires du Muséum national d'Histoire naturelle de Paris 186, pp. 469509.

Haddoum, H., Guiraud, R., Moussine-Pouchkine, A., 2001. Hercynian compressional deformations of the Ahnet-Mouydir Basin, Algerian Saharan Platform: far-field stress effects of the Late Palaeozoic orogeny. Terra Nova 13, 220-226.

Hälbich, I.W., Fitch, F.J., Miller, J.A., 1983. Dating the Cape Orogeny. In: Söhnge, A.P.G., Hälbich, I.W. (Eds.), Geodynamics of the Cape Fold Belt, Geol. Soc. South Africa Special Publication 12, pp. 149164.

Hallett, D., 2002. Petroleum Geology of Libya. Elsevier Science B.V., Amsterdam, $503 \mathrm{p}$

Hirsch, F., 1990. Aperçu de l'histoire phanérozoïque d'Israël. J. African Earth Sci. 11, 177-196.

Hoepffner, C., Piqué, A., Soulaimani, A., 2005. Moroccan Hercynides and associated sedimentation. J. African Earth Sci., this issue, doi:10.1016/j.jafrearsci.2005.09.002.

Höhndorf, A., Meinhold, K.D., Vail, J.R., 1994. Geochronology of anorogenic igneous complexes in the Sudan: isotopic investigations in North Kordofan, the Nubian Desert and the Red Sea Hills. J. African Earth Sci. 19, 3-15.

Houari, M.-R., Hoepffner, C., 2003. Late Carboniferous dextral wrenchdominated transpression along the North African craton margin (Eastern High-Atlas, Morocco). J. African Earth Sci. 37, 1124.

Issawi, B., 1973. Nubia Sandstone: type section. Bull. Amer. Assoc. Petrol. Geol. 57, 741-745.

Janssen, M.E., 1996. Intraplate deformation in Africa as a consequence of plate boundary changes. Inferences from subsidence analysis and tectonic modelling of the Early and Middle Cretaceous period. Ph.D. Thesis, Free University Amsterdam, Holland, $161 \mathrm{p}$.

Keegan, J.B., Rasul, S.M., Shaheen, Y., 1990. Palynostratigraphy of the lower Paleozoic, Cambrian to Silurian of the Hashemite Kingdom of Jordan. Rev. Palaeobot. Palynol. 66, 167-180.

Keeley, M.L., 1994. Phanaerozoic evolution of the basins of Northern Egypt and adjacent areas. Geol. Rundsch. 83, 728-742.

Keeley, M.L., Wallis, R.J., 1991. The Jurassic System in northern Egypt: II. Depositional and tectonic regimes. J. Petrol. Geol. 14, 49-64.

Keeley, M.L., Dungworth, G., Floyd, C.S., Forbes, G.A., King, C., McGarva, R.M., Shaw, D., 1990. The Jurassic System in northern Egypt: I. Regional stratigraphy and implications for hydrocarbon prospectivity. J. Petrol. Geol. 13, 397-420.

Kilian, C.A., 1931. Des principaux complexes continentaux du Sahara. CR somm. Soc. géol. France, 109-111.

Klitgord, K.D., Schouten, H., 1986. Plate kinematics of the Central Atlantic. In: Tucholke, B.E., Vogt, P.P. (Eds.), The Western Atlantic Region (The Geology of North America, M.). Geological Society of America, pp. 351-378.

Klitzsch, E., 1963. Geology of the Northeast Flank of the Murzuk Basin (Djebel Ben Ghnema-Dor El Gussa Area). Rev. l'Inst. Français Pétrol. 18, 1411-1427.

Klitzsch, E., 2000. The structural development of the Murzuq and Kufra basins - significance for oil and mineral exploration. In: Sola, M.A., Worsley, D. (Eds.), Geological Exploration in Murzuq Basin. Elsevier Science, Amsterdam, pp. 143-149, Chapter 7. 
Konate, M., Guiraud, M., Lang, J., Yahaya, M., 2003. Sedimentation in the Kandi extensional basin (Benin and Niger): fluvial and marine deposits related to the Late Ordovician deglaciation in West Africa. J. African Earth Sci. 36, 185-206.

Lang, J., Kogbe, C.A., Alidou, S., Alzouma, K.A., Bellion, Y., Dubois, D., Durand, A., Guiraud, R., Houessou, A., Klasz, I. de, Roman, E., Salard-Cheboldaeff, M., Trichet, J., 1990. The Continental terminal in West Africa. In: Kogbe, C.A., Lang, J. (Eds.), African Continental Phanerozoic Sediments. J. African Earth Sci. 10, 79-99.

Lapierre, H., Mangold, C., Elmi, S., Brouxel, M., 1984. Deux successions volcano-sédimentaires dans le 'Trias' d'Oranie (Algérie occidentale); témoins de la fracturation d'une plate-forme continentale. Rev. Géol. dynam. Géogr. phys. 25, 361-373.

Laville, E., Zayane, R., Honnorez, J., Piqué, A., 1994. Le métamorphisme jurassique du Haut Atlas central (Maroc); épisodes synschisteux et hydrothermaux. CR Acad. Sci. Paris 318, 1256-1349.

Laville, E., Piqué, A., Amrhar, M., Charroud, M., 2004. A restatement of the Mesozoic Atlasic Rifting (Morocco). J. African Earth Sci. 38, 145153.

Léchorché, J.P., Bronner, G., Dallmeyer, R.D., Rocci, G., Roussel, J., 1991. The Mauritanide orogen and its northern extensions (Western Sahara and Zemmour), West Africa. In: Dallmeyer, R.D., Léchorché, J.P. (Eds.), The West African Orogens and Circum-Atlantic Correlatives. Springer-Verlag, Berlin, pp. 187-227.

Lefranc, J.P., Guiraud, R., 1990. The Continental intercalaire of Northwestern Sahara and its equivalents in the neighbouring regions. In: Kogbe, C.A., Lang, J. (Eds.), African continental Phanerozoic sediments. J. African Earth Sci. 10, 27-77.

Le Nindre, Y.-M., Vaslet, D., Le Métour, J., Bertrand, J., Halawani, M., 2003. Subsidence modelling of the Arabian Platform from Permian to Paleogene outcrops. Sediment. Geol. 156, 263-285.

Le Roy, P., Guillocheau, F., Piqué, A., Morabet, A.M., 1998. Subsidence of the Atlantic Moroccan margin during the Mesozoic. Canadian Journal of Earth Sciences 35, 476-493.

Letouzey, J., Trémolières, P., 1980. Paleo-stress fields around the Mediterranean since the Mesozoic derived from microtectonics: comparisons with plate tectonic data. In: Aubouin, J., Debelmas, J., Latreille, M. (Eds.), Geology of the Alpine chains born of the Tethys, Mém. B.R.G.M. 115, pp. 261-273.

Lovelock, P.E.R., 1984. A review of the tectonics of the northern Middle East region. Geol. Mag. 121, 577-587.

Lüning, S., Craig, J., Fitches, B., Mayouf, J., Busrewil, A., Ed Dieb, M., Gammudi, A., Loydell, D.K., 2000. Petroleum source and reservoir rock re-evaluation in the Kufra Basin (SE Libya, NE Chad, NW Sudan). In: Sola, M.A., Worsley, D. (Eds.), Geological Exploration in Murzuq Basin. Elsevier Science, London, pp. 151-174, Chapter 8.

Maluski, H., Coulon, C., Popoff, M., Baudin, P., 1995. ${ }^{40} \mathrm{Ar} /{ }^{39} \mathrm{Ar}$ chronology, petrology and geodynamic setting of Mesozoic to early Cenozoic magmatism from the Benue Trough, Nigeria. J. Geol. Soc., London 152, 311-326.

Mascle, J., Blarez, E., Marhino, M., 1988. The shallow structure of the Guinea and Ivory Coast-Ghana transform margins: their bearing on the Equatorial Atlantic Mesozoic evolution. Tectonophysics 155, 193 209.

Massa, D., 1988. Paléozoïque de Libye occidentale: stratigraphie et paléogéographie. Thesis Sci., University Nice, France, 514 p.

Masse, J.P., Bellion, Y., Benkhelil, J., Boulin, J., Cornée, J.J., Dercourt, J., Guiraud, R., Mascle, G., Poisson, A., Ricou, L.E., Sandulescu, M., 1993. Lower Aptian (114 to $112 \mathrm{Ma}$ ). In: Dercourt, J., Ricou, L.E., Vrielynck, B. (Eds.), Atlas Tethys Palaeoenvironmental Maps, Maps, BEICIP-FRANLAB, Rueil-Malmaison.

Matte, P., 2001. The Variscan collage and orogeny (480-290 Ma) and the tectonic definition of the Armorica microplate: a review. Terra Nova $13,122-128$

Mauffret, A., Maldonado, A., Campillo, A.C., 1992. Tectonic framework of the Eastern Alboran and Western Algerian Basins, Western Mediterranean. Geo-Marine Lett. 12, 104-110.
Mauffret, A., Frizon de Lamotte, D., Lallemant, S., Gorini, C., Maillard, A., 2004. East-west opening of the Algerian Basin (Western Mediterranean). Terra Nova 16, 257-264.

Maurin, J.C., Guiraud, R., 1990. Relationships between tectonics and sedimentation in the Barremo-Aptian intracontinental basins of Northern Cameroon. In: Kogbe, C.A., Lang, J. (Eds.), African continental Phanerozoic sediments. J. African Earth Sci. 10, 331-340.

Maurin, J.C., Guiraud, R., 1993. Basement control in the development of the Early Cretaceous West and Central African Rift System. Tectonophysics $228,81-95$.

Mbede, E.I., 1987. A review of the hydrocarbon potential of Kenya. J. African Earth Sci. 6, 313-322.

McHargue, T., Heidrick, T., Livingston, J., 1992. Tectonostratigraphic development of the Interior Sudan Rifts, Central Africa. Tectonophysics 213, 187-202.

Merabet, N., Henry, B., Yelles, A., Derder, M.M., 1990. Nouveaux pôles paléomagnétiques Carbonifère supérieur-Permien inférieur dans le craton stable saharien (Bassin d'Illizi, Algérie). CR Acad. Sci. Paris 311, 1499-1504.

Mohamed, A.Y., Pearson, M.J., Ashcroft, W.A., Whiteman, 2002. Petroleum maturation modeling, Abu Gabra-Sharaf area, Muglad Basin, Sudan. J. African Earth Sci. 35, 331-344

Moussa, Y., 1992. Dynamique sédimentaire du Guezouman et des formations viséennes sous-jacentes en liaison avec la tectonique, le volcanisme et le climat. Thesis University Bourgogne, Dijon, France, 355 p.

Nikishin, A.M., Ziegler, P.A., Panov, D.I., Nazarevich,k B.P., Brunet, M.-F., Stephenson, R.A., Bolotov, S.N., Korotaev, M.V., Tikhomirov, P.L., 2001. Mesozoic and Cainozoic evolution of the Scythian Platform-Black Sea-Caucasus domain. In: P.A. Ziegler, W. Cavazza, A.H.F. Robertson, S. Crasquin-Soleau (Eds.), Peri-Tethys Memoir 6: Peri-Tethyan Rift/Wrench Basins and Passive Margins, Mémoires du Muséum National d'Histoire Naturelle de Paris 186, pp. 295-346.

Olivet, J.L., Bonnin, J., Beuzart, P., Auzende, J.M., 1984. Cinématique de l'Atlantique nord et central. Rapports scientifiques et techniques du Centre national pour l'exploitation des océans 54, $108 \mathrm{p}$.

Paquette, J.L., Caby, R., Djoudi, M.T., Bouchez, J.L., 1998. U-Pb dating of the end of the Pan-African orogeny in the Tuareg shield: the postcollisional syn-shear Tioueine pluton (Western Hoggar, Algeria). Lithos 45, 245-253

Philip, J., 2003. Peri-Tethyan neritic carbonate areas: distribution through time and driving factors. Palaeogeogr. Palaeoclimatol. Palaeoecol. 196, 19-37.

Philip, J., Babinot, J.F., Tronchetti, G., Fourcade, E., Azéma, J., Guiraud, R., Bellion, Y., Ricou, L.E., Vrielynck, B., Boulin, J., Cornée, J.J., Herbin, J.P., 1993a. Late Cenomanian (94-92 Ma). In: Dercourt, J., Ricou, L.E., Vrielynck, B. (Eds.), Atlas Tethys Palaeoenvironmental Maps, Maps, BEICIP-FRANLAB, Rueil-Malmaison.

Philip, J., Babinot, J.F., Tronchetti, G., Fourcade, E., Guiraud, R., Bellion, Y., Herbin, J.P., Combes, P.J., Cornée, J.J., Dercourt, J., Ricou, L.E., 1993b. Late Cenomanian (94-92 Ma). In: Dercourt, J., Ricou, L.E., Vrielynck, B. (Eds.), Tethys Palaeoenvironmental Maps, Explanatory Notes. Gauthier-Villars, Paris, pp. 153-178.

Pigott, J., Neese, D., Geiger, C., 1995. Ogaden basin subsidence history: another key to the Red Sea-Gulf of Aden tectonic puzzle. Am. Assoc. Pet. Geol. Int. Conf. and Exhibition, Nice, 10-13 September 1995, Abstract, p. 57A.

Piqué, A., 2001. Geology of Northwest Africa. Translator: Carpenter, M.S.N., Beitäge zur regionalen Geologic der Erde, Band 29, Gebr. Borntraeger edit., Berlin, Stuttgart, $310 \mathrm{p}$

Piqué, A., Tricart, P., Guiraud, R., Laville, E., Bouaziz, S., Amrhar, M., Ait Ouali, R., 2002. The Mesozoic-Cenozoic Atlas belt (North Africa): an overview. Geodinam. Acta 15, 185-208.

Pletsch, T., Erbacher, J., Holbourn, A.E.L., Kuhnt, W., Moullade, M., Oboh-Ikuenobede, F.E., Söding, E., Wagner, T., 2001. Cretaceous separation of Africa and South America; the view from the West African margin (ODP Leg 159). J. African Earth Sci. 14, 147-174.

Rabinowitz, P.D., Coffin, M.F., Falvey, D., 1983. The separation of Madagascar and Africa. Science 220, 67-69. 
Rabu, D., Nehlig, P., Roger, J., et al., 1993. Stratigraphy and structure of the Oman Mountains. Doc. B.R.G.M. 221, 262 p.

Ricou, L.-E., 1994. Tethys reconstructed: plates, continental fragments and their boundaries since $260 \mathrm{Ma}$ from Central America to Southeastern Asia. Geodinam. Acta 7, 169-218.

Robertson, A.H.F., Dixon, J.E., Brown, S., Collins, A., Morris, A., Pickett, E., Sharp, I., Ustaömer, T., 1996. Alternative tectonic models for the Late Palaeozoic-Early Tertiary development of Tethys in the Eastern Mediterranean region. In: Morris, A., Tarling, D.H. (Eds.), Palaeomagnetism and Tectonics of the Mediterranean Region, Geological Society, London, Special Publication 105, pp. 239-263.

Rouchy, J.M., 1981. La genèse des évaporites messiniennes de Méditerranée. Thesis Sci., University Paris 6, 395 p.

Sager, W.W., Koppers, A.A.P., 2000. Late Cretaceous polar wander of the Pacific plate: evidence of a rapid true polar wander event. Science 287, 455-459.

Sahabi, M., Olivet, J.-L., Aslanian, D., 2004. Un nouveau point de départ pour l'histoire de l'Atlantique central. CR Geosci. 336, 10411052.

Said, R., 1981. The geological evolution of the river Nile. Springer-Verlag, Berlin, $151 \mathrm{p}$.

Saint-Marc, P., N'Da, V., 1997. Biostratigraphie et paléoenvironnements des dépots crétacés au large d'Abidjan (Golfe de Guinée). Cretaceous Res. 19, 545-565.

Salel, J.F., Séguret, M., 1994. Late Cretaceous to Palaeogene thin-skinned tectonics of the Palmyrides belt (Syria). Tectonophysics 234, 265290.

Schandelmeier, H., Reynolds, P.O., 1997. Palaeogeographic-Palaeotectonic Atlas of North-Eastern Africa, Arabia and Adjacent Areas. Balkema, Rotterdam, pp. 1-160, 17 plates.

Schlumberger-Sonatrach, 1995. Conférence sur l'évaluation des puits/Well evaluation Conference, Algérie, 1995, Schlumberger, Chester-Bath, $390 \mathrm{p}$.

Schneider, J.L., Wolff, J.P., 1992. Carte géologique et cartes hydrogéologiques à $1 / 1.500 .000$ de la République du Tchad. Mémoire explicatif. Documents du BRGM 209, Orléans, 2 vol.

Schull, T.J., 1988. Rift basins of interior Sudan: petroleum exploration and discovery. Bull. Amer. Assoc. Petrol. Geol. 72, 11281142.

Semtner, A.K., Reynolds, P.O., Schandelmeier, H., Klitzsch, E., 1997. The Early Silurian (Llandovery, ca. $435 \mathrm{Ma}$ ). In: Schandelmeier, H., Reynolds, P.O. (Eds.), Palaeogeographic-Palaeotectonic Atlas of North-Eastern Africa, Arabia, and Adjacent Areas. Balkema, Rotterdam, pp. 21-23.

Sengör, A.M.C., 1990. A new model for the late Palaeozoic-Mesozoic tectonic evolution of Iran and implications for Oman. In: Robertson, A.H.F., Searle, M.P., Ries, A.C. (Eds.), The Geology and Tectonics of the Oman Region, Geological Society, London, Special Publication 49, pp. 797-831.

Shone, R., Booth, P., this issue. The Cape Basin, South Africa: A review. J. African Earth Sci. doi:10.1016/j.jafrearsci.2005.07.013.

Soulaimani, A., Le Corre, C., Farazdaq, R., 1997. Déformation hercynienne et relation socle/couverture dans le domaine du Bas-Drâa (AntiAtlas occidental, Maroc). J. African Earth Sci. 24, 221-284.

Stampfli, G.M., Borel, G.D., 2002. A plate tectonic model for the Paleozoic and Mesozoic constrained by dynamic plate boundaries and restored synthetic oceanic isochrons. Earth Planet. Sci. Lett. 196, 1733.

Stampfli, G.M., Mosar, J., Favre, P., Pillevuit, A., Vannay, J.-C., 2001. Permo-Mesozoic evolution of the western Tethys realm: the NeoTethys East Mediterranean Basin connection. In: P.A. Ziegler, W. Cavazza, A.H.F. Robertson, and S. Crasquin-Soleau (Eds.), PeriTethys Memoir 6: Peri-Tethyan Rift/Wrench Basins and Passive Margins, Mémoires du Muséum national d'Histoire naturelle de Paris 186, pp. $51-108$.

Stampfli, G.M., Borel, G.D., Marchant, R., Mosar, J., 2002. Western Alps geological constraints on western Tethyan reconstructions. J. Virtual Explorer 8, 77-106.
Stump, T.E., Al-Hajri, S., Van der Eem, J.G.L.A., 1995. Geology and biostratigraphy of the Late Precambrian through Palaeozoic sediments of Saudi Arabia. Rev. Palaeobot. Palynol. 89, 5-17.

Tari, G., Molnar, J., Ashton, P., 2003. Examples of salt tectonics from West Africa: a comparative approach. Geological Society, London, Special Publication 207, pp. 85-101.

Thierry, J., et al. (40 co-authors), 2000. Late Sinemurian. In: Dercourt, J., Gaetani, M., et al. (Eds.), Atlas Peri-Tethys, Palaeogeographical maps. CCGM/CGMW, Paris: map 7.

Torsvik, T.H., 1988. Palaeozoic palaeogeography: a North Atlantic viewpoint, vol. 120. Geological Society of Sweden (G.F.F.), pp. 109 118.

Unrug, R., 1996. The assembly of Gondwanaland. Scientific results of IGCP Project 288, Gondwanaland sutures and mobile belts. Episodes $19,11-20$.

Vail, J.R., 1989. Ring complexes and related rocks in Africa. J. African Earth Sci. 8, 19-40.

Vially, R., Letouzey, J., Bernard, F., Haddadi, N., Desforges, G., Askri, H., Boudjema, A., 1994. Basin inversion along the North African margin: The Saharan Atlas (Algeria). In: Roure, F. (Ed.), Peri-Tethyan platforms. Technip, Paris, pp. 79-118.

Vila, J.M., Feinberg, H., Lahondère, J.-C., Gourinard, Y., Chouabbi, A., Magné, J., Durand-Delga, M., 1995. Le chenal gréseux de l'Oligocène terminal et le Miocène de Sidi Affif dans leur cadre structural estalgérien: Origine saharienne du Numidien et calendrier des charriages miocènes. CR Acad. Sci. Paris 320, 1001-1009.

Villeneuve, M., this issue. Paleozoic basins of West Africa and the Mauritanides fold belt. J. African Earth Sci., doi:10.1016/ j.jafrearsci.2005.07.012.

Villeneuve, M., Cornée, J.J., 1994. Structure, evolution and palaeography of the West African craton and bordering belts during Neoproterozoic. Precambrian Res. 69, 307-326.

Watchorn, F., Nichols, G.J., Bosence, D.W.J., 1998. Rift-related sedimentation and stratigraphy, southern Yemen (Gulf of Aden). In: Purser, B.H., Bosence, D.W.J. (Eds.), Sedimentation and Tectonics of Rift Basins: Red Sea-Gulf of Aden. Chapman and Hall, London, pp. $165-189$.

Wennekers, J.H.N., Wallace, F.K., Abugares, Y.I., 1996. The geology and hydrocarbons of the Sirt Basin: a synopsis. In: Salem, M.J., Mouzughi, A.J., Hammuda, O.S. (Eds.), The Geology of Sirt Basin: First Symposium on the Sedimentary Basins of Libya, Tripoli, 10-13 October 1993, vol. 1. Elsevier, Amsterdam, pp. 3-58.

Wildi, W., 1983. La chaîne tello-rifaine (Algérie, Maroc, Tunisie): Structure, stratigraphie et évolution du Trias au Miocène. Rev. Géogr. phys. Géol. dynam. 24, 201-297.

Wilson, M., Guiraud, R., 1992. Magmatism and rifting in Western and Central Africa, from Late Jurassic to Recent times. Tectonophysics 213, 203-225.

Wilson, M., Guiraud, R., 1998. Late Permian to Recent magmatic activity on the African-Arabian margin of Tethys. In: MacGregor, D.S., Moody, R.T.J., Clark-Lowes, D.D. (Eds.), Petroleum Geology of North Africa, Geological Society, London, Special Publication 132, pp. 231-263.

Winn Jr., R.D., Steinmetz, J.C., Kerekgyarto, W.L., 1993. Stratigraphy and rifting history of the Mesozoic-Cenozoic Anza Rift, Kenya. Amer. Assoc. Petrol. Geol. Bull. 77, 1989-2005.

Wycisk, P., 1991. Stratigraphic update of the nonmarine Cretaceous from SW Egypt and NW Sudan. Cretaceous Res. 12, 185-200.

Wycisk, P., Klitzsch, E., Jos, C., Reynolds, O., 1990. Intracratonal sequence development and structural control of Phanerozoic strata in Sudan. Berl. Geowiss. Abh., A 120, 45-86.

Ziegler, P.A., 1989. Evolution of Laurussia-A study in Late Palaeozoic Plate Tectonics. Kluwer Academic Publication, Dordrecht, 102 p.

Ziegler, P.A., 1990. Geological Atlas of Western and Central Europe, second ed. Shell Internationale Petroleum Mij. B.V. and Geological Society, London, 239 p.

Ziegler, M.A., 2001. Late Permian to Holocene paleofacies evolution of the Arabian plate and its hydrocarbon occurrences. GeoArabia 6, 504-665. 
Ziegler, P.A., Cloetingh, S., Van Wees, J.-D., 1995. Dynamics of intraplate compressional deformation: the Alpine foreland and other examples. Tectonophysics 252, 7-59.

Ziegler, P.A., Cloetingh, S., Guiraud, R., Stampfli, G.M., 2001. PeriTethyan Platforms: constraints on dynamics of rifting and basin inversion. In: P.A. Ziegler, W. Cavazza, A.H.F. Robertson, S. Crasquin-Soleau (Eds.), Peri-Tethys Memoir 6: Peri-Tethyan Rift/ Wrench Basins and Passive Margins. Mémoires du Muséum national d'Histoire naturelle de Paris 186, pp. 9-49. 